Journal of the Scientific Agricultural Society of Finland

Vol. 47: 71-137 1975

Maataloustieteellinen Aikakauskirja

\title{
A DYNAMIC MODEL FOR DETERMINING THE OPTIMUM CUTTING SCHEDULE OF ITALIAN RYEGRASS
}

Selostus: Dynaaminen malli Italian raiheinänurmen optiminiittoaikataulun määrittämiseksi

VELIPOH JONEN

Department of Plant Husbandry, University of Helsinki

TO BE PRESENTED, WITH THE PERMISSION OF THE Faculty of Agriculture and Forestry of the UNIVERSITY OF HELSINKI, FOR PUBLIC CRITICISM in Auditorium B5, VirkKi on June 9th, 1975, AT 12 o'CLOCK 


\section{Preface}

This study was carried out at the Department of Plant Husbandry, University of Helsinki. I owe a debt of gratitude to my teacher, Professor Juhani PaAtela, for the support he has given me in my work over a long period of time. I am also grateful to my colleague, Pertri Hari, Lic. Phil. who has passed on his intuitive ideas concerning the use of models in biological growth studies.

It is my pleasure to thank Professor Pekka Kilkki, Dr. Erkкi Kaukovirta, Dr. Erkki Kivi and Dr. Нгекка Suомela for checking my work and giving me constructive criticism. The manuscript was translated and revised by Mr. JонN Derome, B.Sc. to whom I express my thanks.

The field experiments were established at the Arctic Circle Experiment Station. I wish to thank Dr. Arvi Valmari and Mr. Reijo Heikkilä, M.Sc. for providing the facilities.

The study was supported by grants from the AUgust JoHAnnes and Arno TruRA Agricultural Foundation, the E. J. Sariola Foundation and the Academy of Finland. Finally, I am grateful to the Scientific Agricultural Society of Finland for including this study in their series of publication.

Helsinki April 1975 



\section{CONTENTS}

2. EXPERIMENTAL LEYS

3. RATE OF DEVELOPMENT OF ITALIAN RYEGRASS …........................ 80

3.1. Development rate and development stage …........................................ 80

3.2. Development rate experiment …........................................................ 84

3.2.1. Material .............................................................................. 84

3.2.2. Determination of development rate ........................................... 84

3.3. Dark respiration .......................................................................... 89

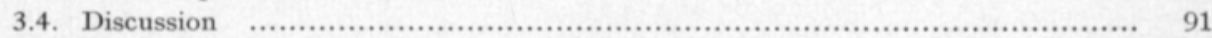

4. CROP GROWTH RATE OF ITALIAN RYEGRASS …................................. 94

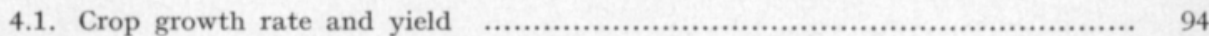

4.2. A dynamic model of crop growth rate ……....................................... 95

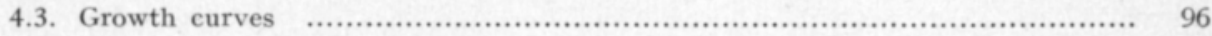

4.4. Crop growth rate experiments …..................................................... 99

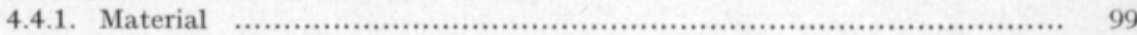

4.4.2. Calculation methods …................................................... 102

4.4.3. Results 1973 ................................................................... 103

4.4.4. Results 1974 ....................................................................... 106

4.4.5. Discussion ............................................................................ 108

4.5. Logistic growth curve and dynamic model of the crop growth rate ............ 110

5. OPTIMUM CUTTING SCHEDULE FOR ITALIAN RYEGRASS ................... 112

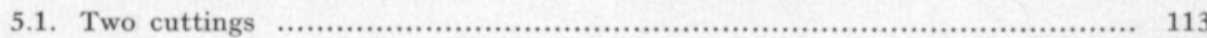

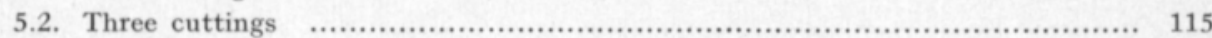

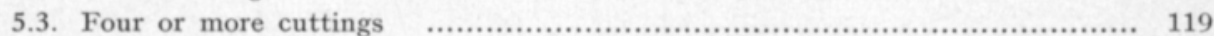

5.4. The maximization of the digestible (in vitro) dry-matter yield .................. 120

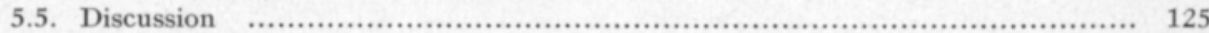

5.6. Towards the optimum cutting schedule of Italian ryegrass $\ldots \ldots \ldots \ldots \ldots \ldots \ldots \ldots \ldots .127$

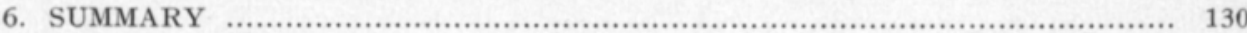

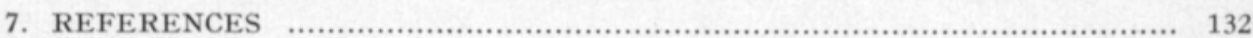

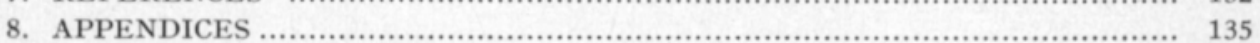

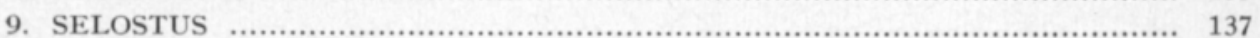





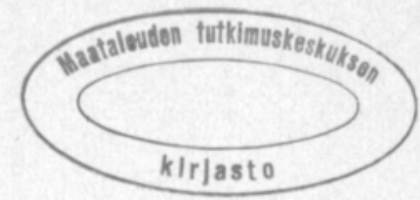

Pohjonen, V. 1975. A dynamic model for determining the optimum cutting schedule of Italian ryegrass. J. Scient. Agric. Soc. Finl. 47: 71-137.

\begin{abstract}
A quantitative approach to the determination of the optimum cutting schedule of Italian ryegrass (Lolium multiflorum Lam.) was presented. Optimization was based on a dynamic growth model which included the concepts crop growth rate, development rate and proper growth rate. The proper grwoth rate measured the growth potential associated with the stages of development in the sward.

The crop growth rate of Italian ryegrass was studied at the Arctic Circle Experiment Station during 1973 and 1974 . The proper growth rate was determined from primary observations as the derivative of an ordinary logistic curve which passes through origin. The maximum theoretical daily growth of Italian ryegrass was calculated as approx. $300 \mathrm{~kg} \cdot \mathrm{ha}^{-1} \cdot$ day $^{-1}$.

The optimum cutting schedules using gradient method were sought for Italian ryegrass sward. First, the maximum total dry-matter yield was looked for. Then the maximization was extended to the case, when the yield was weighted with the digestibility of the dry-matter. The maximum yield was obtained when the sward was cut three times, and when the cuttings were concentrated into the latter half of the growing season. The yield of the optimum cutting schedule was not sensitive to small changes in the cutting dates. In the conditions of Finnish Lapland the optimum cutting schedule of Italian ryegrass was: first cut at the end of July, second cut at the end of August and the third cut at the end of September.
\end{abstract}

\title{
1. Introduction
}

Apart from some abiotic and biotic environmental factors such as fertilization, the water balance of the soil and the density of the ley, the size and quality of the annual yield of sown grassland can also be affected by the dates chosen for cutting. The dates can be selected within the growing season for example so that dry-matter production is maintained at as high a level as possible. In order to ensure that as much as possible of the incoming radiation is bound during the growing season, the cutting dates should be arranged according to a specific plan (COOPER 1966).

The optimum cutting schedule for a silage ley can be defined as the choosing of cutting dates within the growing season such that the total yield obtained as the sum of the separate cuttings is maximised. For example, the total drymatter yield itself can be maximised. However, this is not sufficient since in grassland management another form of output is regarded as being more useful. For example it is possible to weight the dry-matter yield with the crude protein 
content. An even better method would be to use the digestibility of the drymatter since only that part of the dry-matter yield which is used in secondary production (by ruminants) is maximised. In practise, a farmer will also include costs; as far as he is concerned an optimum cutting schedule maximises the final result in economic terms.

The optimum cutting schedule varies from one growing season to the next since it is affected by the prevailing weather conditions. During an unfavourable summer the maximum possible total yield can be such that two cuttings suffice, but if the summer is favourable then three cuttings are required (cf. Mela 1974). For this reason, the optimum cutting schedule must to some extent be tied to the weather conditions. It has to be dynamic: the cutting dates must be flexible so that they can be changed as the growing season requires.

The main principle involved in the maximization of the total yield is that the cuttings are selected within the growing season such that the daily growth of the ley is maintained at as high a level as possible (COOPER and BreEse 1971). For example, the primary growth should not be cut at such an early stage of development that its growth potential is not exploited to the full, or at such a late stage of development that the growth potential has already fallen below that of the aftermath which follows the cutting.

The aim of this study is to approach the bases which can be used to determine the optimum cutting schedule for Italian ryegrass (Lolium multiflorum Lam.) growing under the agricultural conditions typical of southern Finnish Lapland. The scope of the study is restricted to leys which can be considered to be as non-varying as possible: fertilization, sowing quantity, variety etc. do not vary. Thus the cutting dates and the uncontrollable weather conditions are the only variables.

The study is divided into three parts. In the first part the determination of the development rate and stage of development of Italian ryegrass is studied. In the second part a dynamic model is constructed using these concepts for the quantification of the crop growth rate of Italian ryegrass. In the third part the model is used to determine the optimum cutting schedule of Italian ryegrass under field conditions. The total dry-matter yield is first maximised. Maximization is then extended to the case where the dry-matter is weighted with a factor which depends on the digestibility of the dry-matter. 


\section{Experimental leys}

The development and growth of Italian ryegrass was studied in 1973 and 1974 at the Arctic Circle Experiment Station, situated near Rovaniemi $\left(66^{\circ} 35^{\prime}\right.$ $\mathrm{N})$. The experimental leys were grown on a homogenous cultivated bog (Carex peat) drained by covered ditches. The $\mathrm{pH}\left(\mathrm{H}_{2} \mathrm{O}\right)$ of the peat in the experimental area was approx. 5; as regards nutrient status, it was better than that of the average type of peatland area under cultivation in the province of Lapland. The moisture conditions in the experimental leys were good except during a hot spell at the end of June and beginning of July 1973, which lasted for about two weeks.

Tetraploid Tetila Barenza varietý, developed in Holland (WIT 1958), was used in the study. This variety is marketed in Finland under the name Barmultra (RAIninko 1970). The leys were sown using a tractor seed drill (when the ground was firm enough to take a tractor), by hand or using a seed drill designed for use in small experiments (Planet Jr.). A sowing rate of $50 \mathrm{~kg} \cdot \mathrm{ha}^{-1}$ was used.

The leys were fertilized at levels higher than is normally used for perennial leys. According to the earlier experiences attained at the Arctic Circle Experiment Station the following basic fertilization was used: $1000 \mathrm{~kg} \cdot \mathrm{ha}^{-1}$ superphosphate $\left(87 \mathrm{~kg} \cdot \mathrm{ha}^{-1} \mathrm{P}\right)$ and $500 \mathrm{~kg} \cdot \mathrm{ha}^{-1}$ potassium chloride $\left(250 \mathrm{~kg} \cdot \mathrm{ha}^{-1} \mathrm{~K}\right.$.) Nitrogen fertilizer, $435 \mathrm{~kg} \cdot \mathrm{ha}^{-1}$ urea $\left(200 \mathrm{~kg} \cdot \mathrm{ha}^{-1} \mathrm{~N}\right)$, was applied to the primary growth after seedling emergence and again to the secondary growth after each cutting. Such a strong fertilization treatment was used partly because Italian ryegrass is better able to utilize fertilizers than perennial leys (cf. Schieblich 1956) and partly because as intensive level of development and growth as possible was required during the study period. 


\section{Rate of development of Italian ryegrass}

\subsection{Development rate and development stage}

During ontogeny of a plant a number of phenomena can be observed; for instance the sprouting of roots and shoots, the emergence of leaves, flowering and the formation of seeds, and the death of a mature individual (STREET and ÖPIK 1970, p. 209). Such phenomena are termed development stages. HARI (1968) presents the following quantitative definition for development stage:

$$
s(t)=\int_{0}^{t} M(X(t)) d t
$$

$\mathrm{He}$ calls the quantity s, the relative age of the plant or the physiological stage of development. Function $\mathrm{M}$ is the development rate of the plant, and describes the rate at which the development of an individual takes place. The development rate is dependant upon the state of the environment $\mathrm{X}=(\mathrm{x}$, $y, \ldots, z)$, which is represented by the temperature $(x)$, the intensity of incoming radiation $(\mathrm{y})$, soil moisture $(\mathrm{z})$ etc. The environmental state varies with time t, i.e. $X=X(t)$. It can be shown (HarI 1972), that both the chronological time (age) and the heat units accumulated during ontogeny are included in the physiological stage of development as special cases.

If the value of the physiological stage of development of the plant is known for each instant: $s=s(t)$, the development rate can be calculated as a time derivative of the development stage according to equation 3.1:

$$
M=\frac{d s}{d t}
$$

Concepts corresponding to the physiological stage of development have been used more recently, for example DeVelopment Stage, DVS (DE WIT et al. 1970, 1971) and "cycle interval in the annual cycle of development of forest trees" (SARVAS 1970, 1972). Kish et al. (1972) attempted to enlarge the heat unit theory by including soil moisture in the calculation. They were able to predict rather exactly the maturing of snap bean (Phaseolus vulgaris L.) using a new concept connecting temperature, soil moisture and time - SMGDH (soil moisture growing degree hours). Cross and Zuber (1972) and Mederski et al. (1973) for example have attempted to improve the ordinary heat unit calculation methods for predicting the flowering and maturing dates of maize (Zea mays L.). 
The development rate of plants growing in the temperate zone and under long day conditions is generally presumed to depend mainly on the temperature (e.g. UtaAker 1968, De Wit et al. 1970, Sarvas 1972). The moisture conditions in the soil must be high enough to enable the turgor pressure of the plant to be maintained. DE WIT et. al (1970) measured the development rate of oats (Avena sativa L.) and maize as a function of temperature (Fig. 1). The scale

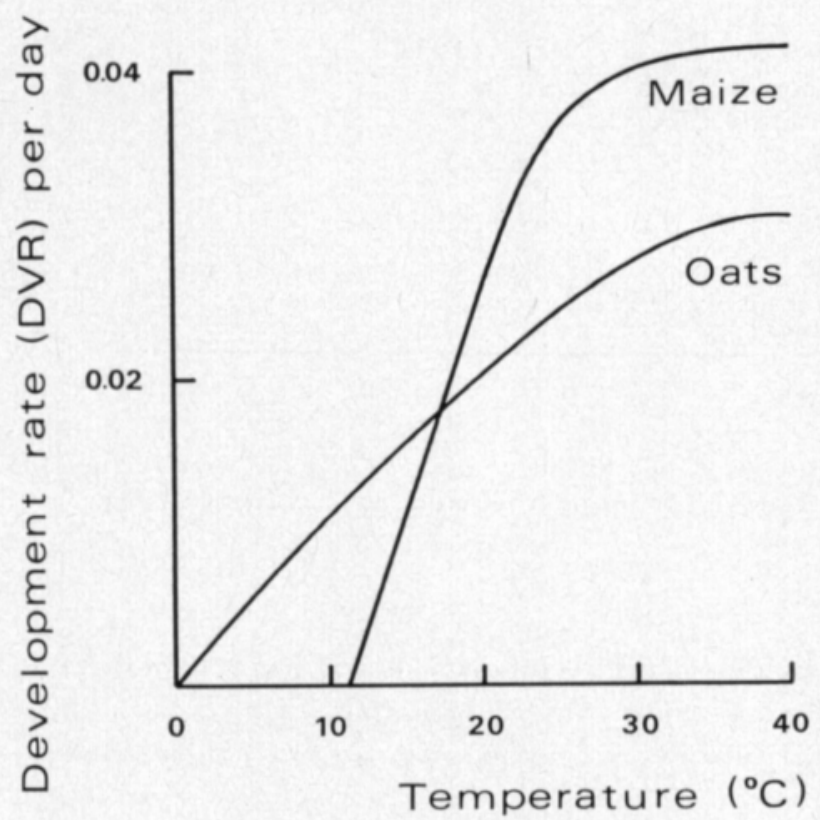

Fig. 1. The relationship between temperature and development rate of a maize and oat variety at a daylength of 14 hours (DE Wir et. al 1970).

of the development stage was chosen such that at the time of seedling emergece it has the value zero, and when the male flowers appeared it has the value one. The dimension of the development rate is thus expressed as units of day $^{-1}$.

SARVAS (1972) measured the development rate of some deciduous species during the "active period" (Fig. 2). He studied the duration of meiosis in aspen (Populus tremula L.) and the time taken for catkins to open in birch (Betula verrucosa Ehrh. and B. pubescens Ehrh.) at different constant temperatures. SARVAS expressed unit development rate using the concept - period units per hour (p.u./h.). It is defined such that the rate of progress of the active period is one unit per hour when the temperature remains constant at $5^{\circ} \mathrm{C}$.

DAHL and Mork (1959) observed that the daily height growth or Norway spruce (Picea abies (L.) Karst.) and the theoretical cumulative dark respiration, as measured in the laboratory, are strongly correlated with each other. HARI et al. (1970) used this observation and postulated that the dark respiration intensity of plants indicates as such the development rate. Dark respiration 


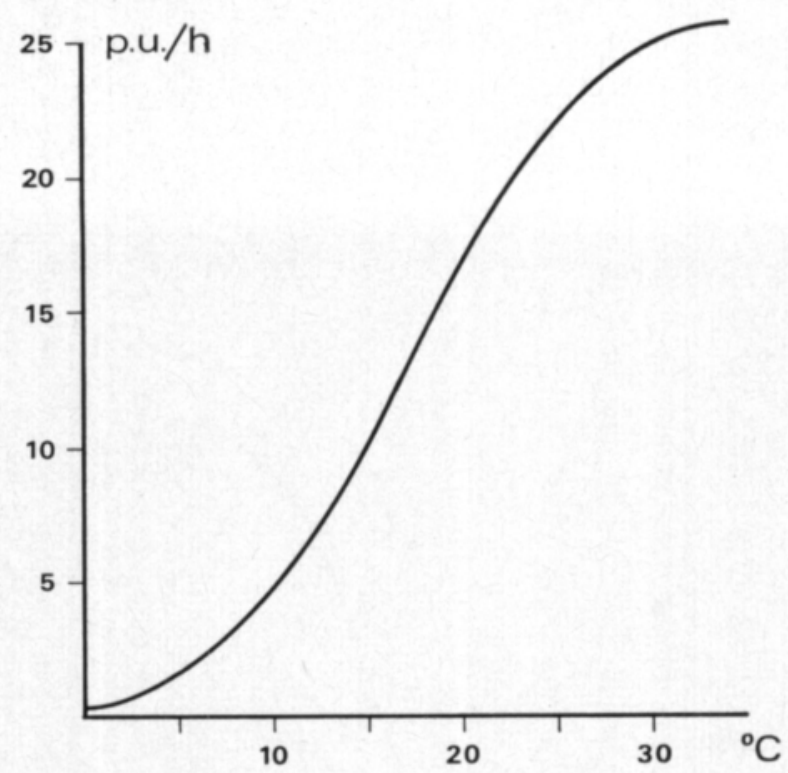

Fig. 2. Rate of progress of the active period of Populus tremula, Betula verrucosa and $B$. pubescens as a function of temperature, according to SARVAS (1972).

can be measured at constant temperature and thus the dependance of development rate on temperature can be estimated. The same assumption was also used by POHJONEN and HARI (1973) when studying the growth of the aftermath of Italian ryegrass. Unit dark respiration is a relative value only. Physiological development stage values calculated from it are thus relative values which lack any concrete descriptive ability.

The development rate can be calculated as a function of temperature from measurements carried out in a growth chamber under constant conditions as follows. Let us for example describe the development rate by means of the proceeding rate of mitosis. Mitosis starts at time $t_{1}$ and ceases at time $t_{2}$. The duration of mitosis $T$ is thus the chronological time interval $t_{2}-t_{1}$. Generally it is longer, the lower the temperature is (Fig. 3). Let us measure the duration of mitosis at different constant temperatures: $T=T(x)$. The physiological development stage at the start of mitosis is zero, and when mitosis ceases it is given the value one (see earlier). According to equation 3.1 , we can write

$$
1=\int_{t_{1}}^{t_{2}} M(x(t)) d t
$$

Since temperature does not change with time under constant conditions, equation 3.3 yields

$$
\begin{aligned}
& 1=\mathrm{M}(\mathrm{x}) \cdot\left(\mathrm{t}_{2}-\mathrm{t}_{1}\right) \text { or } \\
& 1=\mathrm{M}(\mathrm{x}) \cdot \mathrm{T}(\mathrm{x})
\end{aligned}
$$




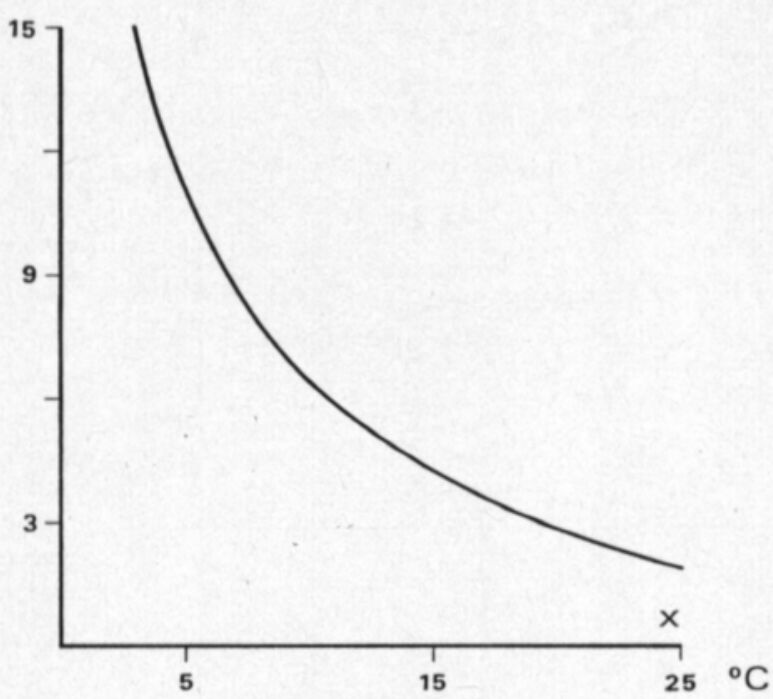

Fig. 3. The duration $(\mathrm{T}(\mathrm{x})$ hours) of the time interval between development stages at different constant temperatures. The duration of mitosis in Vicia faba L. is used as an example (Evans and SAvAge 1959).

The development rate $\mathrm{M}(\mathrm{x})$ can be solved from equation 3.4. It is a reciprocal function for the dependance between the measured duration of mitosis and the temperature:

$$
\mathrm{M}(\mathrm{x})=\frac{1}{\mathrm{~T}(\mathrm{x})}
$$

The method employing constant temperature conditions, used for the determination of development rate, is fast and simple. However, there are disadvantages. The assumption must be made that the results as such can be applied to natural conditions. In addition, it must be assumed that thermoperiodicity (WENT 1948) has no effect, i.e. the development rate is the same at constant temperatures as in corresponding variable temperature conditions. However, this does not always have to be the case since Evans (1963), for instance, observed that tomato plants (Solanum lycopersicum L.) grew better when the temperature was allowed to fluctuate by $\pm 2^{\circ} \mathrm{C}$ from constant temperature. Sugar beet (Beta vulgaris L.) and potato (Solanum tuberosum L.) have also been found to grow better when the temperature is varied (Monteith and ELson 1971).

Development rate measurements carried out in a growth chamber require rather complicated equipment which is usually lacking in most research institutes. In the following a method is presented for determining the development rate from field measurements. The assumptions mentioned above are not required, and the only instrument needed is a thermograph. 


\subsection{Development rate experiment}

\subsubsection{Material}

The primary growth of an Italian ryegrass sward was cut at 8 o'clock in the morning on a small area $(0.5 \mathrm{~m} \times 0.5 \mathrm{~m})$ leaving a $5 \mathrm{~cm}$ stubble (Fig. 4$)$. Fifty shoots were chosen from the stubble inside each plot, and then checked every morning at $\mathbf{8}$ o'clock to see how many of them had grown to a height of at least $10 \mathrm{~cm}$ from the cutting height. During the warm period in the middle of summer the shoots were also checked at 8 o'clock in the evening.

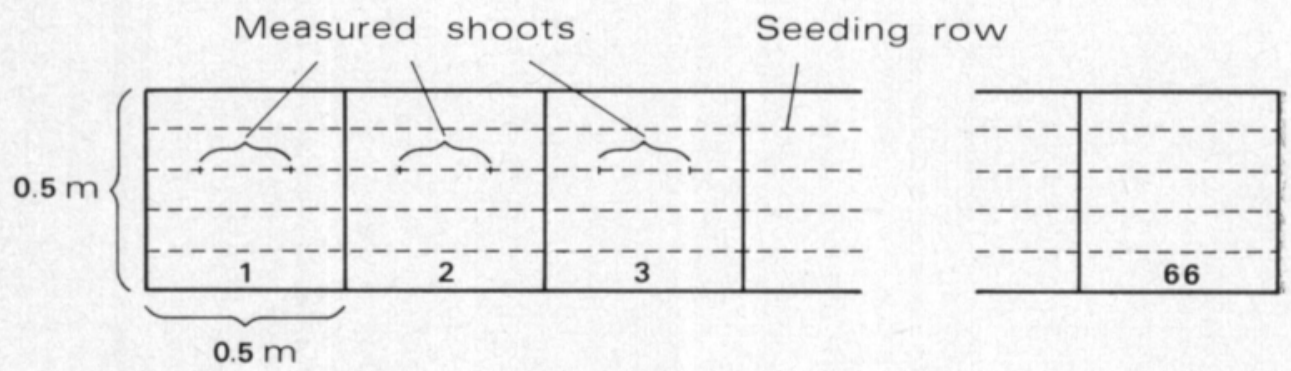

Fig. 4. Lay-out of the development rate experiment for Italian ryegrass.

The time, to within one hour, which each plot took from the cutting time up to the instant when half of the cut shoots had grown $10 \mathrm{~cm}$ from the cutting height, was calculated. Temperature was recorded on a thermograph, the probes being situated at a height of $25 \mathrm{~cm}$ above the ground. The temperature at hourly intervals was taken from the recording drum. The experiment commenced on 1973-06-26 and was terminated on 1973-09-25. Altogether 66 plots were used.

\subsubsection{Determination of development rate}

The abbreviations proposed by DE WIT et al. (1970) are used in this study. Thus DVR means DeVelopment Rate and DVS DeVelopment Stage. Let us assume that the development rate of Italian ryegrass is affected only by temperature, and that the development rate is represented by the speed at which the aftermath grows to a height of $10 \mathrm{~cm}$ from the cutting height. Let us first normalize the DVR so that it has the value 1.0 when the temperature is $10^{\circ}$ C, i.e. $\mathrm{M}(10)=1.0$ (cf. UtAAKER 1968). Subsequently the DVS of Italian ryegrass increases by one unit on those days when the temperature remains. constant at $10^{\circ} \mathrm{C}$ (Pohjonen and Hari 1973, cf. Cleary and Waring 1969).

The temperature dependance of the development rate can be examined starting with a linear example (Fig. 5), where no development takes place in the sward if the temperature is $\leq 5^{\circ} \mathrm{C}$, and where the development rate above $5^{\circ} \mathrm{C}$ is a linear function of temperature. The heat units used in Finland are calculated on this basis. 


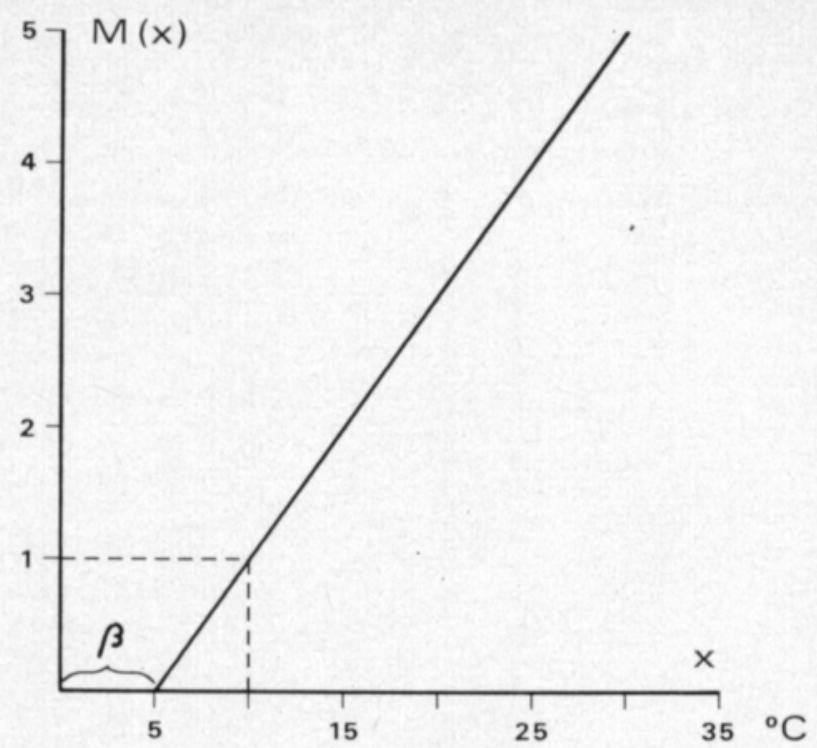

Fig. 5. Development rate as a linear function of temperature, threshold temperature $\beta=5^{\circ} \mathrm{C}$

Let us denote the threshold temperature by $\beta$. The development rate $\mathrm{M}(\mathrm{x})$ can be written in this linear case as follows:

$$
M(x)=\left\{\begin{array}{r}
0, \text { for } x \leq \beta \\
\frac{x-\beta}{10-\beta}, \text { for } x>\beta
\end{array}\right.
$$

If cutting takes place at the chronological time instant $t_{1}$ then at the instant $t_{2}$ half of the measured shoots will have grown $10 \mathrm{~cm}$ from the cutting height. The corresponding DVS values are zero at the cutting time, and S when $10 \mathrm{~cm}$ of growth have taken place. The duration $S_{i}$ of DVS for each plot $i$ ( $i=1,2$, $\ldots, 66$ ) can be calculated from equations 3.1 and 3.6 as follows (cf. Eq. 3.3):

$$
\mathrm{S}_{\mathrm{i}}=\int_{\mathrm{t}_{1}}^{\mathrm{t}_{2}} \frac{\mathrm{x}(\mathrm{t})-\beta}{10-\beta} d t
$$

When the threshold temperature is $5^{\circ} \mathrm{C}$, an exact value for the heat units used in Finland (owing to the normalization conditions used, the value is a relative one) can be calculated using equation 3.7.

If the graph for the development rate corresponds to the actual situation as shown in Fig. 5, then the same value of DVS should be obtained for each plot, i.e. $\mathrm{S}_{\mathrm{i}}$ is an invariant from one plot to another. As inaccuracies in the measurements and the heterogeneity of the soil, etc. introduce some variation in the material, $S_{i}$ varies from one plant to another. Thus if the graph for the development rate corresponds to the actual situation, then the values $S_{i}$ of DVS will be concentrated as closely as possible to each other. The variarion between them is thus minimised (cf. CRAMER 1945, p. 179) and the residual variation is not affected for example by the fact that the wrong threshold temperature has been chosen. This can be checked by choosing a new value for 
the threshold temperature and calculating once again the values of DVS for the plots. If the variation between these new values is smaller than that between the original values (Fig. 6), then the new threshold temperature (case 2 ) is obviously more correct from the biological point of view than the original one (case 1). The problem is to find the threshold temperature at which the variation between the DVS values $S_{i}$ of the plots is minimised.

\section{frequency}

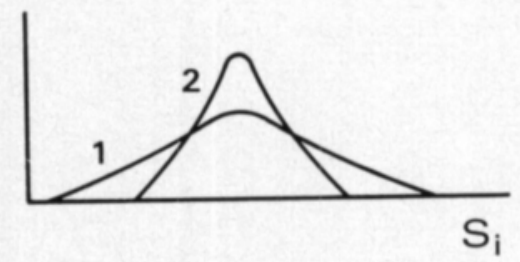

Fig. 6. Frequency distribution of the DVS values calculated at two different threshold temperatures. The variation in case 2 is smaller.

The effect of the threshold temperature was studied in the experimental material using the above-mentioned method. The variation was measured using a more concrete standard error of the mean. The integral of equation 3.7 was approximated by means of the following sum:

$$
\mathrm{S}_{\mathrm{i}}=\sum_{\mathrm{k}=1}^{\mathrm{n}} \frac{\mathrm{x}\left(\mathrm{t}_{\mathrm{k}}\right)-\beta}{10-\beta} \cdot 1 / 24
$$

where $x\left(t_{k}\right)$ is the $k: t h$ temperature reading taken from the thermograph paper when the time interval from $t_{1}$ to $t_{2}$ is divided into $n$ hourly parts. The value $1.699^{\circ} \mathrm{C}$ (Fig. 7) was found to be the best threshold temperature. The average

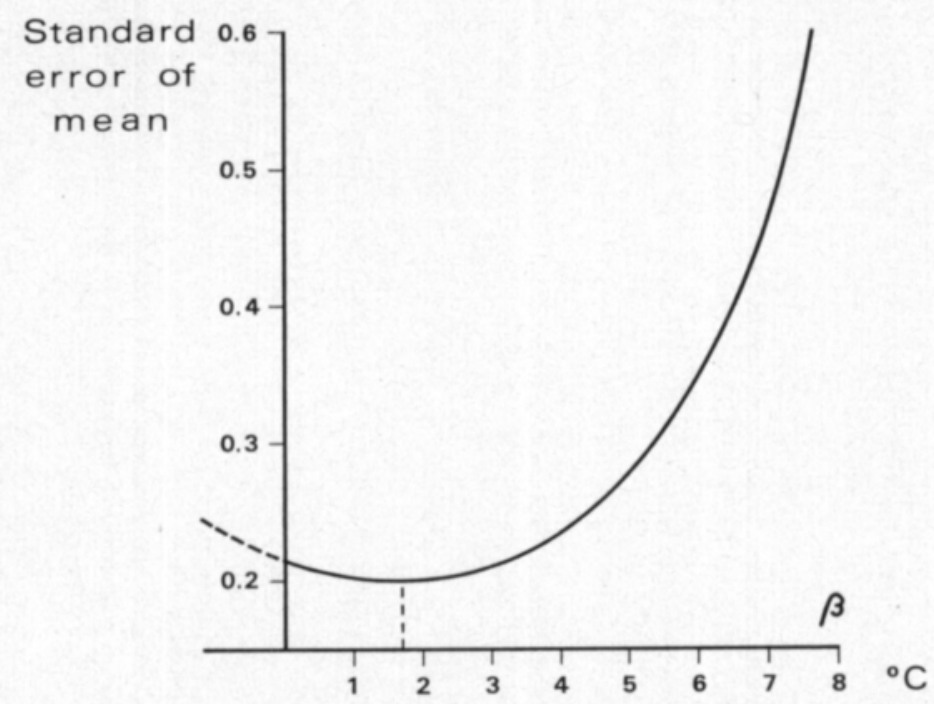

Fig. 7. Effect of threshold temperature $\beta$ on the standard error of mean $\mathrm{S}_{\mathrm{i}}$ (in units of DVS) in the development rate experiment for Italian ryegrass. 
duration of the stage in question was 7.246 units of DVS and the corresponding standard error of the mean was 0.203 units of DVS. Thus the aftermath of Italian ryegrass takes approximately one week to grow to a height of $10 \mathrm{~cm}$ after cutting has taken place, if the temperature remains around $10^{\circ} \mathrm{C}$.

Let us now consider the case where the development rate is an exponential function of temperature (Fig. 8). In this case, the equation for the development rate takes the form

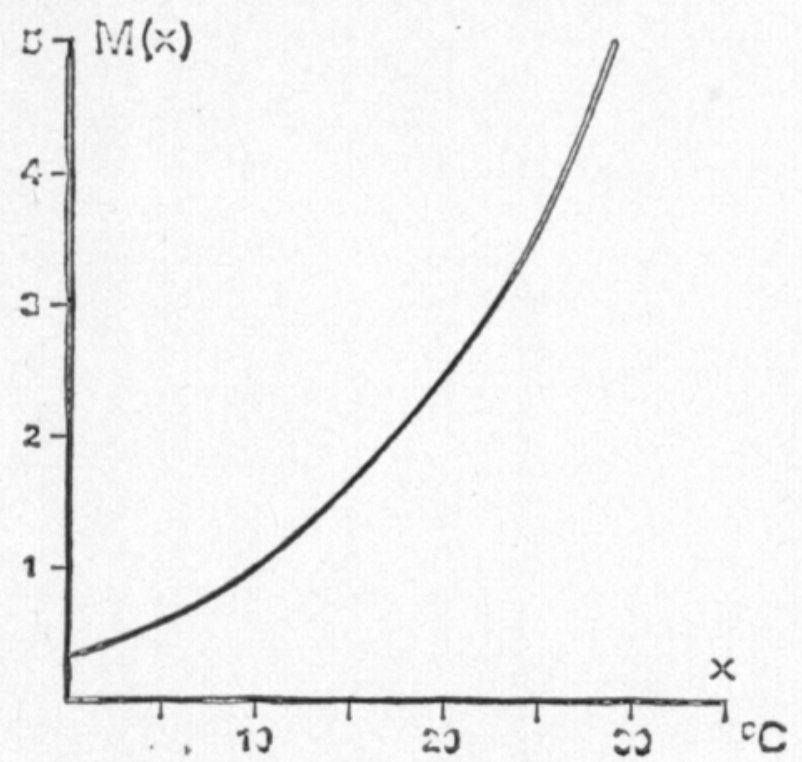

Fig. 8. Development rate as an exponential function of temperature.

$$
\mathbf{M}(\mathbf{x})=\mathrm{A}+\mathrm{B} \cdot \mathrm{e}^{\mathrm{C} \cdot \mathrm{x}}
$$

where $\mathrm{A}, \mathrm{B}$ and $\mathrm{C}$ are parameters. The curve must again pass through the point $(10,1)$ in order to satisfy equation 3.9 :

$$
1=\mathrm{A}+\mathrm{B} \cdot \mathrm{e}^{\mathrm{C} \cdot 10}
$$

Parameter $\mathrm{A}$ is solved from the equation 3.10 and put into equation 3.9:

$$
\begin{aligned}
& A=1-B \cdot e^{C \cdot 10} \\
& M(x)=1-B \cdot e^{C \cdot 10}+B \cdot e^{C \cdot x}
\end{aligned}
$$

Thus only two of the parameters, B and C, need to be estimated from the observations. They determine the more precise shape and positioning of the graph in the coordinate system.

The duration $\mathrm{S}_{\mathrm{i}}$ of DVS is calculated for the plots in the same way as earlier (cf. Eq. 3.7):

$$
S_{i}=\int_{t_{1}}^{t_{2}}\left(1-B \cdot e^{C \cdot 10}+B \cdot e^{C \cdot x(t)}\right) d t
$$


The problem in this case is to find the values of parameters $\mathrm{B}$ and $\mathrm{C}$ which minimise the variation between the DVS values $S_{i}$ of the plots. Computer iteration can be used to find an approximate solution by first trying the best values of $\mathrm{B}$ and then of $\mathrm{C}$. The integral of equation 3.12 is approximated using the sum (cf. Eq. 3.8). The following results were calculated from the test material:

$\begin{array}{cccc}\text { B } & \text { C } & \begin{array}{r}\text { mean for } \mathrm{S}_{i} \\ \text { units of }\end{array} & \begin{array}{c}\text { mean standard error } \\ \text { DVS }\end{array} \\ 0.727 & 0.0670 & 7.965 & 0.220\end{array}$

The mean standard error in the exponential case was greater $(0.220)$ than that in the best linear case (0.203). This indicates that the exponential relationship between the development rate and temperature is further from the actual situation from the biological point of view, than the linear relationship. In fig. 8 the graph of the exponential function has been drawn through the points determined by the best values of $\mathrm{B}$ and $\mathrm{C}$.

Let us now consider the case where the development rate and temperature have a logistic dependence on each other (Fig. 9) (cf. Fig. 2). The basic form of the logistic curve (e.g. STEWARd 1968, p. 430) is:

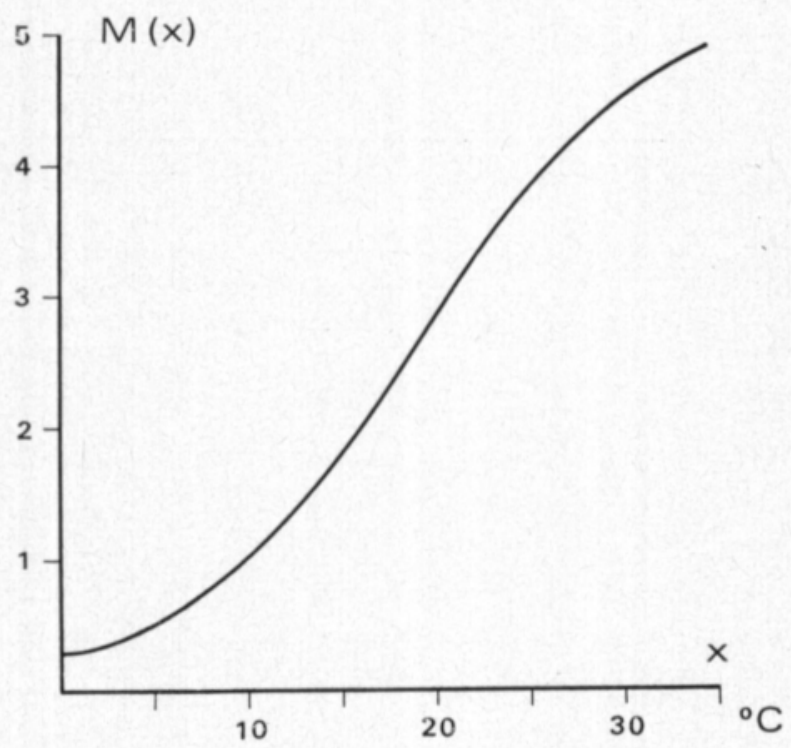

Fig. 9. Development rate as a logistic function of temperature.

$$
M(x)=\frac{A}{1+B \cdot e^{-C \cdot x}}
$$

Let us carry out a similar normalization on equation (3.13) as was done earlier. As before, there are two parameters, B and C, which have to be estimated from the observations:

$$
\mathrm{M}(\mathrm{x})=\frac{1+\mathrm{B} \cdot \mathrm{e}^{-\mathrm{C} \cdot 10}}{1+\mathrm{B} \cdot \mathrm{e}^{-\mathrm{C} \cdot \mathrm{x}}}
$$


Let us calculate the duration $\mathrm{S}_{\mathrm{i}}$ of DVS for the plots

$$
S_{i}=\int_{t_{1}}^{t_{2}} \frac{1+B \cdot e^{-C \cdot 10}}{1+B \cdot e^{-C \cdot x(t)}} d t
$$

Once again, the values of parameters $B$ and $C$ have to be found which minimise the variation between the DVS values $S_{i}$ of the plots. The following results were calculated from the test material using iteration:

$\begin{array}{cccc}\text { B } & \text { C } & \text { mean for } \mathrm{S}_{\mathrm{i}} & \begin{array}{c}\text { mean standard error } \\ \text { units of }\end{array} \\ \text { DVS }\end{array}$

The value for the mean standard error in the case of the logistic curve was smaller than that of any of the other cases. On the other hand, the duration of the average stage from the time of cutting to the time when the aftermath had grown $10 \mathrm{~cm}$ from the cutting height was the longest: 9.168 units of DVS.

In fig. 9 the graph of the logistic function has been drawn through the points determined by the best values of $B$ and $C$. This curve is used as the basis for the growth measurement studies presented later on. As an example, let us calculate using this curve the amount of daily DVS accumulated during the 1974 growth period of Italian ryegrass at the Arctic Circle Experiment Station. The amount of DVS accumulated by the $\mathrm{j}$ :th day is denoted by $r_{j}$. The value or $r_{j}$ can be obtained as follows:

$$
r_{j}=\int_{t_{j}}^{t_{j}+1}\left[\frac{1+19.625 \cdot e^{-0.15 \cdot 10}}{1+19.625 \cdot e^{-0.15 \cdot x(t)}}\right] d t
$$

The amounts of DVS accumulated daily are presented in Fig. 10. If the value of $r_{j}$ is approx. 1.0 (e.g. on 26.6) then it has been a cool day: i.e. the temperature has remained around the $10^{\circ} \mathrm{C}$ mark. On a warm day, (e.g. 10.7), Italian ryegrass has developed by an amount equivalent to that which would take place in approximately three days at $10^{\circ} \mathrm{C}$.

\subsection{Dark respiration}

The dark respiration of Italian ryegrass was measured in the laboratory of the Department of Silviculture, University of Helsinki. Five plants, approx. $25 \mathrm{~cm}$ high, were grown in plastic pot (approx. $20 \mathrm{~cm} \times 20 \mathrm{~cm}$ ). Fertilized peat (ST-400), watered at field capacity, was used as the substrate. The measuring equipment consisted of a growth chamber in which the temperature could be regulated between $5-35^{\circ} \mathrm{C}$, an infrared gas analyser (URAS 1) and a data logging system capable of recording the $\mathrm{CO}_{2}$ level and the temperature simultaneously at the measuring instant. Temperature was measured using a thermocouple.

The experimental measurements were carried out by placing the plants in a darkened growth chamber inside the cuvette. During the first period, which lasted for approx. $3 \mathrm{~min}$., air was drawn from outside the cuvette into the 


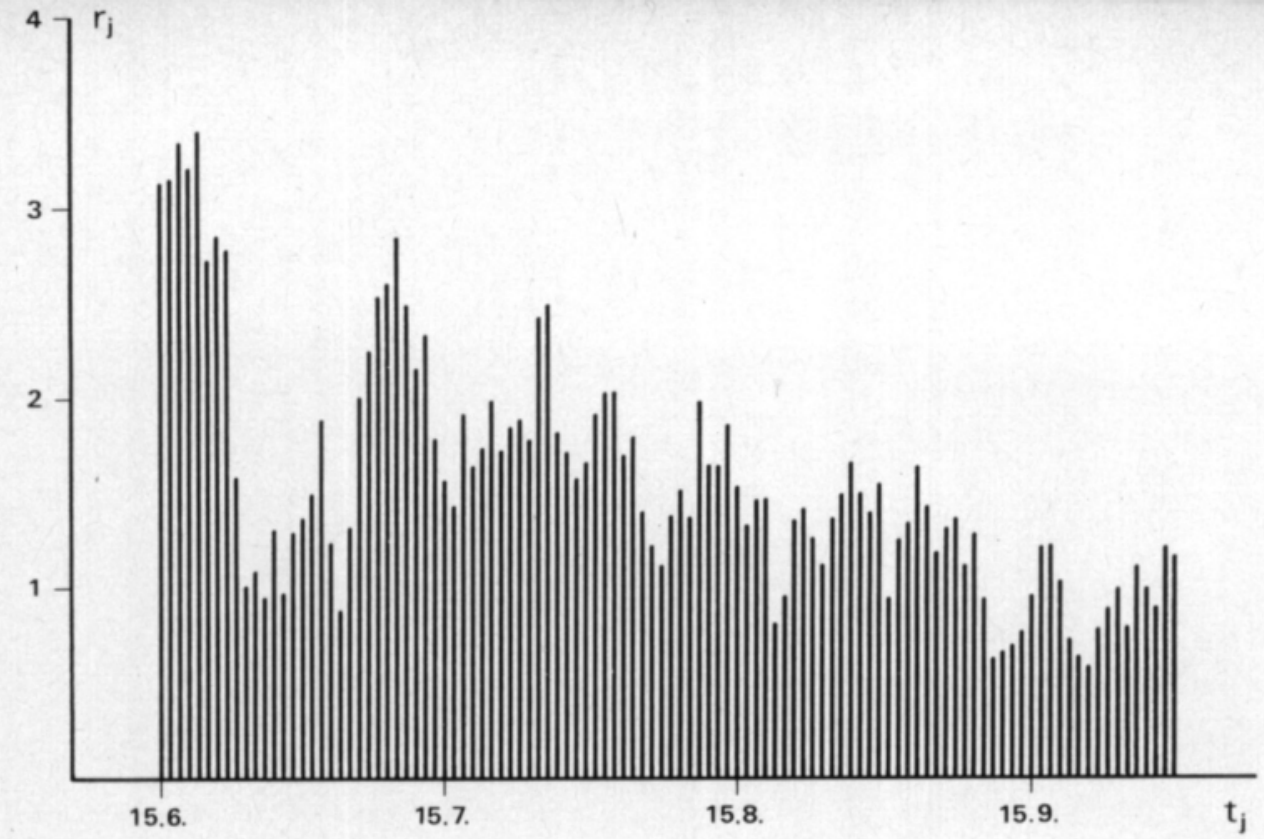

Fig. 10. Amounts of DVS accumulated daily in an Italian ryegrass sward at the Arctic Circle Experiment Station during the period 1974-06-15...09-30.

gas analyser. The difference in the $\mathrm{CO}_{2}$ level, i.e. between the inside and outside of the cuvette, indicated the intensity of dark respiration. In order to reveal any possible effect resulting from the weakening of the vigour of the plants during the measurement series, a series was performed in which the temperature was gradually raised and then lowered again. However, no adverse effect was observed. On the other hand, some delay in the reaction of the plants to temperature did cause some inaccuracies in the results.

The intensity of dark respiration was obtained from the measurements as a function of temperature in millivolt values. (Fig. 11). The actual intensity $\left(\mathrm{mg} \cdot \mathrm{h}^{-1} \mathrm{CO}_{2}\right)$ was not calculated.

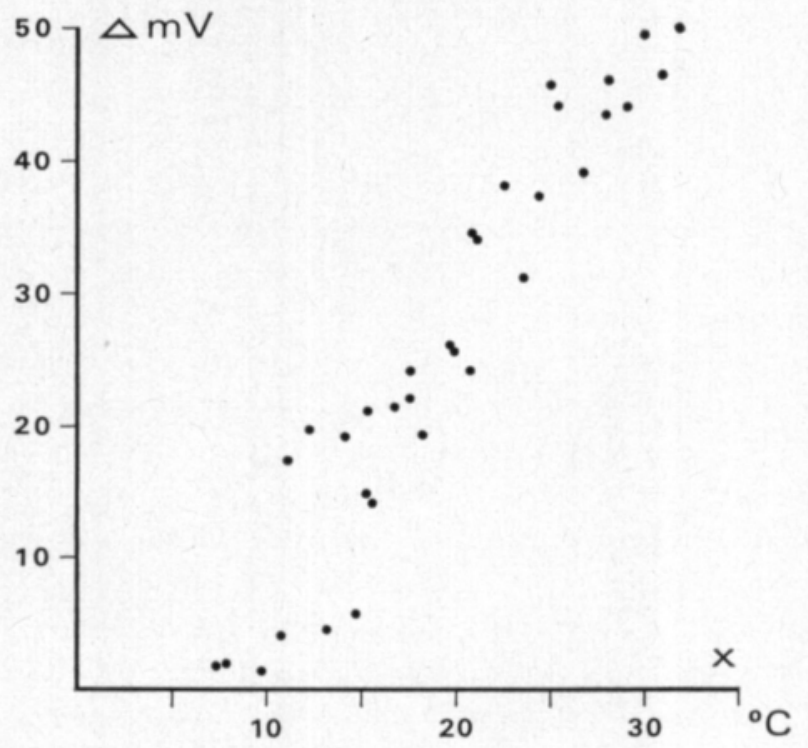

Fig. 11. Dark respiration of Italian ryegrass as a function of temperature. The points are primary observations. 


\subsection{Discussion}

It was assumed in the study that the development rate of an Italian ryegrass sward is described by the rate at which the aftermath grows $10 \mathrm{~cm}$ from the cutting height, and that only temperature has an effect on this rate. This is obviously an oversimplification since the size of the root network at the cutting time probably has some effect. Such an effect would be smaller at the beginning of the experiment than at the end. There are differences between successive days which may have an effect on the amount of soluble carbohydrates in the roots at the cutting moment (cf. Davidson and Milthorpe 1965). The development rate is also dependant upon the day length (DE WiT et al. 1970, HARI and Siren 1972, Williams 1974), which in this case varied during the experimental series. Since such sources of error are involved, the calculated estimate for the development rate should only be regarded as a mean value graph for the development rate of the aftermath of Italian ryegrass throughout the whole summer. Presumably it can also be used as a value graph for the development rate of the primary growth and also in growth studies to be presented later on where growth is described under corresponding conditions. Extrapolation of these results to other conditions should only be done with great care.

The measuring method for development rate was not sound from the conceptual point of view in this study, it was merely assumed that the abovementioned rate could be used to describe it. The more correct method on theoretical grounds would be to observe actual development stages such as seedling emergence and flowering (cf. DE WIT et ai. 1970). However, the time intervals between these stages could not be used since, under the conditions prevailing in Lapland, ear formation of tetraploid Italian ryegrass is uncertain. The calculation method presented in this study is also suitable for use in analysis concerning time intervals between such stages.

The dark respiration of Italian ryegrass, measured in the laboratory as a function of temperature was roughly the same as that obtained for the graph of the development rate calculated from the results of the field experiment. The only differences occurred at low temperatures. This may be caused by the fact that an adequate number of measurements of the intensity of dark respiration was not carried out at low temperatures. The temperature of the growth chamber used in the experiment could not be lowered to below $5^{\circ} \mathrm{C}$. The similar dependance of the dark respiration and the development rate on temperature supports the hypothesis which states that dark respiration activity and growth processes should be associated with each other in the growth model (e.g. Evans 1970, Hari et al. 1970, PohJonen and Hari 1973).

In the study, temperature recordings were made in a weather chamber. A more exact method would have been to measure the temperature continuosly in the stem apex which, in the case of the aftermath of Italian ryegrass, is situated approx. $1 \mathrm{~cm}$ below the ground surface. However, as the results are to be used to predict the development rate of a cultivated ley in practice, the measuring method must be developed in such a way that the temperature recorded in the weather chamber of a meteorological station can be used as the basis of the calculations. 
The logistic curve (Fig. 9.) which was found to be the best graph of the development rate closely resembles the curve (Fig. 2.) presented by SARvas (1972): for instance the inflexion point of both curves falls at approximately the same temperature, i.e. $17-18^{\circ} \mathrm{C}$. Sarvas presumes that the dependance which he has found can be widely applied to other tree species. Although the exact control of the dependance is obviously specific to the individual species as well as being a genetic property, it may be that the development rate reacts to temperature roughly according to the same graph in many temperate zone plants, both trees and grasses.

When studying the threshold temperature which is the basis for the heat sum, it was observed that the standard value $5^{\circ} \mathrm{C}$ used at the present time is weaker than lower temperatures. This is partly due to the fact that particularly during frosty nights in late summer, the temperature in the weather chamber was noticeably lower than the actual temperature in the stem apex. In point of fact however, the height growth of Italian ryegrass is clearly measurable when the temperature in the stem apex is below $5^{\circ} \mathrm{C}$, even though it is rather small.

Despite the obvious drawbacks involved in the calculation of the heat units, the concept has been used rather successfully since the days (1735) of De Reamur (Sarvas 1972). This is due to the fact that it was possible with a certain amount of luck, to approach the principle of the physiological clock of plants; it was possible to combine the interact:on between temperature and time in one measurable value. For this reason, the heat units and other related units should be considered to be measures of time. This individual physiological time of the plant is such that time dilation, in relation to the chronological time, takes place when the temperature is low, and contraction when the temperature is high.

It can perhaps be stated that the development stage used in the development rate experiments of Italian ryegrass is nothing more than the ordinary heat units which have been calculated more accurately and flexibly than earlier. The non-linear relationships which have been found can be approximated quite well using a straight line. However, for theoretical reasons the heat unit system is rather inprecise. For instance, the threshold temperature is difficult to justify on biological grounds. Moreover, it is difficult to expand the concept of heat units to cover other abiotic factors which affect the development rate such as day length (see earlier) and soil moisture (cf. KISH et al. 1972).

Although the heat unit system is associated with a number of drawbacks its use for measuring the development stages in practical cultivation is well justified in such areas where the development rate in mainly limited by temperature. Under these conditions, the heat units are sufficiently accurate and can be quickly calculated. In addition, under Finnish conditions a threshold temperature of $5^{\circ} \mathrm{C}$ is justified by the fact that the disappearance of the snow cover and the beginning of the growing season as calculated from the heat units happen to coincide with each other.

The measure of the development stage which can be calculated from the interaction of temperature and time can be interpreted as a special case of the 
more general time measure of $\mathrm{t} \mathrm{h}$ e $\mathrm{p} \mathrm{r}$ o $\mathrm{per} \mathrm{t}$ i m e of a plant. It is a measure which includes the interaction of chronological time and all the abiotic factors which affect the development rate. Such proper time can be calculated in principle using HarI's transformation (Eq. 3.1), although the quantitative information about the dependance of the development rate on the state of the environment is rather deficient. 


\section{Crop growth rate of Italian ryegrass}

\subsection{Crop growth rate and yield}

Let us denote the dry-matter yield per unit area of the sward by W. The crop growth rate CGR, at any instant in time t, is defined as the increase in the amount of dry-matter per unit of time (e.g. WATSON 1952).

$$
\mathrm{CGR}=\frac{\mathrm{dW}}{\mathrm{dt}}
$$

The concept crop growth rate is mathematically analogical with the concept development rate (cf. Eqs. 4.1 and 3.2). Correspondingly, the dry-matter yield of the sward can be calculated analogically with the development stage from the crop growth rate as follows (cf. Eq. 3.1):

$$
W(t)=\int_{0}^{t} \operatorname{CGR}(t) d t
$$

In order to determine the crop growth rate at any time instant, only the dependance $\mathrm{W}(\mathrm{t})$ between the dry-matter yield and time (Fig. 12a) need be known. This is the main difficulty involved in growth analysis (RADFORD 1967).

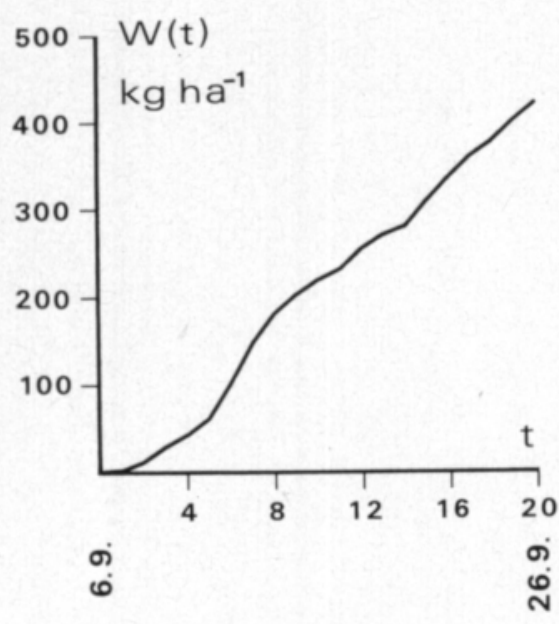

a

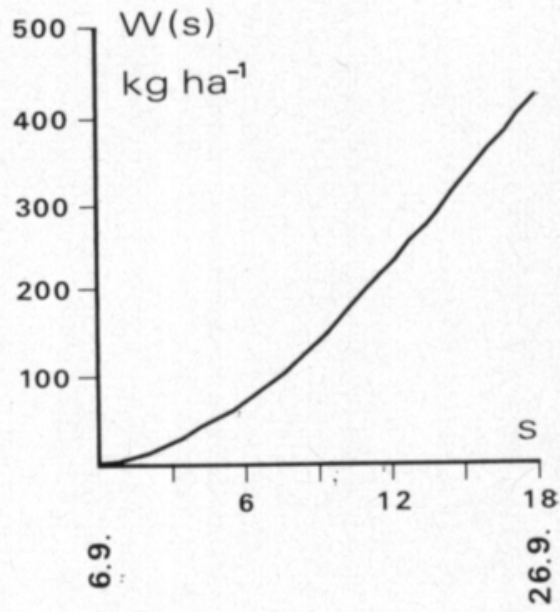

b

Fig. 12. The dependance of dry-matter yield (W) on chronological time (12a) and DVS (12b). Data from PoHJONEN and HARI (1973). 
In general it is very difficult to describe function $W(t)$ by means of a simple expression, like for instance $\mathrm{A}+\mathrm{Bt}+\mathrm{Ct}^{2}+\mathrm{Dt}^{3}$ (cf. Kornher 1971), since any irregularities (e.g. the kink in Fig. 12a) in the rate of biomass increase caused by alternate warm and cool periods are not taken into account.

The dry-matter yield can also be studied as a function of development stage of the sward: $W=W(s)$ (Fig. 12b). The use of DVS permits any variations which occur in the rate of biomass increase as a result of warm and cool periods, to be taken into account, by dilating and contracting the time axis according to the temperature conditions. For this reason, the observation points are more regularly placed in the coordinate system in Fig. 12b than in Fig. 12a. It can be assumed that the dependance W(s) is more easily depicted by means of a simple mathematical model than the dependance $W(t)$.

Let us define a new concept, the proper growth rate PGR as follows:

$$
P G R=\frac{d W}{d s}
$$

The proper growth rate thus expresses the increase in dry-matter yield per unit of DVS. The proper growth rate includes as a special case the crop growth rate (CGR), since if DVS and chronological time proceed at the same rate, $\mathrm{PGR}=\mathrm{CGR}$ (cf. chronological time as a special case of physiological stage of development p.80). If the proper growth rate is known, the dry-matter yield of the sward can be obtained by integration, for example at DVS instant $s_{1}$, as follows:

$$
W\left(s_{1}\right)=\int_{0}^{s_{1}} \operatorname{PGR}(s) d s
$$

\subsection{A dynamic model of crop growth rate}

After the genotype has determined a certain basic level, the crop growth rate (CGR) is the final result of the interaction of two variables. One variable is the environmental state (temperature, soil moisture etc.), variations in which sometimes produce steep growth differences between consecutive days. The other variable is called the internal state (Milthorre and Moorby 1974, p. 2) and it depends on the proceeding of each plant in its ontogeny through the vegetative and generative stages to the point where a new seed is formed. Each stage represents a certain potential by which a plant can grow in unit time under favourable conditions. The potential is small during the initial stage of development, reaches a maximum during the middle part of the vegetative stage and henceforth starts to decline until it reaches zero when a new seed is formed.

From the biological point of view, it seems logical to consider that the crop growth rate is a product of the internal state of the sward and the state of the environment:

$$
\mathrm{CGR}=(\text { internal state of the sward) } \cdot(\text { environmental state) (cf. HARI et al. 1970) }
$$

Provided that CGR is greater than nought the previous relationship can be put into quantitative form by means of the proper growth rate and the 
development rate as follows. The dry-matter yield is dependant on the development stage (Fig. 12b), i.e. $W=W(s)$. Furthermore, the development stage depends on the chronological time: $\mathrm{s}=\mathrm{s}(\mathrm{t}$ ) (Eq. 3.1). Accordingly the drymatter yield depends on the chronological time as follows: $\mathrm{W}=\mathrm{W}(\mathrm{s}(\mathrm{t}))$. Let us calculate the crop growth rate CGR according to its definition (p.94):

$$
\operatorname{CGR}=\frac{\mathrm{dW}(\mathrm{s}(\mathrm{t}))}{\mathrm{dt}}
$$

Using the chain rule for differention of composite functions, equation 4.6 yields

$$
\mathrm{CGR}=\frac{\mathrm{dW}}{\mathrm{ds}} \cdot \frac{\mathrm{ds}}{\mathrm{dt}}
$$

According to its definition, $\mathrm{dW} / \mathrm{ds}$ is the proper growth rate $\mathrm{PGR}$, and $\mathrm{ds} / \mathrm{dt}$ is the development rate $\mathrm{M}$ (Eq. 3.2), therefore

$$
\mathrm{CGR}=\mathrm{PGR} \cdot \mathrm{M}
$$

In equation 4.8, the development rate $M$ is calculated from the environmental state vector. The second factor, the proper growth rate PGR, can thus be interpreted as being the internal state of the sward. In this study, it can also be considered as measuring the growth potential connected to each development stage of Italian ryegrass. Variations in the proper growth rate at different stages of the development can also be called the growth rhythm.

Equation 4.8 characterises the growth model for Italian ryegrass. It can be considered to work in such a way that during short time intervals the proper growth rate and the development rate are constant and the crop growth rate is the product of the two. At the end of the time interval, the proper growth rate and the development rate attain new values for the following time interval. The development rate is determined on the basis of the environmental state at that particular instant. The proper growth rate changes according to the way in which the sward developed during the previous time interval since the development rate increased the development stage of the sward and this again has an effect on the proper growth rate. The growth model of Italian ryegrass is thus characteristically dynamic (cf. DE WIT and Brouwer 1968), because the environmental state affects both sides of Equation 4.8 and the chronological time itself is not sufficient as a variable for describing the crop growth rate.

\subsection{Growth curves}

The term growth curve means the cumulative graph which is obtained when the dry-matter yield is plotted against time (e.g. STEward 1968, p. 414). In general, growth curves can be appoximated by means of some simple model which is usually a mathematical function. When development stage is used as a measure of time, the resulting proper growth rate in a dynamic model of the crop growth rate of Italian ryegrass can be calculated from this function as a derivative with respect to DVS. 
One of the first and most simple growth curves used in growth analysis was an ordinary exponential curve (BLACKMAN 1919) (Fig. 13). If $W_{o}$ is the original weight of the seed, the weight of one plant individual at the development stage $\mathrm{s}$ can be calculated from the following:

$$
\mathbf{W}(\mathbf{s})=\mathbf{W}_{\mathrm{o}} \cdot \mathrm{e}^{\mathbf{R s}}
$$

Fig. 13. Exponential growth curve

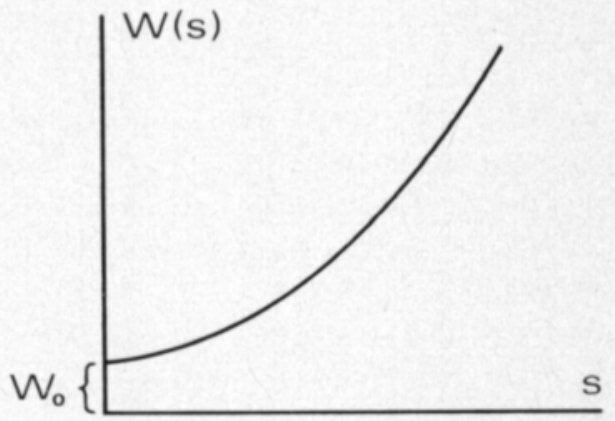

The parameter $R$ represents the efficiency of the plant to produce new biomass. The biomass of many biological systems follows an exponential growth curve especially during the initial stage of development. The exponential feature can be seen for example in Fig. 12b.

The biomass during the final stage of development no longer follows the exponential curve, but starts to approach some upper limit. The biomass and DVS thus follow overall an S-shape, the so-called sigmoid curve (cf. STREeT and ÖPIK 1970, p. 138) (Fig. 14).

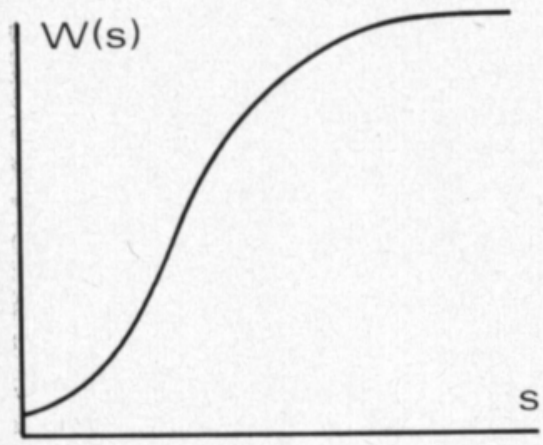

$\mathbf{a}$

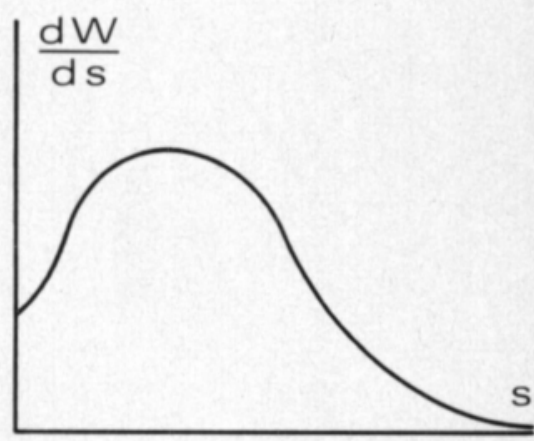

b

Fig. 14. Sigmoid growth curve (14a) and the proper growth rate calculated from it (14b).

In many cases, the properties of the sigmoid curve can be depicted by means of the so-called autocatalytic reaction equation:

$$
\frac{\mathrm{dW}}{\mathrm{ds}}=\frac{\mathrm{c}}{\mathrm{A}} \mathrm{W}(\mathrm{A}-\mathrm{W})
$$


where parameter $\mathrm{A}$ is the upper limit of the biomass. According to equation 4.10 , the proper growth rate increases during the initial stages of development almost directly proportionally to the biomass (exponential stage). In the final stages of development, the alleviation term $\mathrm{A}-\mathrm{W}$ (the portion missing from the final value of the biomass) begins to decrease the proper growth rate towards zero.

Equation 4.10 can be written in a more general form (c.f. Fletcher 1974):

$$
w^{\prime}+a w^{2}+b w=0,
$$

where $\mathrm{W}^{\prime}=\mathrm{dW} / \mathrm{ds}$. When development stage in equation 4.11 is substituted with chronological time, the solution $\mathrm{W}(\mathrm{t})$ can be called the logistic law (c.f. Eq. 3.13) (Verhulst 1838), the Pearl-Reed law (Pearl and Reed 1920), the autocatalytic law (see earlier) and the Robertson symmetric law (RoBERTSON 1929).

When $\mathrm{P}, \mathrm{Q}$ and $\mathrm{C}$ are chosen as the parameters, the logistic growth curve can be presented computationally in a simple form as follows (cf. Brougham and GLENDAY 1967):

$$
W(s)=\frac{1}{P+Q \cdot e^{-C \cdot s}}
$$

The dry-matter yield $\mathrm{W}(\mathrm{s})$ approaches the upper limit $\mathrm{P}^{-1}$, when $\mathrm{s} \rightarrow+\infty$ and the lower limit zero, when $s \rightarrow-\infty$ (Fig. 15)

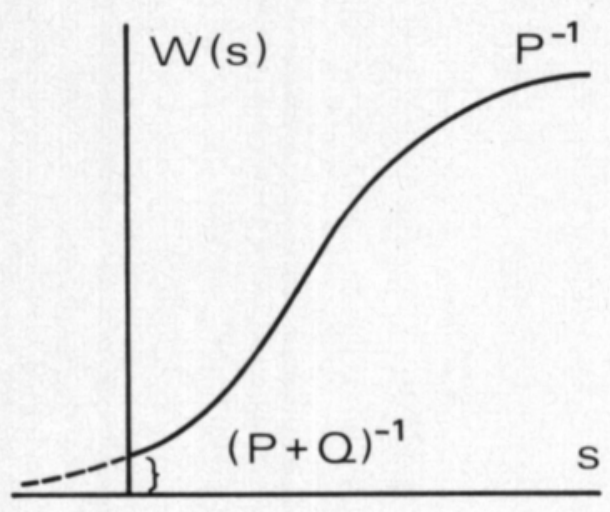

Fig. 15. Basic form of the logistic growth curve. (Eq. 4.12).

To be more precise the concept of dry-matter yield is defined in this study as being that part of the biomass of the sward of the existing Italian ryegrass sward which remains above the stubble height $(5 \mathrm{~cm})$. In addition, let us suppose that the DVS instant of the sward is zero when the sward is at the stubble height. Equation 4.12 in its present form is not suitable for this purpose since the curve should pass through the origin. This precondition is fulfilled if the curve in Fig. 15 is moved downwards by the amount $(P+Q)^{-1}$ (cf. Abrami 1972). Thus the equation for the logistic curve passing through the origin becomes

$$
W(s)=-\frac{1}{P+Q}+\frac{1}{P+Q \cdot e^{-C \cdot s}}
$$


The upper limit of the dry-matter yield is now $\mathrm{Q} \cdot \mathrm{P}^{-1}(\mathrm{P}+\mathrm{Q})^{-\mathbf{1}}$. Equation 4.13 can be rewritten in more general form (cf. Eq. 4.11)

$$
\mathrm{w}^{\prime}+\mathrm{aW}^{2}+\mathrm{bW}+\mathrm{w}^{\prime}(0)=0,
$$

which can be seen to be a more general form of the Verhulst's logistic law.

The proper growth rate is calculated from equation 4.13 by deriving it with respect to $\mathrm{s}$ :

$$
P G R=\frac{d W}{d s}=\frac{C \cdot Q \cdot e^{-C \cdot s}}{\left(P+Q \cdot e^{-C \cdot s}\right)^{2}}
$$

Some special values (Fig. 16) for the proper growth rate can be calculated from equation 4.15. The proper growth rate deviates from nought by the value $\alpha$, at the initial instant of DVS in the sward:

$$
\alpha=\operatorname{PGR}(0)=\frac{\mathrm{CQ}}{(\mathrm{P}+\mathrm{Q})^{2}}
$$

Fig. 16. Special values of the proper growth rate.

$\alpha=$ PGR at the zero instant of DVS

$\Omega=$ maximum value of PGR

$\mathrm{s}_{\mathrm{m}}=$ the instant of DVS corresponding to the maximum of PGR.

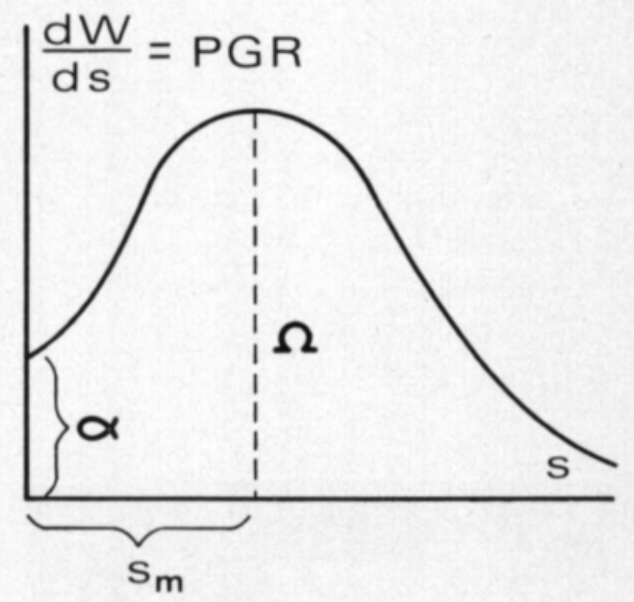

The proper growth rate reaches a maximum $\Omega$ at the DVS instant $\mathrm{s}_{\mathrm{m}}$

$$
\begin{gathered}
\Omega=\frac{\mathrm{C}}{4 \mathrm{P}} \\
\mathrm{s}_{\mathrm{m}}=\frac{\ln \mathrm{Q}-\ln \mathrm{P}}{\mathrm{C}}
\end{gathered}
$$

\subsection{Crop growth rate experiments}

\subsubsection{Material}

The crop growth rate of Italian ryegrass was studied at the Arctic Circle Experiment Station in Lapland during the 1973 and 1974 growing seasons. The dry-matter yield of the sward was followed in 1973 by means of height measurements and yield determinations. Six main plots were separated out in the Italian ryegrass sward, primary growth being measured in one of them and secondary growth in the rest (Fig. 17). 


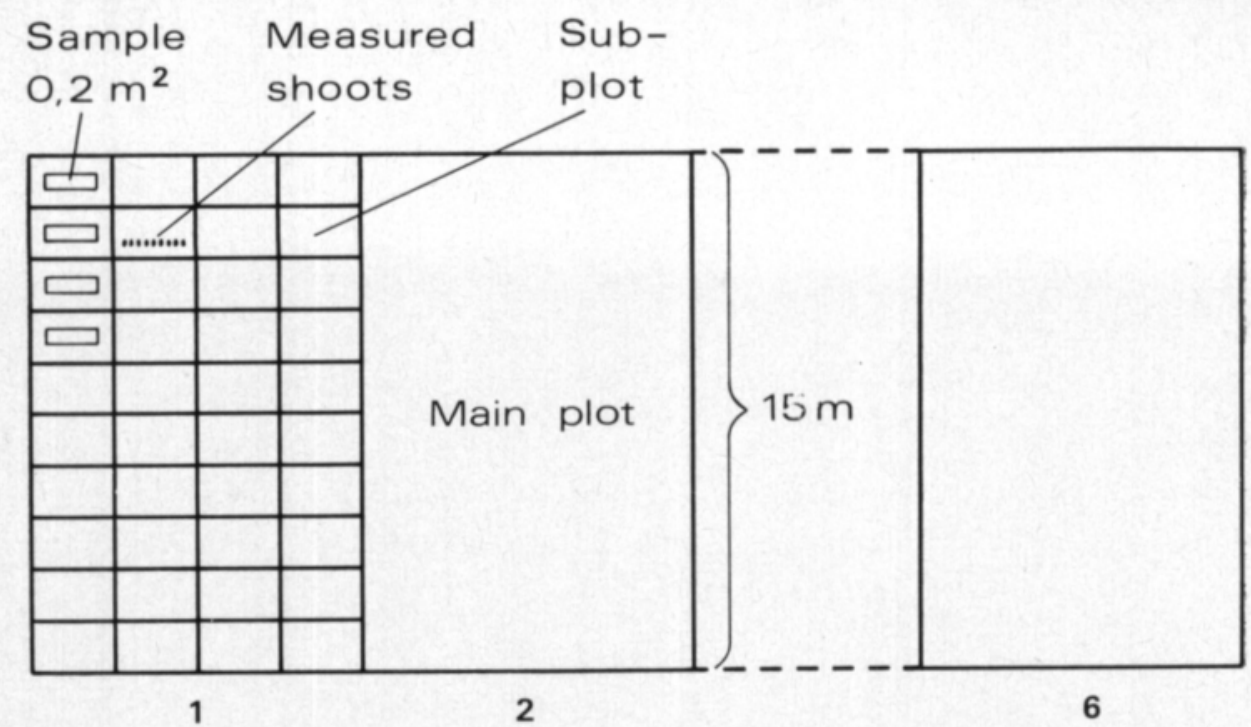

Fig. 17. Lay-out of the Italian ryegrass growth rate experiments carried out in 1973.

Of these six main plots, two were allowed to grow up from the stubble which was cut once and the four other ones from the stubble which was cut twice. Each main plot was divided up into 40 sub-plots, one being used for height measurements and the rest harvested as yield samples. The height of 23 selected plants was measured to the tip of the longest blade at 8 o'clock on the height measurement plot (Fig. 18).
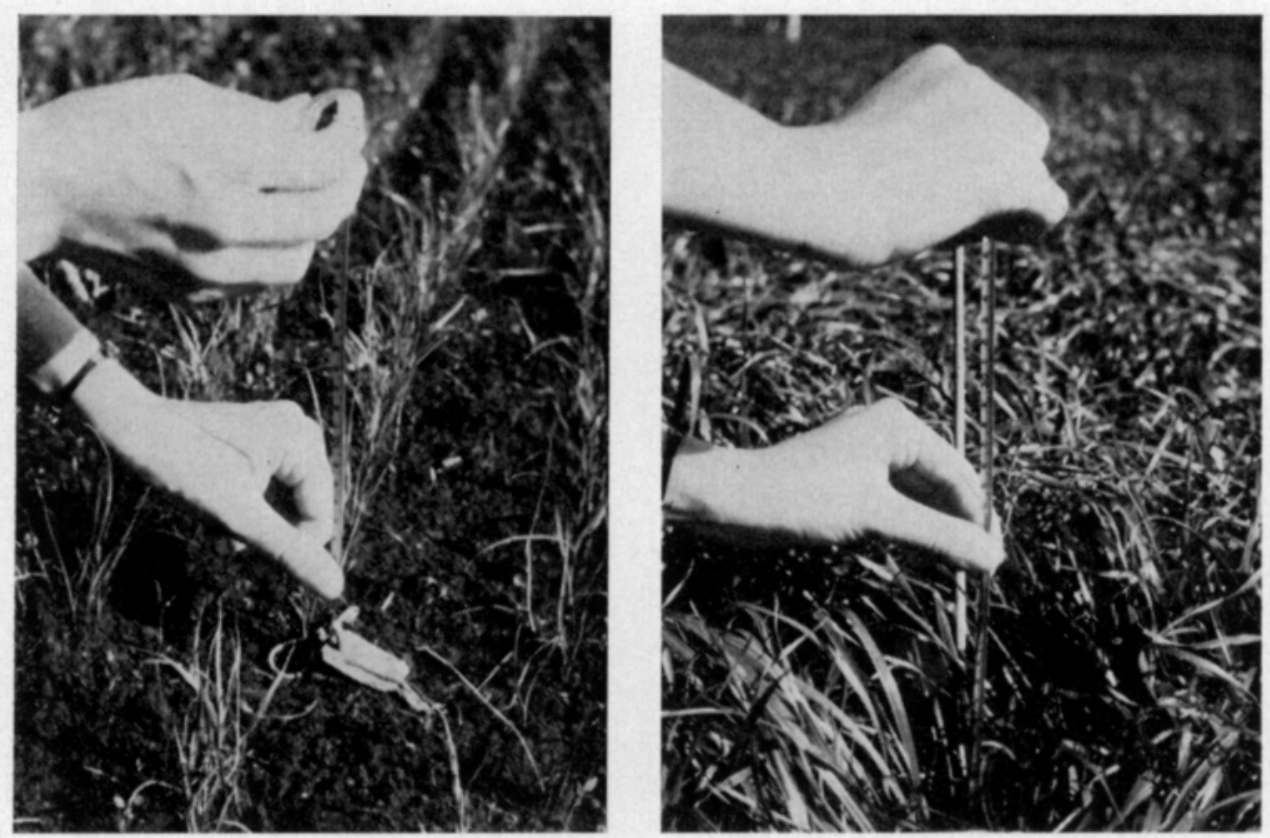

Fig. 18. Height measurement of Italian ryegrass. 18a: young primary growth, 18b: aftermath. 
Measurements were made to an accuracy of $1 \mathrm{~mm}$. Owing to the fact that in earlier measurements the blades of Italian ryegrass plants sometimes broke off at their tips, the daily height growth was regarded as the average of 20 of the largest height increments. Height measurement was started in the case of the primary growth when the shoots were about $5 \mathrm{~cm}$ high, and in the secondary growth the morning of the day following cutting. The height measurement series lasted in each of the main blocks for about 30 days.

While the height measurement series was taking place, yield samples were taken from the sward $2-3$ times a week. Four sub-plots were harvested at each sampling, a stubble about $5 \mathrm{~cm}$ high being left inside a $0.2 \mathrm{~m}^{2}$ sized frame (Fig. 19). The fresh and dry-matter yield for the block in question were determined from the samples.

Fig. 19. Determination of the yield of Italian ryegrass by means of the frame method.

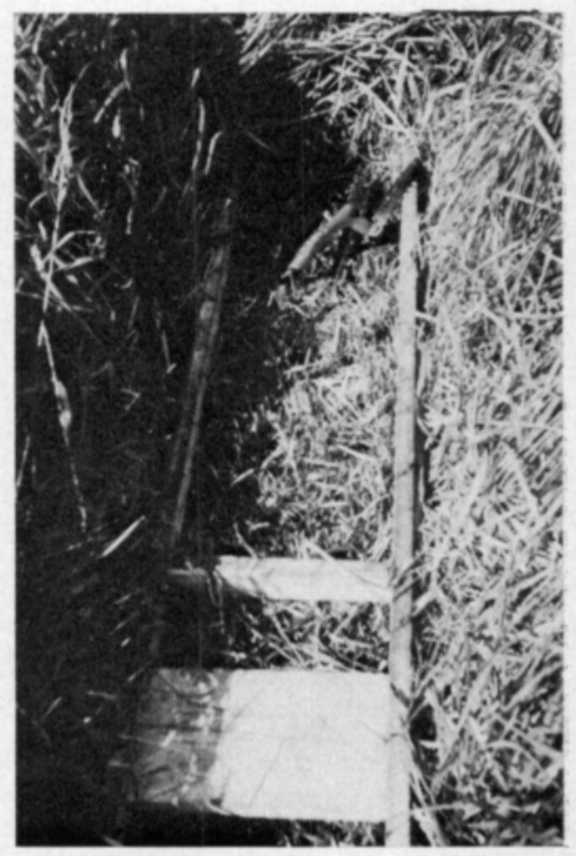

The dry-matter yield of the sward in 1974 was followed by taking yield samples only. In this case there were two primary growth swards, the first one was sown on 15.5, and the second on 7.6. The dry-matter yield of the aftermath resulting from cuttings carried out at five different times was also measured in the latter case (Fig. 20). Both of them grew from a stubble which had been cut only once. The dry-matter was determined on average five times a week using the same frame method as was used in 1973. Five replications were used in the initial stages of both of the series. However, during the final stage of the series the number of replications was reduced to two owing tothe increasing size and number of the samples.

In 1974, dry-matter yield samples were taken using a systematic sampling method: every day a new sample series was cut about $25 \mathrm{~cm}$ away from the previous sampling point. Systematic sampling was used because randomised 


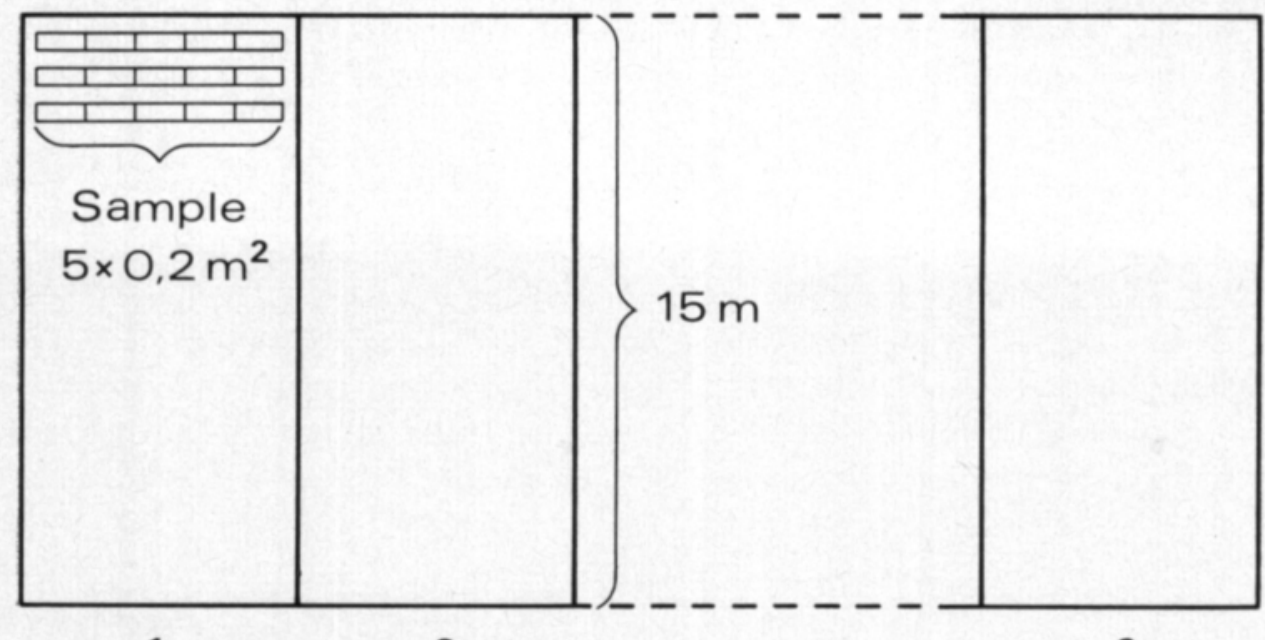

1

2

6

Fig. 20. Lay-out of the Italian ryegrass growth experiment in 1974, sward sown on 7.6.

sampling would require too large a measurement area owing to the trampling of the sward and the large numer of samples. For example, in the longest measurement series, samples were taken on $\mathbf{5 7}$ occasions.

\subsubsection{Calculation methods}

An exponential dependance caused by tillering exists between the height of the sward and the dry-matter yield. In this study the following equation was used:

$$
W=W(Q, C, h)=Q \cdot\left(e^{C \cdot h}-1\right)
$$

where $\mathrm{h}$ is the cumulative height increment of the measurement series counting from the start of the measurement series. Parameters $Q$ and $C$ were determined from the yield samples $W_{i}$ and their corresponding heights $h_{i}$ using the method of least squares (e.g. Deming 1948, cf. Appendix 1). In other words, the values of $\mathrm{Q}$ and $\mathrm{C}$ are sought which minimise the following sum of squares:

$$
\sum_{\mathrm{i}}\left(\mathrm{W}_{\mathrm{i}}-\mathrm{W}\left(\mathrm{Q}, \mathrm{C}, \mathrm{h}_{\mathrm{i}}\right)\right)^{2}
$$

The parameters of the logistic curve (Eq. 4.13) obtained by plotting the drymatter yield against DVS were determined using a method analogous with the previous one or a method of weighted fitting (cf. Deming 1948, p. 211, Brougham and Glenday 1967). From the yield sample data collected in 1974, three observations in the first primary growth and one observation in the first aftermath series were omitted from the fitting procedure because they were apparently biased (too large).

In order to fit the logistic curve, the initial instant in DVS in each sward should be known. It is natural to choose the cutting time of the previous sward as the initial instant (see earlier) in the aftermath sward. The initial instant 
in the primary growth is at the stage when the sward biomass starts to accumulate above the cutting height $(5 \mathrm{~cm})$. It is rather laborious to determine accurately this stage in practice since small irregularities in the soil surface affect the height of the stubble. In this study the initial instant of the primary growth was determined by plotting the observations in the coordinate system and estimating at what point the curve passed through the DVS axis (cf. RAulo and LEIKOLA 1974).

\subsubsection{Results 1973}

First, the curves for the relationship (Eq. 4.19) between the dry-matter yield of the sward and the cumulative height growth of the measuring point were fitted. The corresponding parameters and correlations between the calculated and observed values are presented in Table 1. The corresponding equation could not be calculated from the final measurement series because the abnormally cool weather conditions in autumn permitted only a small amount of growth to take place. The parameters of the penultimate series were used in the final series instead.

Table 1. The parameters of the equation (Eq. 4.19) for the relationship between the dry-matter yield of the sward and the cumulative height growth of the measuring point, and the correlations between the calculated and observed values in the 1973 measurement series. $\mathrm{p}=$ primary growth, $\mathrm{s}=$ secondary growth.

\begin{tabular}{|c|c|c|c|c|c|}
\hline Cutting & series & Period & $\mathrm{Q}$ & $\mathrm{P}$ & $\mathbf{r}$ \\
\hline $1 \mathrm{p}$ & .......... & 73-06-06 . . 07-19 & 141.0 & 0.0736 & 0.968 \\
\hline $2 \mathrm{~s}$ & 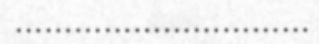 & 73-07-05 . 08-02 & 2480.0 & 0.0192 & 0.996 \\
\hline $3 \mathrm{~s}$ & 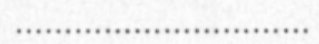 & $73-07-20 \ldots 08-16$ & 527.0 & 0.0445 & 0.987 \\
\hline $4 \mathrm{~s}$ & 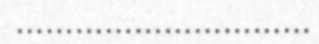 & $73-08-01 \ldots 08-31$ & 483.0 & 0.0488 & 0.958 \\
\hline $5 \mathrm{~s}$ & 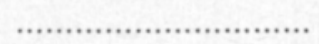 & 73-08-15 . .09-15 & 342.0 & 0.0850 & 0.955 \\
\hline $6 s$ & 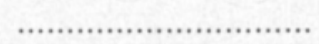 & 73-08-31 . .09-25 & $(342.0)$ & $(0.0850)$ & \\
\hline
\end{tabular}

The daily dry-matter yield $\mathrm{W}_{\mathrm{i}}$ of the sward was calculated from the height measurement observations. The corresponding amount of DVS was determined from equation 3.1. Logistic curves (Eq. 4.13) (Fig. 21) which passed through the origin were fitted to the observation pairs $W_{i}, s_{i}$. The primary growth for 1973 was estimated to be at the stubble height $(5 \mathrm{~cm})$ on 10.6 . The parameters of the logistic curves for different measurement series are presented in Table 2 .

The curves of the proper growth rate for the 1973 measurement series (Fig. 22) were then computed (Eq. 4.15) from the equation of the logistic curve. The special values of the proper growth rate and the theoretical maximum dry-matter yields for the 1973 measurement series are presented in Table 3 .

The dry-matter yield calculated from the daily height measurements and the corresponding DVS value of the sward could be easily fitted to the logistic 


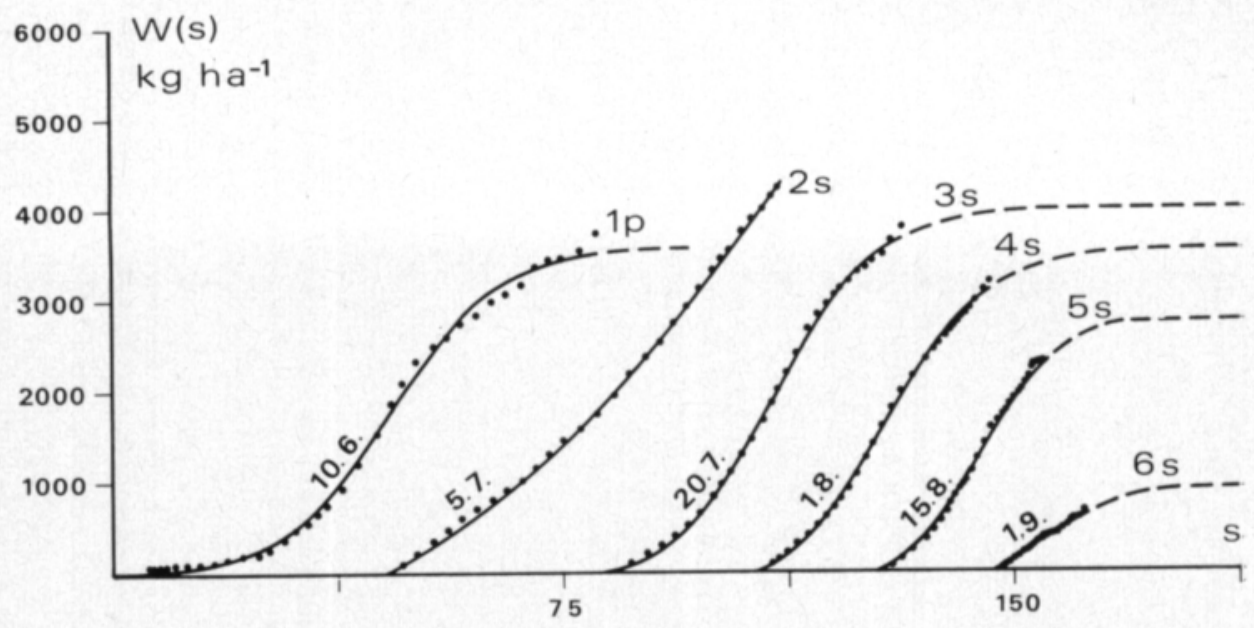

Fig. 21. The dependance between the amount of DVS and the dry-matter yield of Italian ryegrass in the 1973 measurement series. $\mathrm{p}=$ primary growth, $\mathrm{s}=$ secondary growth. The dots. are observed values. The dates above curves are initial instants of each series.

Table 2. The parameters of the equation (Eq. 4.13) for the relationship between the amount of DVS and the dry-matter yield of Italian ryegrass in the 1973 measurement series. $\mathrm{p}=$ primary growth, $\mathbf{s}=$ secondary growth.

\begin{tabular}{ccccc}
\hline Cutting series & $\mathrm{P}$ & $\mathrm{Q}$ & $\mathrm{C}$ \\
\hline $1 \mathrm{p}$ & $\ldots \ldots \ldots \ldots \ldots \ldots$ & 0.0002789 & 0.057800 & 0.11380 \\
$2 \mathrm{~s}$ & $\ldots \ldots \ldots \ldots \ldots \ldots$ & 0.0000421 & 0.000450 & 0.02092 \\
$3 \mathrm{~s}$ & $\ldots \ldots \ldots \ldots \ldots \ldots$ & 0.0002392 & 0.005310 & 0.11540 \\
$4 \mathrm{~s}$ & $\ldots \ldots \ldots \ldots \ldots \ldots$ & 0.0002581 & 0.002689 & 0.11540 \\
$5 \mathrm{~s}$ & $\ldots \ldots \ldots \ldots \ldots \ldots$ & 0.0003414 & 0.004936 & 0.16600 \\
$6 \mathrm{~s}$ & $\ldots \ldots \ldots \ldots \ldots \ldots$ & 0.0008610 & 0.003081 & 0.15730 \\
\hline
\end{tabular}

curve passing through the origin. However, some biased yield values were obtained at the end of the measurement series. For instance, the maximum dry-matter yield of the primary growth turned out to be about $3500 \mathrm{~kg} \cdot \mathrm{ha}^{-1}$, although earlier experiments indicated that it should increase to between $6000-7000 \mathrm{~kg} \cdot \mathrm{ha}^{-1}$. This error is caused by the fact that the height was always measured to the tip of the tallest blade. However, because of tillering the drymatter yield of the sward continued to increase after the height growth of the tallest blades had already ceased. In addition, the plants which were measured suffered some damage while the measurements were being carried out and they ceased height growth earlier than other plants in the sward. In order to obtain more accurate information about the dry-matter yield of the sward in the final stages of development, it was decided that the height measurements should be omitted in further studies because of the earlier mentioned error sources. A measurement method for the dry-matter yield which requires only yield samples was used in the 1974 field experiments. 


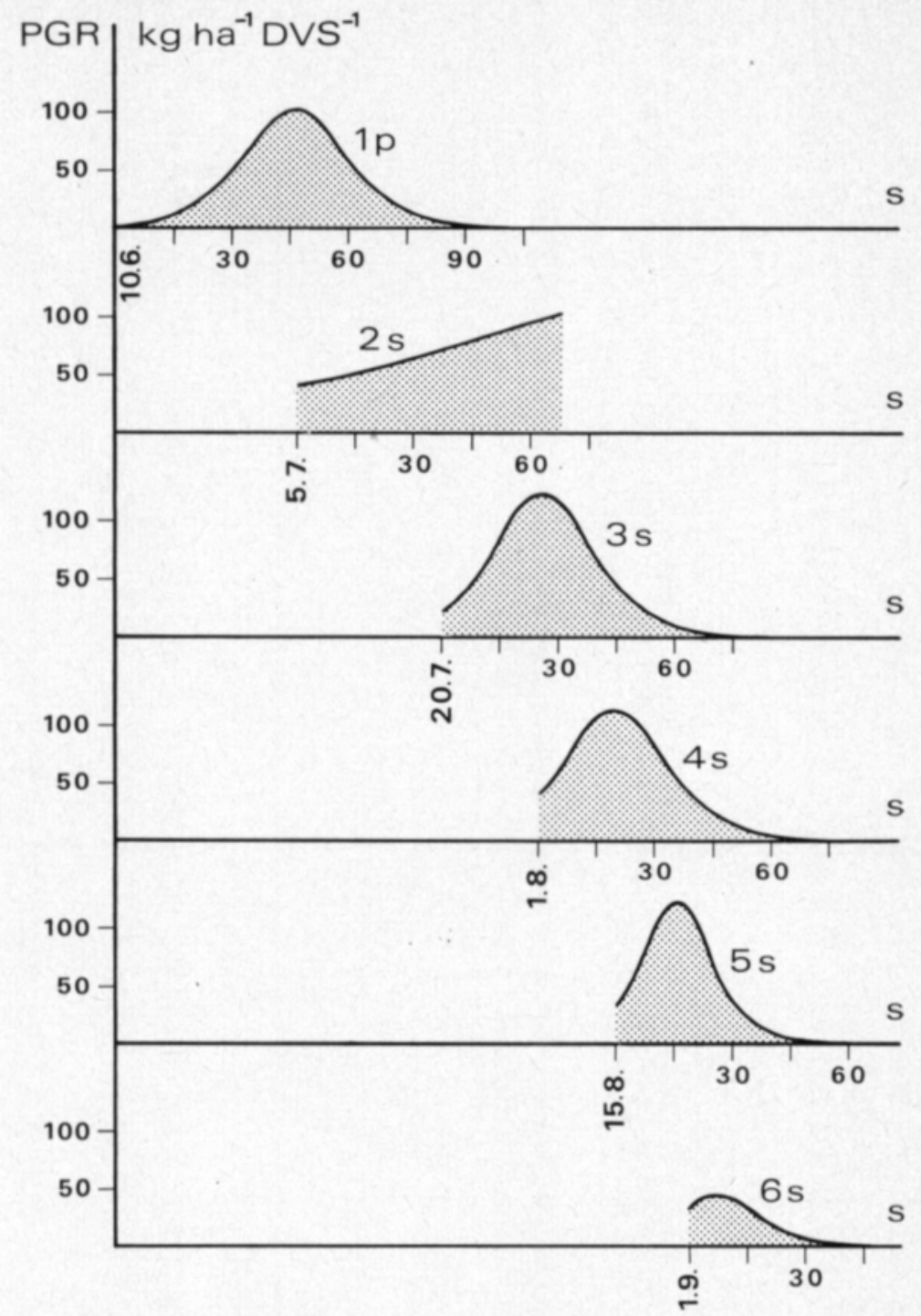

Fig. 22. Proper growth rate (PGR) in the 1973 measurement series. $\mathrm{p}=$ primary growth, $\mathrm{s}=$ secondary growth.

Table 3. Starting value $\alpha$ (Eq. 4.16) of the proper growth rate, the maximum value $\Omega$ (Eq. 4.17), the corresponding DVS value $s_{m}$ (Eq. 4.18) and the theoretical maximum dry-matter yield $\mathrm{W}_{\mathrm{m}}\left(\mathrm{Q} \cdot \mathrm{P}^{-1} \cdot(\mathrm{P}+\mathrm{Q})^{-1}\right)$, in the 1973 measurement series.

\begin{tabular}{|c|c|c|c|c|c|}
\hline Cutting & g series & $\mathrm{kg} \cdot \stackrel{a}{a} \mathrm{~h}^{-1}$ & $\begin{array}{c}\Omega \\
\text { DVS }^{-1}\end{array}$ & $\begin{array}{c}s_{\mathrm{m}} \\
\text { units of DVS }\end{array}$ & $\frac{\mathrm{W}_{\mathrm{m}}}{\mathrm{kg} \cdot \mathrm{ha}^{-1}}$ \\
\hline $1 \mathrm{p}$ & …................... & 1.95 & 102.01 & 46.87 & 3568 \\
\hline $2 s$ & ………............ & 38.91 & 124.38 & 113.87 & 21747 \\
\hline $3 \mathrm{~s}$ & n.............. & 20.14 & 122.07 & 26.54 & 4000 \\
\hline $4 \mathrm{~s}$ & (n...................... & 35.73 & 111.78 & 20.31 & 3535 \\
\hline $5 s$. & 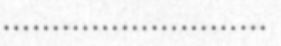 & 29.42 & 121.56 & 16.09 & 2740 \\
\hline $6 s$ & (n...................... & 31.20 & 45.72 & 8.11 & 909 \\
\hline
\end{tabular}




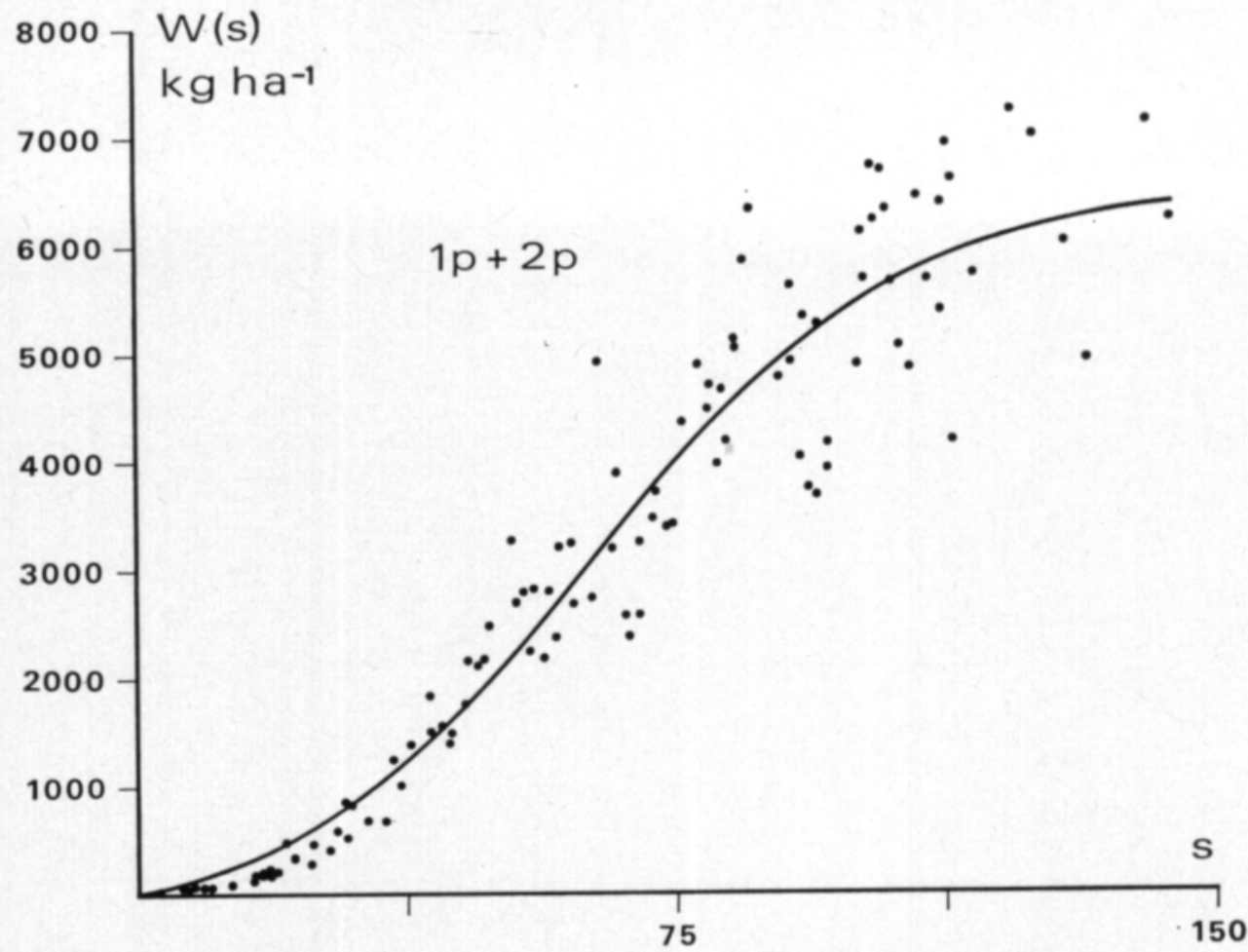

Fig. 23. The dependance between the amount of DVS and the dry-matter yield in the drymatter yield in the primary growth of Italian ryegrass in the 1974 measurement series. The dots are observed values.

\subsubsection{Results 1974}

Logistic curves (Figs. 23 and 24) passing through the origin were fitted to he 1974 primary observations (dry-matter yield samples $W_{i}$ and the correponding DVS values $s_{\mathrm{i}}$ ).

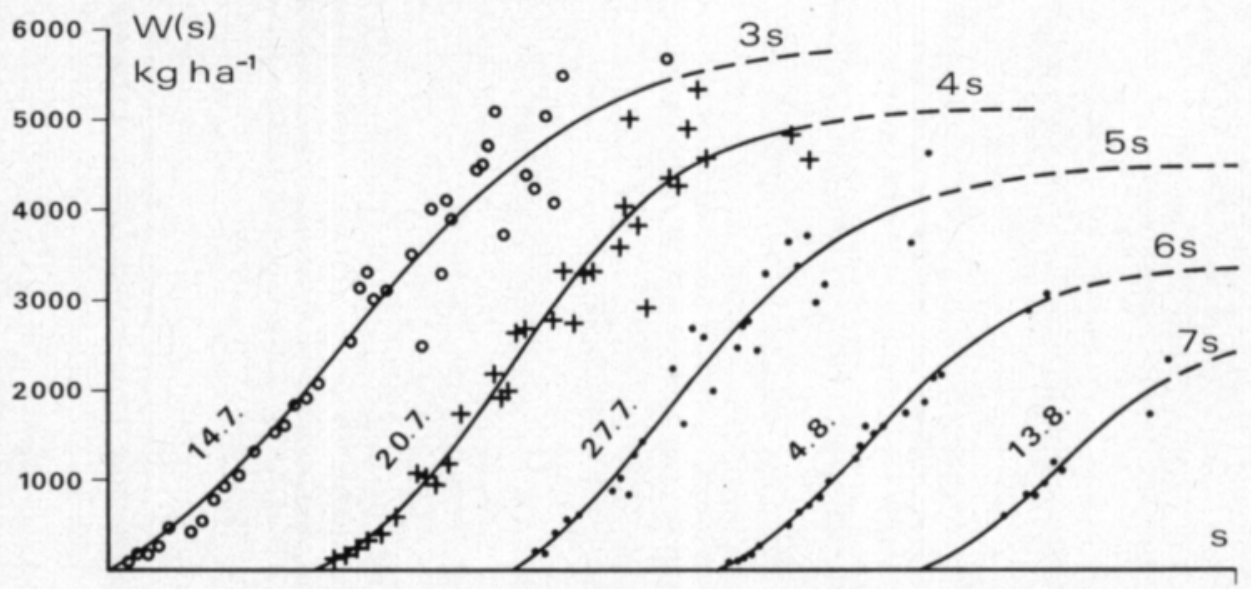

Fig. 24. The dependance between the amount of DVS and the dry-matter yield in the secondary growth of Italian ryegrass in the 1974 measurements series. The initial point in each series is not in the correct place on the $\mathrm{s}-$ axis. 


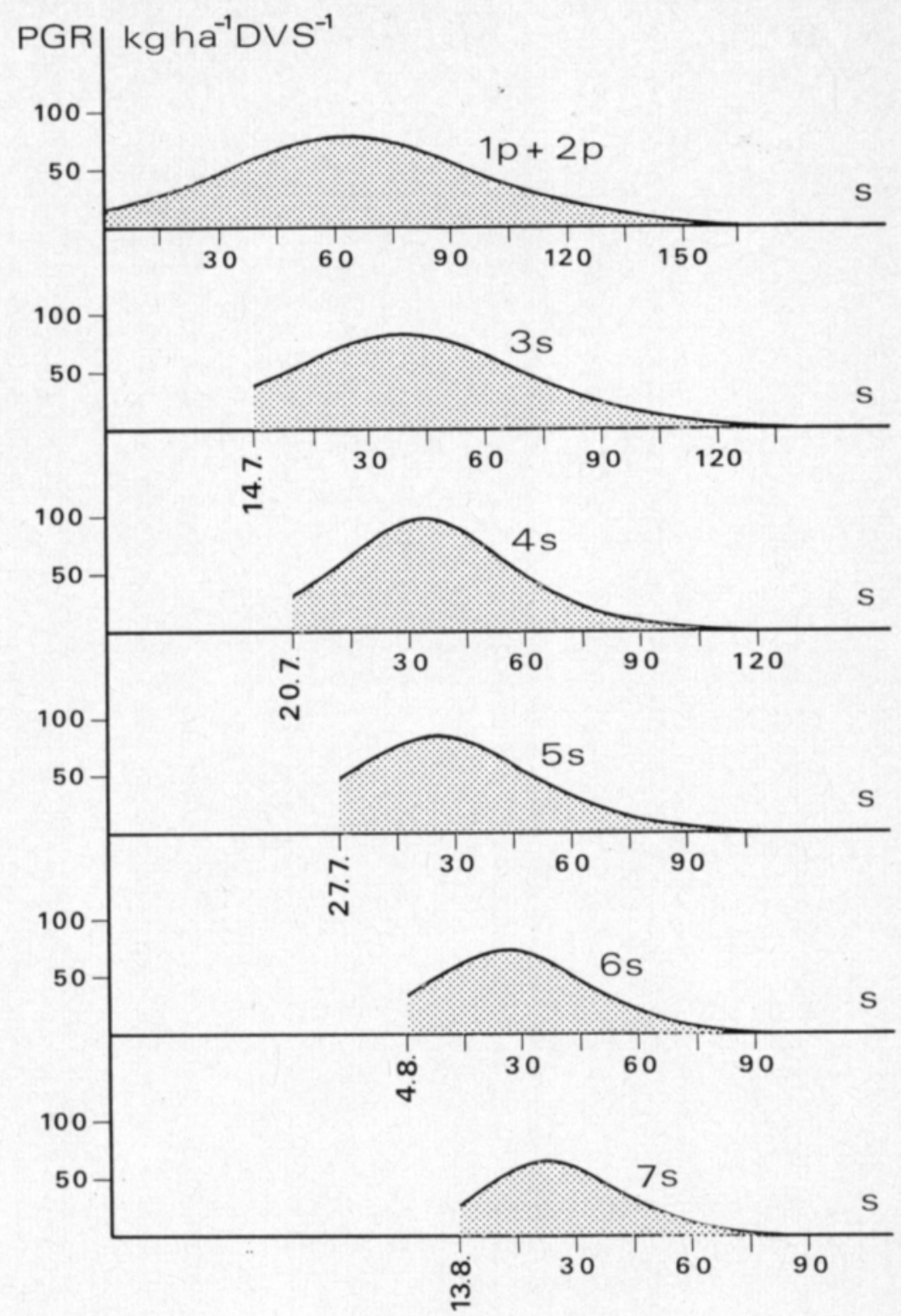

Fig. 25. The proper growth rate (PGR) in the 1974 measurement series. $\mathrm{p}=$ primary growth, $\mathrm{s}=$ secondary growth.

There were two primary growths. It was estimated that the first (sown on 15.5) reached the stubble height on 18.6 and the second (sown on 7.6) on 21.6. Before curve fitting, the observations from both of the primary growths were combined. The parameters of the logistic curve from different measurement series are presented in Table 4.

The graphs of the proper growth rate for the 1974 measurement series (Fig. 25) were then computed (Eq. 4.15) from the equation of the logistic curve. 
Table 4. The parameters of the equation (Eq. 4.13) for the relationship between the amount of DVS and the dry-matter yield of Italian ryegrass in the 1974 measurement series. $\mathrm{p}=$ primary growth, $\mathrm{s}=$ secondary growth.

\begin{tabular}{|c|c|c|c|c|c|}
\hline \multicolumn{2}{|c|}{ Cutting series } & period & $\mathrm{P}$ & $Q$ & C \\
\hline $1 p+2 p$ & $\ldots$ & $06-19 \ldots 09-14$ & 0.0001446 & 0.002668 & 0.04587 \\
\hline $3 \mathrm{~s}$ & .......... & $07-16 \ldots 09-14$ & 0.0001485 & 0.001016 & 0.04893 \\
\hline $4 \mathrm{~s}$ & . & $07-22 \ldots 09-14$ & 0.0001790 & 0.001928 & 0.06967 \\
\hline $5 \mathrm{~s}$ & ..................... & $07-29 \ldots 09-14$ & 0.0001833 & 0.000866 & 0.06102 \\
\hline $6 s$ & ....................... & $08-05 \ldots 09-14$ & 0.0002558 & 0.001707 & 0.07408 \\
\hline $7 \mathrm{~s}$ & & $08-16 \ldots 09-14$ & 0.0003308 & 0.002357 & 0.08481 \\
\hline
\end{tabular}

The special values of the proper growth rate of the 1974 measurement series and the theoretical maximum dry-matter yields are presented in Table 5.

Table 5. Starting value $\alpha$ (Eq. 4.16) of the proper growth rate, the maximum value $\Omega$ (Eq. 4.17), the corresponding DVS value $\mathrm{s}_{\mathrm{m}}$ (Eq. 4.18) and the theoretical maximum dry-matter yield $\mathrm{W}_{\mathrm{m}}\left(\mathrm{Q} \cdot \mathrm{P}^{-1} \cdot(\mathrm{P}+\mathrm{Q})^{-1}\right)$, in the 1974 measurement series.

\begin{tabular}{|c|c|c|c|c|}
\hline Cutting series & $\begin{array}{c}a \\
\mathrm{~kg} \cdot \mathrm{ha}^{-1}\end{array}$ & $\frac{\Omega}{(\mathrm{VS})^{-1}}$ & $\begin{array}{c}\mathrm{s}_{\mathrm{m}} \\
\text { units of DVS }\end{array}$ & $\begin{array}{c}\mathbf{W}_{\mathrm{m}} \\
\mathrm{kg} \mathrm{ha}^{-1}\end{array}$ \\
\hline $1 p+2 p \ldots \ldots \ldots \ldots \ldots \ldots \ldots$ & 15.47 & 79.31 & 63.55 & 6560 \\
\hline 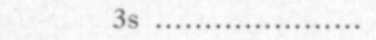 & 35.66 & 82.37 & 39.30 & 5875 \\
\hline 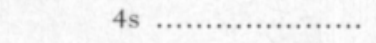 & 30.26 & 97.30 & 34.12 & 5112 \\
\hline 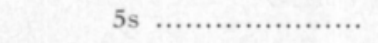 & 47.98 & 83.22 & 25.45 & 4503 \\
\hline 6s ........................ & 32.82 & 72.40 & 25.62 & 3400 \\
\hline 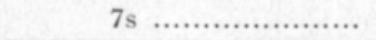 & 27.67 & 64.09 & 23.15 & 2651 \\
\hline
\end{tabular}

\subsubsection{Discussion}

Following the dry-matter yield of the sward by a combination of height measurements and yield determinations is an accurate method for it is based on continuous measurements carried out on the same plants (cf. ONDOK 1971). An apparently high degree of accuracy was reached in the 1973 measurement series because the observed values and the corresponding calculated values (Fig. 21) were close to each other. The accuracy is only apparent because, as was earlier mentioned, height growth ceases early and makes the yields obtained in the final stage of development unreliable.

The so-called destructive harvesting method (KvET et al. 1971), was used for determing the dry-matter yield in 1974. In this method, the same point in the sward cannot be used again for measurements. The heterogeneity of the sward and the substrate cause some variations in the yield samples and even negative growth is therefore sometimes observed between consecutive days. The variation in the yield determinations carried out in 1974 was large (Figs. 23 and 24). It further increased in the primary growth as a result of vole and reindeer damage at the end of the growing season. The measurement method is 
thus not as accurate as the one used in 1973, but it does however give some information about the yield during the final stages of development. The best measurement method would obviously be a combination of the two.

The logistic curve passing through the origin was well suited for describing the dependance between the amount of DVS and dry-matter yield in other cases apart from the 1974 primary growth. In the graph, the calculated values were situated above the observed values in the initial stages of development. This is due to the fact that the logistic curve determined by equation 4.11 is symmetrical as regards its point of inflection. Assymetry can be seen in the primary growth of 1974: the accelerating stage is steeper than the decelerating stage (Fig. 23). It would be possible to study the fitness of assymetrical logistical curves (cf. Steward 1968, p. 421, Fletcher 1974) in these cases. However, owing to the increasing number of parameters and the large variation in the material they were not used. Despite the obvious disadvantages of the symmetrical logistic curve concerning the initial stages of primary growth it can be used in the optimization presented later on because the biased points occur at such an early stage in the primary growth that cutting at that stage is not likely to occur.

There were two exceptions in the 1973 aftermath series: the first series $(2 s / 73)$ and the last $(6 s / 73)$. This can be clearly seen in the figure which shows the proper growth rate (Fig. 22). The first aftermath intially grew too slowly, there is no typical accelerating phase in the proper growth rate nor a maximum level reached during the measurement series. This was obviously affected by the dry period at the beninning July 1973. The last aftermath also grew too slowly in comparison with the others. The exceptionally cold conditions during September are the explanation for this. The sward remained frozen for a long time in the mornings following night frost, but the amount of DVS calculated from the temperature recorded in the weather chamber however increased. The measurements made in 1973 show that DVS cannot be calculated merely from the temperature recorded in the chamber if the sward as a result of drought or night frost is in an abnormal condition.

When examining the calculated graphs of the proper growth rate (Figs. 22 and 25), it is possible to discern certain regularities. The proper growth rate for the primary growth has a small starting value $(\alpha)$. It starts to increase in the aftermath and reaches a maximum value of approx. $45 \mathrm{~kg} \cdot \mathrm{ha}^{-1}$. (DVS units $)^{-1}$ in that sward in which the preceeding cutting has taken place at the end of July. It subsequently becomes smaller as autumn approaches. In point of fact no distinction can be made between the primary growth and the aftermath. There is only a certain growth potential which is determined by the degree of tillering of the sward and the size of the root system at that instant when the sward reaches a height of $5 \mathrm{~cm}$. This potential is described by the starting value $\alpha$ of the proper growth rate. Its value increases as the tillering of the sward and the size of the root system increases. By the end of the summer the magnitude of $\alpha$ again starts to decrease. The growth potential can be reduced for instance by a weakening in the activity of the roots or by the onset of wintering. The culmination point of the growth potential occurred in the experimental swards at the end of July. Thus the Italian ryegrass sward which 
was not cut before this date was able to produce an aftermath as efficiently as possible.

The effect of consolidation of the root system and tillering was also evident in how quickly the proper growth rate reached its maximum level. The closer it was to the initial instant of DVS, the further the growing season had progressed. Thus the faster the aftermath was able to achieve maximum net photosynthesis, the longer the sward had had time to consolidate before the cutting preceding the aftermath.

The maximum value $\Omega$ of the proper growth rate remained fairly constant during the measurement series carried out in early and middle summer, at $100-120 \mathrm{~kg} \cdot \mathrm{ha}^{-1}$. (DVS units) ${ }^{-1}$. The theoretical maximum crop growth rate (CGR) of Italian ryegrass at the Arctic Circle Experimental Station can be calculated from this value. The growth rate is thus high when both the development rate of the sward and the proper growth rate are simultaneously at as high a level as possible (CGR $=\mathrm{PGR} \cdot \mathrm{M})$. Thus if the weather conditions are favourable $(\mathrm{M} \approx 3)$ and the sward is at an appropriate stage of development $(\mathrm{PGR}=\Omega=100)$, then the daily yield increment will be $300 \mathrm{~kg} \cdot \mathrm{ha}^{-1} \cdot \mathrm{day}^{-1}$. A crop growth rate of similar magnitude has been measured for example in leys growing in England (cf. SPEDDING 1971, p. 24).

\subsection{Logistic growth curve and dynamic model of the crop growth rate}

The proper growth rate incorporated in a dynamic model of the crop growth rate of Italian ryegrass was determined from field observations made in 1973 and 1974 as a derivative of the logistic growth curve. For the sake of abbreviation let the vector $\mathrm{V}$ denote the parameters of the logistic curve: $\mathrm{V}=(\mathrm{P}$, $\mathrm{Q}, \mathrm{C})$. Thus the proper growth rate depends on both the vector $\mathrm{V}$ and the amount (s) of DVS:

$$
P G R=f(V, s)
$$

Information about the magnitude of the proper growth rate in the different stages of development is included in the vector $\mathrm{V}$.

From this point onwards the study is limited to the treatment of the model of the crop growth rate using as an example the 1974 experimental sward at the Arctic Circle Experiment Station (cf. p.79). In order to be able to use the model of the crop growth rate for optimization it must first undergo rather extensive simplifications. Let us assume that the parameters for the proper growth rate (vector $\mathrm{V}$ ) remain constant throughout the growing period. The values of these parameters depend upon which instant in the growing season is chosen as the initial instant of DVS in each sward (Fig. 26). The parameters also include some information about all the growth factors (biotic and abiotic) apart from temperature.

The constancy of the parameters takes for granted the fact that the growth factors remain unchanged during the growth period. For example, the moisture conditions are assumed to be optimal throughout the course of the 

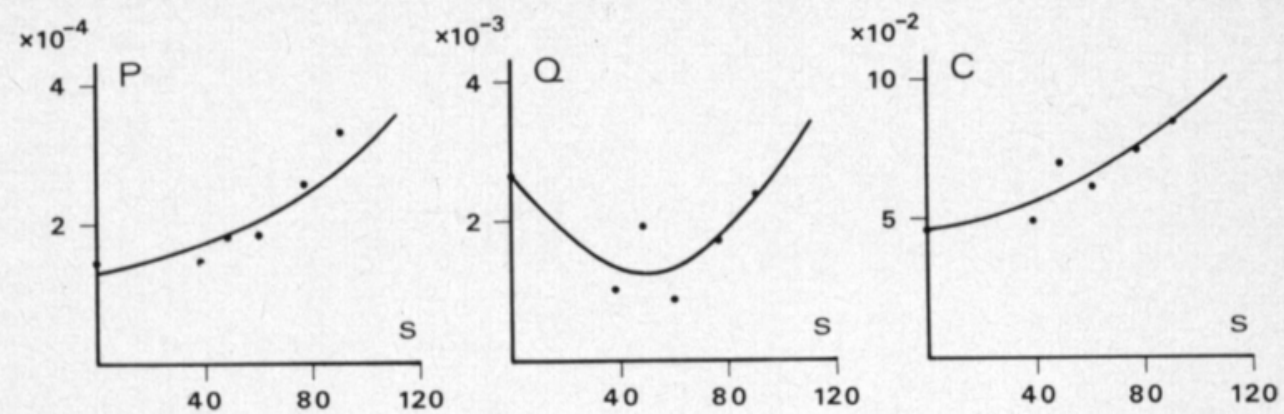

Fig. 26. Parameters $P, Q$ and $C$ (Eq. 4.15) in the experimental swards located at different points inside the growing season (1974). The dots are observed values taken from Table 4.

experiment, and nitrogen fertilizer is only added in conjunction with cuttings. The intensity of the incoming radiation is assumed to be sufficient to keep the quantity of primary products produced in photosynthesis (source) always greater than the amount synthesised from them in further metabolism (sink) (cf. Watson 1971, Evans 1975). Moreover, when parameters P, $Q$ and $C$ have been determined at the initial instant of DVS, the dry-matter yield is dependant only on the amount of DVS. The development rate affecting this is assumed to be dependant on the temperature (Fig. 9).

The following criterion was employed in the choice of the equation to be used for determining the proper growth rate of Italian ryegrass: how well do the calculated and observed values correspond to each other ("best fit"). The model of the crop growth rate is thus demonstrative (DE WIT 1970). It has no power of explanation and it can only be used to describe the growth occuring under certain conditions (STEWARD 1968, p. 431). However, the demonstrative model also has some use in optimization (cf. Jones 1970). 


\section{Optimum cutting schedule for Italian ryegrass}

By the optimum cutting schedule is meant the choosing of the cutting dates within the growing season such that the total yield calculated as the sum of the individual cuttings is maximised. As has earlier been mentioned, (p.78), maximization is based on the fact that the crop growth rate of the ley (daily growth) is kept at as high a level as possible. When a dynamic model of the crop growth rate of Italian ryegrass is connected to this principle, the optimum cutting schedule is that which maintains the value for the product of the proper growth rate and the development rate (see p.96) at as high a level as possible. In this study, the development rate is assumed to be dependant only on the temperature, which cannot be affected by any agricultural practices. It is thus sufficient if the cutting dates are chosen so that the proper growth rate only is kept at as high a level as possible. In other words, agricultural practices must be planned so that Italian ryegrass sward is kept, from the point of view of its growth potential, in as favourable a development stage as possible.

An optimum cutting schedule is to be found for a hypothetical Italian ryegrass sward which has been sown on such a day that the primary growth reaches the stubble height $(5 \mathrm{~cm})$ on 18.6. It is fertilized at this stage with $200 \mathrm{~N} \mathrm{~kg} \cdot \mathrm{ha}^{-1}$. A similar fertilizer dose is applied in conjunction with cutting. If the growing season ceases on 30.9 , when the last cutting is carried out, then there will be 105 days in this particular growing season. According to the 1974 temperature data there will be approx. 106 units of DVS in the growing season.

During a certain growing season, the optimum cutting schedule is, as far as the weather conditions are concerned, deterministic. This means that when the same input is used, the final result is always the same (ANDERSIN 1968). The necessary input data is as follows:

1) the length of the growing season (105 days)

2) the corresponding temperature data (temperature observations taken at hourly intervals during the period $1974-06-18 \ldots 09-30$ )

3) the values of parameters $\mathrm{P}, \mathrm{Q}$ and $\mathrm{C}$ (vector $\mathrm{V}$ ) of the proper growth rate of Italian ryegrass at the initial instant of DVS of the sward (Fig. 26). 


\subsection{Two cuttings}

The search for the optimum cutting schedule is started by considering a simple case: the sward is cut only twice. Since the final cutting date is fixed, i.e. 30.9 , only the date of the first cutting can be varied. In this case, the optimum cutting time is thus that moment in the middle of the growing season at which the sward must be cut if the total dry-matter yield calculated as the sum of the two cuttings is to be maximised.

The progression of the proper growth rate in a sward which has been cut twice is shown in Fig. 27.

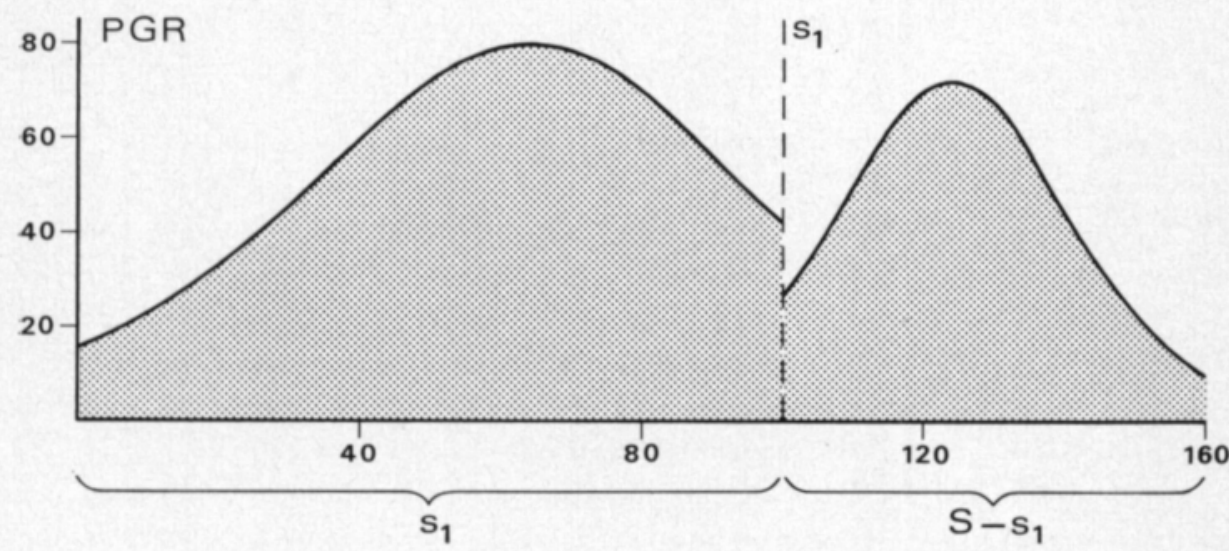

Fig. 27. The first cutting instant $\left(s_{1}\right)$ of a twice cut sward timed to the growing season. The length of the whole growing season is S. The time-axis is in DVS units.

The development stage has been deliberately used for the timeaxis since it makes the calculations more simple. The shaded area under the curve up to the instant $s_{1}$ represents the dry-matter yield $\left(W_{1}\right)$ obtained in the first cutting (cf. Eq. 4.4). The area under the curve from the instant $s_{1}$ to the end of the growing season represents the dry-matter yield $\left(\mathrm{W}_{2}\right)$ obtained in the second cutting. The total dry-matter yield $W_{t}$ (the entire shaded area) is maximised by determining the value of $s_{1}$ such that the proper growth rate (PGR) is maintained at as high level as possible.

The dry-matter yield obtained in the cutting is calculated from the integral function of the proper growth rate, which in this study is a logistic curve passing through the origin (Eq. 4.13.). The dry-matter yield of the cutting thus depends partly on the amount of DVS and partly on the vector V (cf. Eq. 4.20):

$$
\mathrm{W}=\mathrm{F}(\mathrm{V}, \mathrm{s})
$$

In the primary growth the vector is always the same, i.e. $\mathrm{V}_{\mathrm{o}}$. The length of the growing period is $s_{1}$. The dry-matter yield $W_{1}$ obtained in the first cutting is

$$
\mathrm{W}=\mathrm{F}\left(\mathrm{V}_{\mathrm{o}}, \mathrm{s}_{1}\right)
$$


In the aftermath the vector is governed by the date of the first cutting (Fig. 26), i.e. $\mathrm{V}=\mathrm{V}\left(\mathrm{s}_{1}\right)$. The length of the growing period is $\mathrm{S}-\mathrm{s}_{1}$. The drymatter yield $\mathrm{W}_{2}$ obtained in the second cutting is thus.

$$
\mathrm{W}_{2}=\mathrm{F}\left(\mathrm{V}\left(\mathrm{s}_{1}\right), \mathrm{S}-\mathrm{s}_{1}\right)
$$

The only independant variable in equations $\mathbf{5 . 2}$ and $\mathbf{5 . 3}$ is $\mathrm{s}_{\mathbf{1}}$. Thus the total dry-matter yield $\mathrm{W}_{\mathrm{t}}$ depends only on the instant of the first cutting:

$$
\mathrm{W}_{1}\left(\mathrm{~s}_{1}\right)=\mathrm{W}_{1}\left(\mathrm{~s}_{1}\right)+\mathrm{W}_{2}\left(\mathrm{~s}_{1}\right)
$$

The maximum value of the total dry-matter yield can be found for instance by studying the zero point of the derivative:

$$
\mathrm{dW}_{\mathrm{t}} / \mathrm{ds}_{1}=0
$$

Equation 5.5 was solved numerically by computing the value of the derivative when $s_{1}$ was varied by an interval of one unit (Table 6). The total dry-matter yield reached a maximum value of $8199 \mathrm{~kg} \cdot \mathrm{ha}^{-1}$ when the first cutting was carried out approximately 100 units of DVS after the start of the growing season. The corresponding chronological time instant was calculated using equation 3.1 and rounded off to the morning following the DVS instant. Thus $\mathbf{5 5}$ days of chronological time had passed before the first cutting was carried out. The date corresponding to this is 1974-08-12.

Besides the determination of the optimum cutting schedule using this computational technique, sensitivity analysis is also obtained: to what extent does the dry-matter yield change when the date of the first cutting is moved for-

Table 6. The effect of the instant of the first cutting $\left(\mathrm{s}_{1}\right.$, in units of DVS) on the total drymatter yield $\left(W_{t}\right)$ of Italian ryegrass cut twice. $W_{1}=$ yield from first cutting, $W_{2}=$ yield from second cutting $\left(\mathrm{kg} \cdot \mathrm{ha}^{-1}\right)$.

\begin{tabular}{rrrrrr}
\hline $\mathrm{s}_{\mathbf{1}}$ & $\mathrm{W}_{\mathbf{1}}$ & $\mathrm{W}_{2}$ & $\mathrm{~W}_{\mathrm{t}}$ & derivative & date \\
\hline 90 & 4957 & 3150 & 8107 & 17.6 & $-08-05$ \\
91 & 5013 & 3111 & 8124 & 15.9 & $-08-05$ \\
92 & 5067 & 3072 & 8139 & 14.2 & $-08-06$ \\
93 & 5120 & 3032 & 8153 & 12.8 & $-08-07$ \\
94 & 5172 & 2993 & 8164 & 10.8 & $-08-07$ \\
95 & 5222 & 2952 & 8174 & 9.1 & $-08-08$ \\
96 & 5271 & 2912 & 8183 & 7.4 & $-08-09$ \\
97 & 5318 & 2871 & 8189 & 5.7 & $-08-10$ \\
98 & 5364 & 2830 & 8194 & 4.0 & $-08-10$ \\
99 & 5409 & 2788 & 8197 & 2.3 & $-08-11$ \\
100 & 5452 & 2747 & 8199 & 0.6 & $-08-12$ \\
101 & 5494 & 2704 & 8199 & -1.1 & $-08-12$ \\
102 & 5535 & 2662 & 8197 & -2.8 & $-08-13$ \\
103 & 5574 & 2619 & 8193 & -4.5 & $-08-13$ \\
104 & 5613 & 2576 & 8188 & -6.1 & $-08-14$ \\
105 & 5649 & 2532 & 8181 & -7.8 & $-08-15$ \\
\hline
\end{tabular}




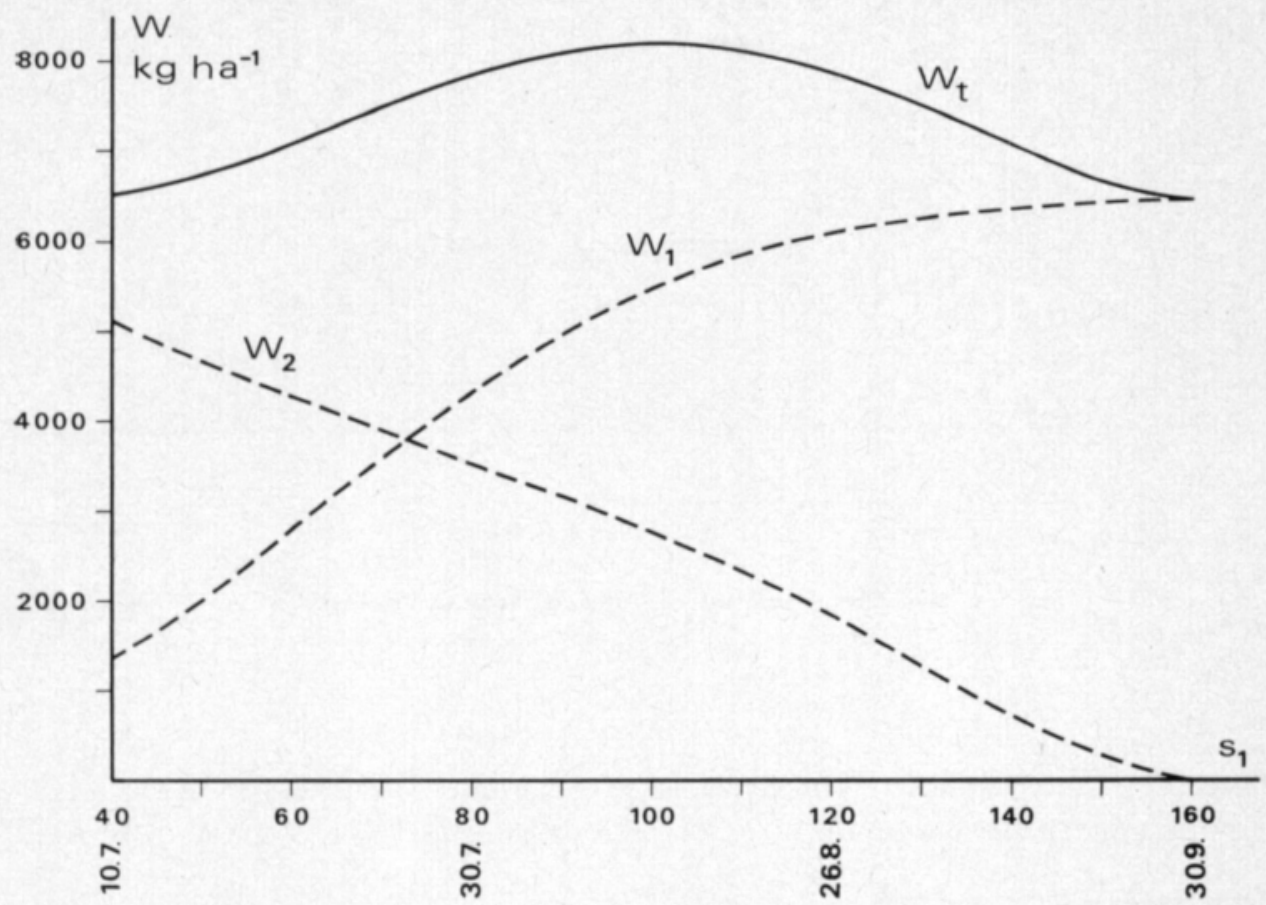

Fig. 28. Effect of the instant of the first cutting ( $s_{1}$ units of DVS) on the total dry-matter yield of Italian ryegrass cut twice. $W_{1}=$ first cutting, $W_{2}=$ second cutting, $W_{1}=$ total.

wards or backwards, for instance by one week, from the optimum date (Fig. 28 ). The total dry-matter yield is not very sensitive to change in the cutting schedule. For instance, when the date of the first cutting is moved forwards by almost a month (to 1974-09-07), the total dry-matter yield is reduced by only $1000 \mathrm{~kg} \cdot \mathrm{ha}^{-1}$.

\subsection{Three cuttings}

When the sward is cut three times, the date of the final cutting is again fixed (1974-09-30), but in this case the two previous cutting dates can be varied. In this case the optimum cutting schedule is the selection of those dates in the middle of the growing season which maximise the total dry-matter yield calculated as the sum of the three individual cuttings.

Let us denote the second cutting instant by $\mathrm{s}_{2}$ and the yield obtained from the third cutting by $\mathrm{W}_{3}$, the other symbols are the same as those used earlier. The shaded area under the curve in Fig. 29 again represents the dry-matter yields obtained from the different cuttings. The cutting instants $s_{1}$ and $s_{2}$ are to be selected in the growing season such that that the proper growth rate is maintained at as high level as possible.

The dry-matter yield of the primary growth, $\mathrm{W}_{1}$, is the same as that used earlier (Eq. 5.2.). In the secondary growth the parameters are governed by the 


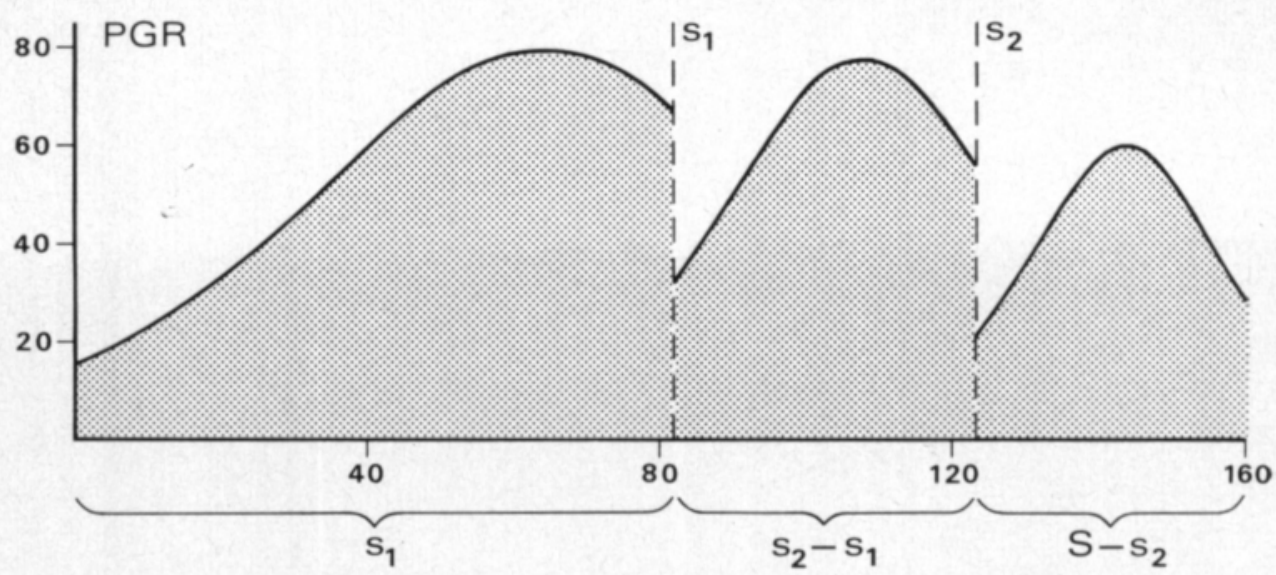

Fig. 29. The first $\left(s_{1}\right)$ and the second $\left(s_{2}\right)$ cutting instants of a sward cut three times timed to the growing season. The length of the whole growing season is S. The time-axis is in DVS units.

instant of the first cutting in the same way as earlier (see p. 114), but the length of the growth period is now $s_{2}-s_{1}$. The dry-matter yield $\mathrm{W}_{2}$ obtained in the second cutting is

$$
\mathrm{W}_{2}=\mathrm{F}\left(\mathrm{V}\left(\mathrm{s}_{1}\right), \mathrm{s}_{2}-\mathrm{s}_{1}\right)
$$

In the tertiary growth the vector is governed by the instant of the second cutting, i.e. $\mathrm{V}=\mathrm{V}\left(\mathrm{s}_{2}\right)$. The length of the growing period is $\mathrm{S}-\mathrm{s}_{2}$. The drymatter yield $\mathrm{W}_{3}$ obtained in the third cutting is

$$
\mathrm{W}_{3}=\mathrm{F}\left(\mathrm{V}\left(\mathrm{s}_{2}\right), \mathrm{S}-\mathrm{s}_{2}\right)
$$

The independant variables in the case of the first yield are $s_{1}$, in the second $s_{1}$ and $s_{2}$, and in the third $s_{2}$. The total dry-matter yield $W_{t}$ is thus a function of two variables, the instants of the first and second cutting.

$$
\mathrm{W}_{\mathrm{t}}\left(\mathrm{s}_{1}, \mathrm{~s}_{2}\right)=\mathrm{W}_{1}\left(\mathrm{~s}_{1}\right)+\mathrm{W}_{2}\left(\mathrm{~s}_{1}, \mathrm{~s}_{2}\right)+\mathrm{W}_{3}\left(\mathrm{~s}_{2}\right)
$$

The maximum value of the dry-matter yield is found by studying the zero points of both of the partial derivatives (cf. Eq. 5.5):

$$
\partial \mathrm{W}_{\mathrm{t}} / \partial \mathrm{s}_{1}=0 \text { and } \partial \mathrm{W}_{\mathrm{t}} / \partial \mathrm{s}_{2}=0
$$

In principle, equation 5.9 can be solved numerically by using the same technique as for equation 5.5. If the cutting instants are varied for example by one (chronological) day, then the total number of possible combinations is 5356. However, it is not necessary to calculate all of these if some mathematical programming method is used, for example dynamic programming (cf. Hillier and Lieberman 1969, p. 239, Sirtonen 1972). The so-called gradient method (cf. Manninen and Salmi 1974) can be used in this study since the partial derivatives of equation 5.9 can be calculated, numerically at least, with any value of $s_{1}$ and $s_{2}$. The gradient method is illustrated in the following figure (Fig. 30): 


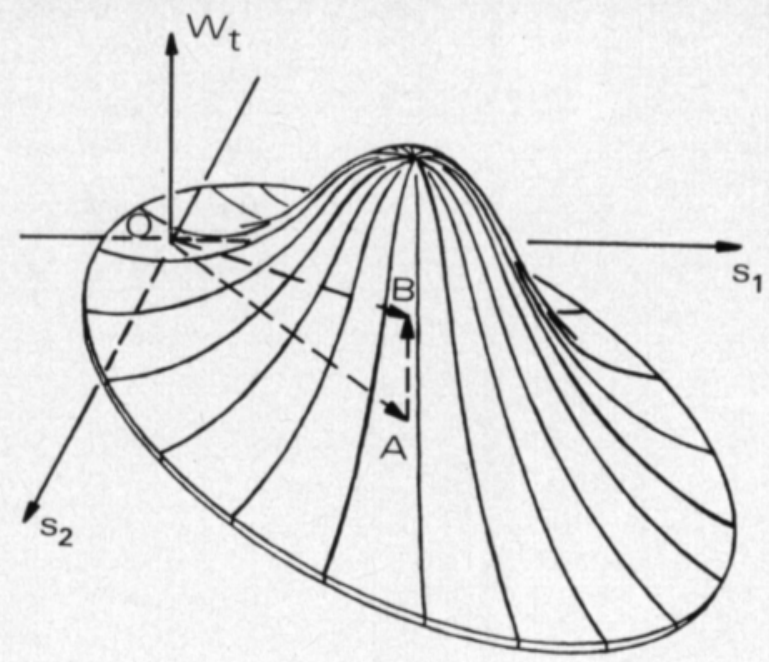

Fig. 30. The effect of the first $\left(s_{1}\right)$ and the second $\left(s_{2}\right)$ cutting instant on the total dry-matter yield of Italian ryegrass cut three times (model). A = estimated cutting schedule, $\mathrm{B}=$ improved cutting schedule.

Let us take as the starting point some random cutting schedule (point A in the figure), for example at the DVS instants 55 (1974-07-18) and 108 (197408-17). Since the randomly selected cutting schedule is obviously not the optimum one, it must be changed. Let us then change both the cutting instants so that the total dry-matter yield (the height of the point in Fig. 30) increases as fast as possible, i.e. it is moved in the direction of the gradient (cf. e.g. SPIEgel 1959, p. 62). Let point $\mathrm{B}$ be in such a direction. The new cutting schedule is obtained by changing the old cutting schedule as follows (see Appen$\operatorname{dix} 2)$ :

$$
\begin{aligned}
& \mathrm{S}_{1}(\mathrm{~B})=\mathrm{S}_{1}(\mathrm{~A})+\frac{\frac{\partial \mathrm{W}_{\mathrm{t}}}{\partial \mathrm{s}_{1}}}{\sqrt{\left(\frac{\partial \mathrm{W}_{\mathrm{t}}}{\partial \mathrm{s}_{1}}\right)^{2}+\left(\frac{\partial \mathrm{W}_{\mathrm{t}}}{\partial \mathrm{s}_{2}}\right)^{2}}} \\
& \mathrm{~S}_{2}(\mathrm{~B})=\mathrm{S}_{2}(\mathrm{~A})+\frac{\frac{\partial \mathrm{W}_{\mathrm{t}}}{\partial \mathrm{s}_{2}}}{\sqrt{\left(\frac{\partial \mathrm{W}_{\mathrm{t}}}{\partial \mathrm{s}_{1}}\right)^{2}+\left(\frac{\partial \mathrm{W}_{\mathrm{t}}}{\partial \mathrm{s}_{2}}\right)^{2}}}
\end{aligned}
$$

In order to maximise the total dry-matter yield at point $B$, the square root expression, the directional derivative in the direction of the gradient (sdr), found in equations 5.10 and 5.11 must be nought. However, if it is not, then a new cutting time point $\mathrm{C}$ must be found by moving from point $\mathrm{B}$ in the direction of the gradient.

The method can be programmed in a computer so that the direction of the gradient vector at point $\mathrm{A}$ is first calculated. Let us then move in this direction a certain distance (sdr multiplied by some constant). This process is re- 
Table 7. The effect of the instants of the first and second cuttings $\left(s_{1}\right.$ and $s_{2}$, in units of DVS) on the total dry-matter yield $\left(W_{t}\right)$ of Italian ryegrass cut three times. $W_{1}=$ yield from first cutting, $W_{2}=$ yield from the second cutting, $W_{3}=$ yield from the third cutting $\left(\mathrm{kg}^{\circ} \mathrm{ha}^{-1}\right)$ sdr $=$ directional derivative.

\begin{tabular}{lllllllll}
\hline $\mathrm{s}_{1}$ & $\mathrm{~s}_{2}$ & $\mathrm{~W}_{1}$ & $\mathrm{~W}_{2}$ & $\mathrm{~W}_{3}$ & $\mathrm{~W}_{\mathrm{t}}^{\prime}$ & $\mathrm{sdr}$ & \multicolumn{2}{c}{ dates } \\
\hline 55 & 108 & 2470 & 3458 & 2389 & 8318 & 18.1 & $-07-18$ & $-08-17$ \\
65 & 111 & 3217 & 3033 & 2247 & 8498 & 17.0 & $-07-23$ & $-08-19$ \\
73 & 116 & 3867 & 2791 & 1982 & 8640 & 10.5 & $-07-27$ & $-08-23$ \\
81 & 123 & 4419 & 2632 & 1649 & 8701 & 0.9 & $-07-31$ & $-08-28$ \\
88 & 130 & 4862 & 2545 & 1250 & 8656 & 10.2 & $-08-04$ & $-09-02$ \\
87 & 129 & 4829 & 2539 & 1297 & 8666 & 9.0 & $-08-03$ & $-09-02$ \\
87 & 128 & 4792 & 2540 & 1342 & 8674 & 7.9 & $-08-03$ & $-09-01$ \\
86 & 128 & 4752 & 2545 & 1385 & 8681 & 6.8 & $-08-03$ & $-08-31$ \\
85 & 127 & 4709 & 2554 & 1425 & 8687 & 5.7 & $-08-02$ & $-08-31$ \\
85 & 126 & 4663 & 2565 & 1464 & 8692 & 4.6 & $-08-02$ & $-08-30$ \\
84 & 126 & 4617 & 2577 & 1502 & 8696 & 3.5 & $-08-02$ & $-08-30$ \\
83 & 125 & 4569 & 2591 & 1539 & 8699 & 2.4 & $-08-01$ & $-08-29$ \\
83 & 124 & 4520 & 2604 & 1576 & 8701 & 1.3 & $-08-01$ & $-08-29$ \\
82 & 124 & 4471 & 2619 & 1612 & 8701 & 0.3 & $-08-01$ & $-08-28$ \\
81 & 123 & 4420 & 2633 & 1648 & 8701 & 0.8 & $-07-31$ & $-08-28$ \\
81 & 123 & 4425 & 2631 & 1644 & 8701 & 0.7 & $-07-31$ & $-08-28$ \\
81 & 123 & 4430 & 2630 & 1640 & 8701 & 0.6 & $-07-31$ & $-08-28$ \\
81 & 123 & 4435 & 2629 & 1637 & 8701 & 0.5 & $-07-31$ & $-08-28$ \\
81 & 123 & 4440 & 2627 & 1633 & 8701 & 0.4 & $-07-31$ & $-08-28$ \\
81 & 123 & 4446 & 2626 & 1630 & 8701 & 0.3 & $-07-31$ & $-08-28$ \\
82 & 123 & 4451 & 2624 & 1626 & 8701 & 0.2 & $-07-31$ & $-08-28$ \\
82 & 123 & 4456 & 2623 & 1623 & 8701 & 0.1 & $-07-31$ & $-08-28$ \\
82 & 123 & 4461 & 2621 & 1619 & 8701 & 0.0 & $-07-31$ & $-08-28$ \\
\hline
\end{tabular}

peated so many times that the total dry-matter yield starts at some point to decrease (the "peak" in Fig. 30 has been traversed). The length of the step is now decreased to a tenth of that used earlier, and the traversing is repeated until sdr comes close enough to nought (the accuracy required can be chosen in advance).

The optimum cutting schedule of Italian ryegrass cut three times which was obtained by the gradient method is presented in Table 7. The total dry matter yield approaches its maximum value if the first cutting is carried out after 82 units of DVS and the second after 123 units of DVS. This corresponds to 43 and 71 days of chronological time respectively. The dates of the optimum cutting schedule are 1974-07-29 and -08-28 (and -09-30). The yield of the randomly selected cutting schedule (-07-18 and -08-17) was $8318 \mathrm{~kg} \cdot \mathrm{ha}^{-1}$. The maximum yield $8701 \mathrm{~kg} \cdot \mathrm{ha}^{-1}$ was first found after 4 iteration cycles.

The sensitivity of the maximum dry-matter yield of Italian ryegrass cut three times to changes in the cutting schedule was tested by calculating combinations of different cutting instants one (chronological) day at a time (Fig. 31). One must imagine that the diagramme in Fig. 31 is projected onto the base level of a 3-dimensional drawing like the one in Fig. 30. The different cutting schedules and corresponding total dry-matter yields can be read from the 


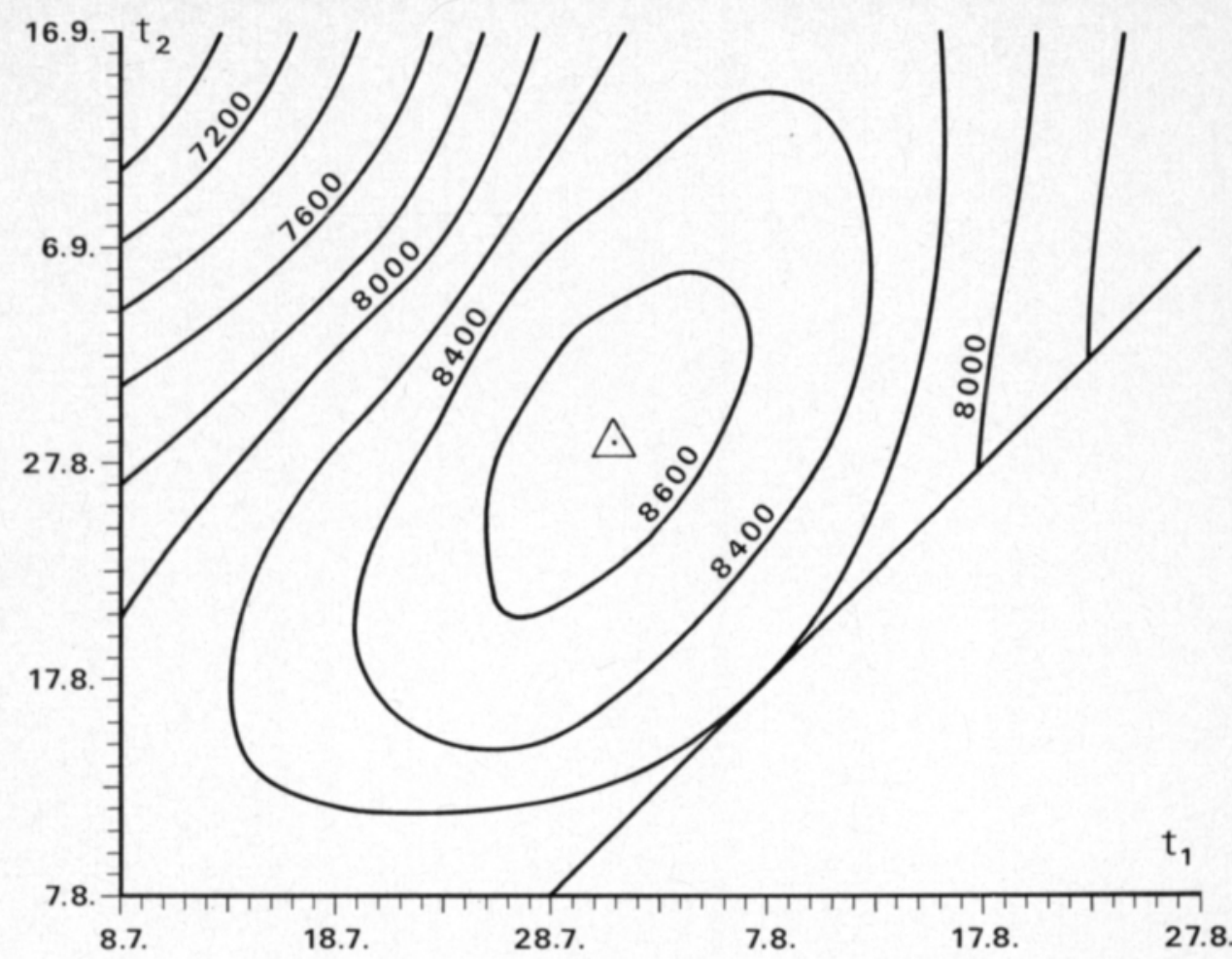

Fig. 31. Effect of the first and second cutting dates on the total dry-matter yield of Italian ryegrass cut three times. $t_{1}=$ first cutting date, $t_{2}=$ second cutting date. The yield contours in the figure have intervals of $200 \mathrm{~kg} \cdot \mathrm{ha}^{-1}$.

"height contours". The maximum dry-matter yield obtained when three cuttings are made is not especially sensitive to small changes in the cutting schedule. In order to reduce the total dry-matter yield by for instance $500 \mathrm{~kg} \cdot \mathrm{ha}^{-1}$, the first cutting may be delayed for about two weeks and the second for almost three weeks.

\subsection{Four or more cuttings}

Determination of the optimum cutting schedule by the gradient method can easily be generalized to the selection of a schedule involving four or more cuttings. When four cuttings are carried out, the first three cutting instants can be varied $\left(s_{1}, s_{2}\right.$ and $\left.s_{3}\right)$. The cutting schedule is the optimum one when the partial derivatives calculated with respect to all these instants vanish. Correspondingly, when five cuttings are carried out, the first four cuttings can be varied. The zero points of the partial derivatives are found by means of a similar gradient method as the one used earlier, starting from some randomly selected cutting schedule.

An attempt to find the optimum cutting schedule for an Italian ryegrass to be cut four times, is presented in Table 8 . It can be seen that the duration 
Table 8. The effect of the instants of the first, second and third cuttings $\left(s_{1}, s_{2}\right.$ and $s_{3}$, in units of DVS) on the total dry-matter yield $\left(\mathrm{W}_{\mathrm{t}}\right)$ of Italian ryegrass cut four times. $\mathrm{W}_{1}=$ yield from first cutting, $\mathrm{W}_{2}=$ yield from second cutting, $\mathrm{W}_{3}=$ yield from third cutting, $\mathrm{W}_{4}=$ yield from fourth cutting $\left(\mathrm{kg} \cdot \mathrm{ha}^{-1}\right)$.

\begin{tabular}{rrrrrrrr}
\hline $\mathrm{s}_{1}$ & $\mathrm{~s}_{2}$ & $\mathrm{~s}_{\mathbf{3}}$ & $\mathrm{W}_{\mathbf{1}}$ & $\mathrm{W}_{\mathbf{2}}$ & $\mathrm{W}_{\mathbf{3}}$ & $\mathrm{W}_{\mathbf{4}}$ & $\mathrm{Wt}$ \\
\hline 57 & 100 & 127 & 2606 & 2865 & 1459 & 1448 & 8379 \\
59 & 98 & 130 & 2768 & 2551 & 1904 & 1227 & 8450 \\
63 & 99 & 133 & 3039 & 2418 & 1951 & 1066 & 8473 \\
66 & 102 & 135 & 3306 & 2380 & 1864 & 941 & 8490 \\
69 & 105 & 138 & 3530 & 2389 & 1795 & 788 & 8502 \\
71 & 108 & 141 & 3706 & 2430 & 1765 & 610 & 8511 \\
73 & 111 & 145 & 3840 & 2486 & 1777 & 420 & 8523 \\
74 & 114 & 149 & 3945 & 2545 & 1809 & 248 & 8547 \\
76 & 116 & 153 & 4034 & 2600 & 1840 & 114 & 8589 \\
77 & 118 & 158 & 4118 & 2648 & 1857 & 26 & 8648 \\
77 & 119 & 160 & 4151 & 2665 & 1858 & 2 & 8676 \\
82 & 123 & 160 & 4461 & 2621 & 1619 & 0 & 8701 \\
\hline
\end{tabular}

of the last growing period approaches nought. This is an indication of the fact that the best result is obtained when the sward is cut only three times.

The cutting schedule obtained with the gradient method is not necessarily the optimal one, for the maximum which is found may be only relative (local maximum, the diagramme in Fig. 30 has more than one peak). The absolute maximum is generally found by choosing a number of starting points which differ completely from each other and starting from them. If the same solution is obtained every time, then the cutting schedule is obviously the optimum one, but in order to be absolutely sure, all the possible alternatives have to be computed.

\subsection{Maximisation of the digestible ( $\mathrm{i} n$ $\mathrm{i}$ t $\mathrm{r}$ o) dry-matter yield}

The maximization of the dry-matter yield presented earlier does not provide the farmer with enough information, in its present form, about the actual optimum. The attainment of an ordinary dry-matter yield which is as large as possible is not sufficient for him: he judges it also by the quality of the yield that he harvests. Since Italian ryegrass is usually harvested as silage for ruminants, the farmer is more interested in maximising only that portion of the dry-matter yield which the ruminant is capable of utilizing, i.e. the so-called digestible dry-matter yield.

Nowadays the rapidly determinable in vitro digestibility (TILLEY and TERRY 1963) is used as an indicator of the digestibility. The previously mentioned method for determining the optimum cutting schedule is also suitable for maximising the digestible dry-matter yield. The yield obtained in the cutting is merely multiplied by some weighting function which has a value dependant on the quality of the silage, for example between $0-1$. The weight. ing can be carried out directly with the in vitro digestibility. The optimum 
cutting schedule then maximises the digestible dry-matter yield. Weighting directly with the digestibility is in practise too slight since the digestibility varies within narrow limits. Let us consider as an example two dry-matter yields, both of $5000 \mathrm{~kg} \cdot \mathrm{ha}^{-1}$, one of which has a digestibility of $60 \%$ and the other $80 \%$. The digestible dry-matter yields are thus $3000 \mathrm{~kg} \cdot \mathrm{ha}^{-1}$ and 4000 $\mathrm{kg} \cdot \mathrm{ha}^{-1}$ respectively. The yield which has a lower digestibility corresponds to three quarters of the yield with the higher digestibility when it is weighted in this way. However, the farmer considers that the yield with $60 \%$ digestibility is poorer than the previous one. Possibly he has some lower limit (at least theoretically) for the digestibility and if the value falls below this he will reject that kind of silage. When the digestibility of the silage is above this limit, then the dry-matter yield is weighted with some weighting function $U$ which depends on the digestibility according to Fig. 32 .

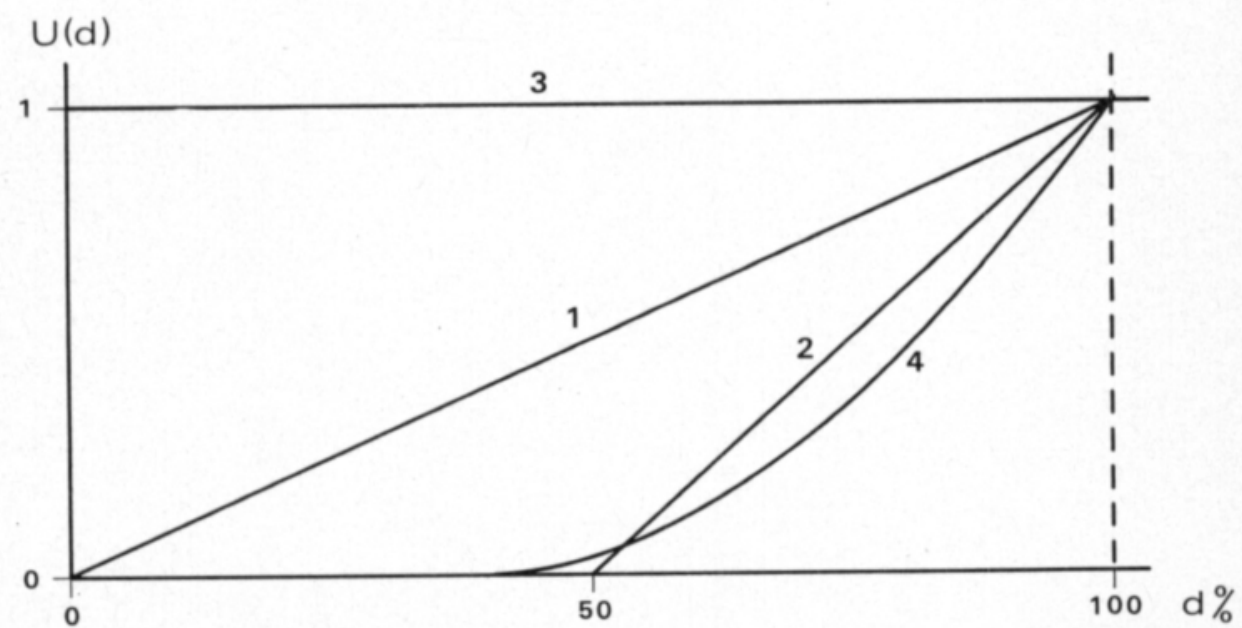

Fig. 32. A few examples of the weighting function of the dry-matter yield. 1) weighting directly with the digestibility, 2) rejection digestibility $50 \%, 3$ ) no weighting, 4) weighting function of the $2^{\text {nd }}$ degree.

Provided that the rejection digestibility is $50 \%$, as mentioned earlier, and the values between $50-100 \%$ are weighted linearly (case 2), the yield with a digestibility of $60 \%$ corresponds to only a third of the yield with the higher digestibility. This correspondence is perhaps more realistic than the previous one from the farmer's point of view.

The weighting carried out directly with the digestibility can also be seen in Fig. 32. In this case $\mathrm{U}(\mathrm{d})=\mathrm{d}$. The weighting can also be carried out in a more complicated manner, for instance by employing a second degree weighting function (case 4). The non-weighted dry-matter yield is obtained as a special case (case 3). Then $\mathrm{U}(\mathrm{d})=1$.

In grasses the digestibility of the dry-matter is an indicator of the stage of development (cf. e.g. Tilley et al. 1960-1964). It is therefore natural to examine it in the same way as was used for the dry-matter yield, namely as 


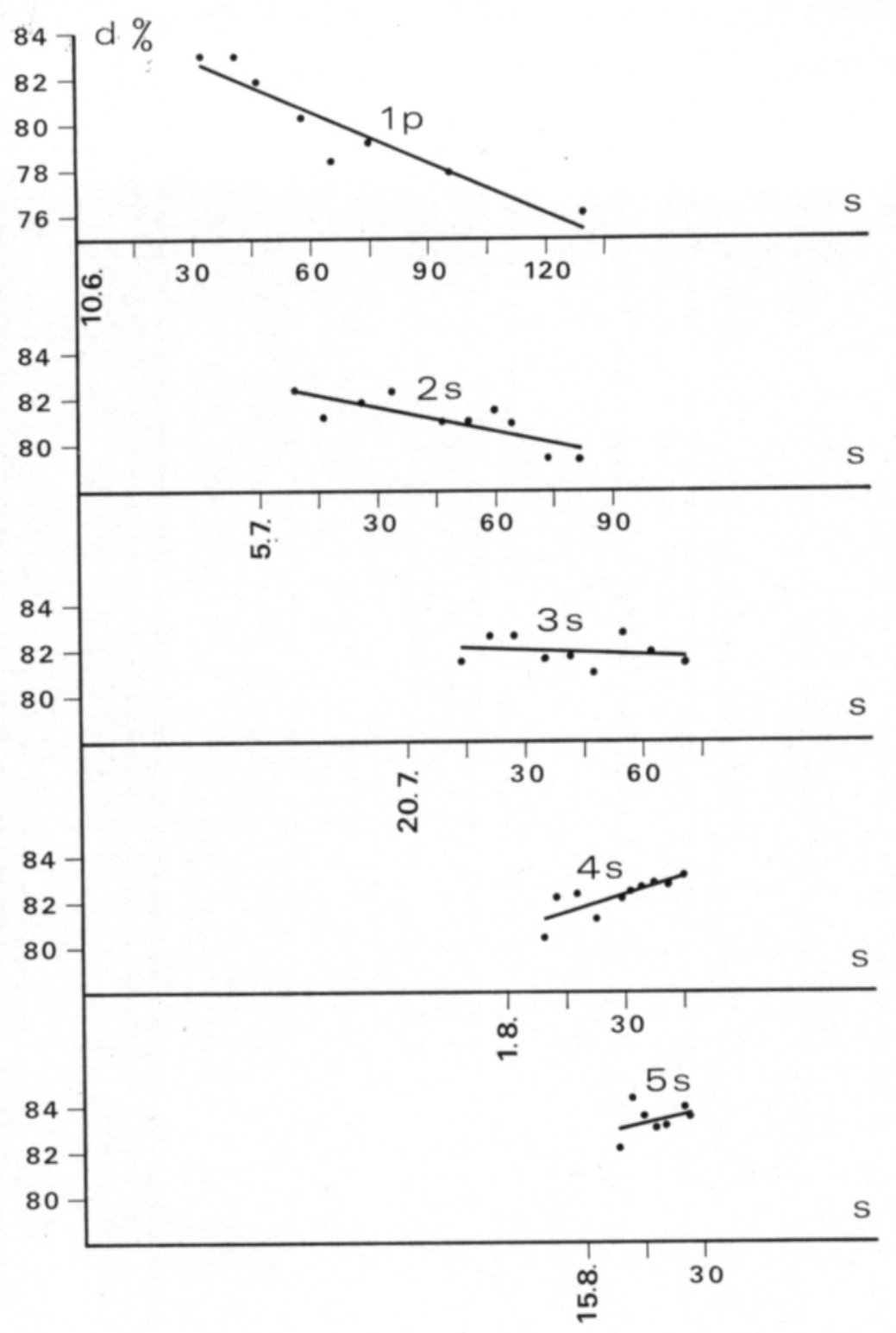

Fig. 33. The digestibility (in vitro) of the dry-matter yield of Italian ryegrass as a function of the amount of DVS of the sward in the 1973 measurement seres. $\mathrm{p}=$ primary growth, $\mathrm{s}=$ secondary growth.

a function of the amount of DVS of the sward (Fig. 33). The digestibility (d) of the dry-matter as a function of DVS can be simply depicted using a linear model

$$
\mathrm{d}=\mathrm{m} \cdot \mathrm{s}+\mathrm{b}
$$

The values of the parameters $\mathrm{m}$ and $\mathrm{b}$ depend upon which instant in the growing season is chosen as the initial instant of DVS in each sward (Fig. 34). 

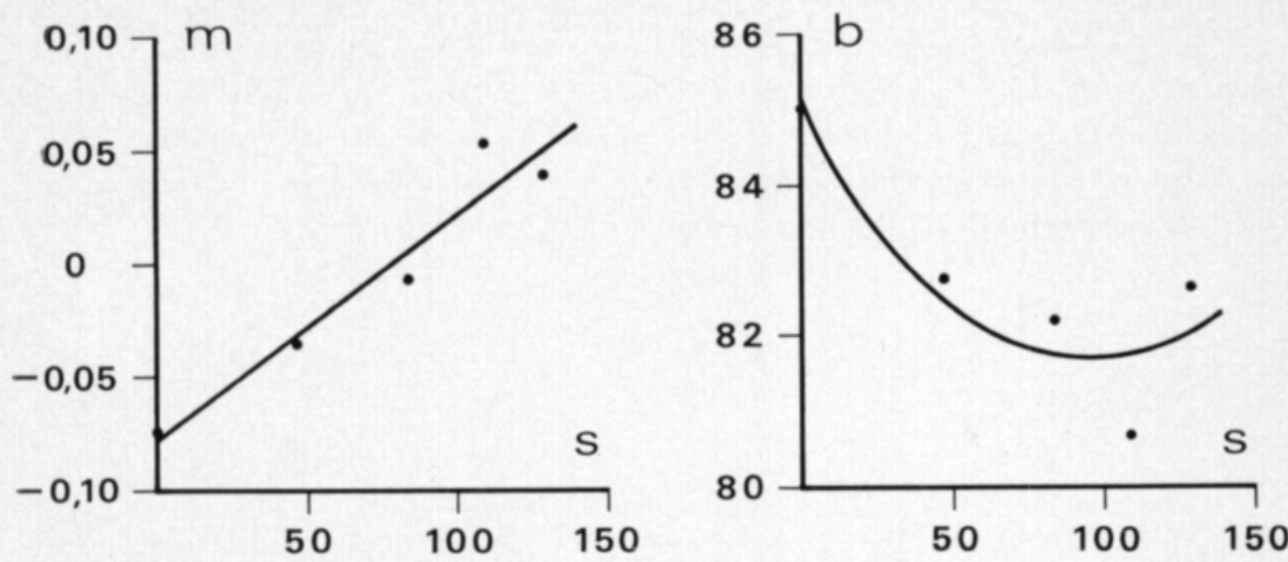

Fig. 34. Parameters $\mathrm{m}$ and $\mathrm{b}$ (Eq. 5.12) in the experimental swards located in different points inside the growing season (1973).

Let us denote the parameters $\mathrm{m}$ and $\mathrm{b}$ with vector $\mathrm{D}=(\mathrm{m}, \mathrm{b})$ (cf. vector $\mathrm{V}$ in section 4.5). The digestibility of the dry-matter obtained in the cutting depends partly on vector D and partly on the amount of DVS of the sward:

$$
\mathrm{d}=\mathrm{d}(\mathrm{D}, \mathrm{s})
$$

Let us denote the yield weighted by the digestibility of the dry-matter obtained in the cutting by $\mathrm{W}^{*}$. It is obtained by multiplying the ordinary drymatter yield $\mathrm{W}$ by the weighting function $\mathrm{U}=\mathrm{U}(\mathrm{d})$, which is dependant on the digestibility of the dry matter:

$$
\mathrm{W}^{*}=\mathrm{U} \cdot \mathrm{W}
$$

The weighting function $\mathrm{U}$ in Eq. $\mathbf{5 . 1 4}$ is dependant upon the vector $\mathrm{D}$ and the amount of DVS of the sward. Furthermore, the dry-matter yield W is dependant on the vector $\mathrm{V}$ and the amount of DVS of the sward (Eq. 5.1). The yield weighted by the digestibility of the dry-matter obtained in the cutting can thus be denoted:

$$
W^{*}=G(V, D, s)
$$

The optimum cutting schedule of the yield weighted by the digestibility of the dry-matter can be determined analogically in conjunction with the optimum cutting schedule of the ordinary dry-matter yield. The function F (Eq. 5.1) which was used in the optimization process is changed in this case into function G. Thus, for instance, the yield obtained from the primary growth $\mathrm{W}^{*}{ }_{1}$ is (cf. Eq. 5.2)

$$
\mathrm{W}_{1}^{*}=\mathrm{G}\left(\mathrm{V}_{0}, \mathrm{D}_{0}, \mathrm{~s}_{1}\right)
$$

When carrying out three cuttings for instance, the yield $\mathrm{W}^{*}{ }_{2}$ obtained in the second cutting is (cf. Eq. 5.6)

$$
\mathrm{W}_{2}=\mathrm{G}\left(\mathrm{V}\left(\mathrm{s}_{1}\right), \mathrm{D}\left(\mathrm{s}_{1}\right), \mathrm{s}_{2}-\mathrm{s}_{1}\right)
$$


The optimum cutting schedule, weighted with the digestibility of the drymatter, for Italian ryegrass to be cut twice and three times was looked for. The weighting was first carried out directly with the in vitro digestibility. The dry-matter yield was then weighted with a few linear weighting functions from Fig. 32, as the limit of the rejection digestibility was varied (Fig. 35).

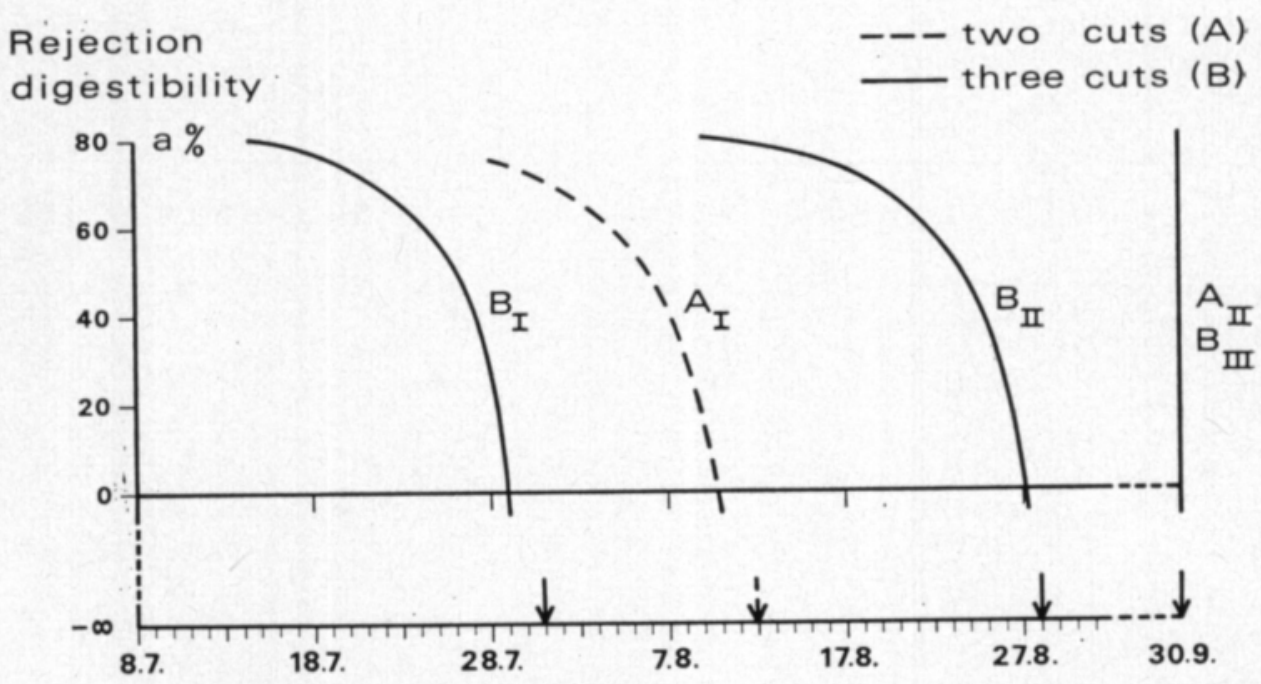

Fig. 35. Effect of weighting with dry-matter digestibility on the optimum cutting schedule of Italian ryegrass to be cut twice or three times (see text).

Decreases in the dry-matter yield resulting from changing the optimum cutting schedule and the corresponding digestibility of the silage obtained in different cuttings, when the weighting method is varied, are presented in Tables 9 and 10.

Table 9. Effect of different weighting methods (a, see text) on the digestibility (in vitro) of dry matter and the yields of Italian ryegrass cut twice. $d_{1}$ and $d_{2}=$ digestibilities in the first and second cuttings, $\mathrm{W}_{1}, \mathrm{~W}_{2}$ and $\mathrm{W}_{3}=$ the yields in the first and second cuttings, and total $\left(\mathrm{kg} \mathrm{ha}^{-1}\right)$.

\begin{tabular}{rlllll}
\hline $\mathrm{a}$ & $\begin{array}{c}\mathrm{d}_{1} \\
\%\end{array}$ & $\begin{array}{c}\mathrm{d}_{2} \\
\%\end{array}$ & $\mathrm{~W}_{1}$ & $\mathrm{~W}_{2}$ & $\mathrm{~W}_{\mathrm{t}}$ \\
\hline & 77.4 & 82.9 & 5452 & 2747 & 8199 \\
0 & 77.6 & 82.8 & 5318 & 2871 & 8189 \\
10 & 77.7 & 82.8 & 5271 & 2912 & 8183 \\
20 & 77.7 & 82.8 & 5271 & 2912 & 8183 \\
30 & 77.8 & 82.7 & 5222 & 2952 & 8174 \\
40 & 77.9 & 82.7 & 5172 & 2993 & 8164 \\
50 & 78.0 & 82.6 & 5067 & 3072 & 8139 \\
60 & 78.2 & 82.4 & 4900 & 3189 & 8089 \\
70 & 78.7 & 82.1 & 4528 & 3416 & 7945 \\
75 & 79.2 & 81.7 & 4113 & 3637 & 7749 \\
\hline
\end{tabular}


Table 10. Effect of different weighting methods (a, see text) on the digestibility (in vitro) of dry matter and the yields of Italian ryegrass cut three times. $d_{1}, d_{2}, d_{3}=$ digestibilities in the first, second and third cuttings, $\mathrm{W}_{1}, \mathrm{~W}_{2}, \mathrm{~W}_{3}, \mathrm{~W}_{\mathrm{t}}=$ the yields in the first, second and third cuttins, and total $\left(\mathrm{kg} \cdot \mathrm{ha}^{-1}\right)$

\begin{tabular}{rccccccc}
\hline a & $\begin{array}{c}\mathrm{d}_{1} \\
\%\end{array}$ & $\begin{array}{c}\mathrm{d}_{2} \\
\%\end{array}$ & $\begin{array}{c}\mathrm{d}_{3} \\
\%\end{array}$ & $\mathrm{~W}_{1}$ & $\mathrm{~W}_{2}$ & $\mathrm{~W}_{3}$ & $\mathrm{~W}_{\mathrm{t}}$ \\
\hline & 78.8 & 81.9 & 83.6 & 4459 & 2622 & 1620 & 8701 \\
0 & 79.1 & 81.8 & 83.6 & 4241 & 2751 & 1700 & 8693 \\
10 & 79.1 & 81.8 & 83.5 & 4119 & 2861 & 1700 & 8680 \\
20 & 79.2 & 81.7 & 83.5 & 4119 & 2784 & $1779 \cdot$ & 8682 \\
30 & 79.2 & 81.7 & 83.5 & 4119 & 2784 & 1779 & 8682 \\
40 & 79.3 & 81.7 & 83.5 & 3985 & 2830 & 1849 & 8665 \\
50 & 79.5 & 81.6 & 83.5 & 3985 & 2769 & 1907 & 8661 \\
60 & 79.8 & 81.5 & 83.4 & 3611 & 3020 & 1970 & 8602 \\
70 & 80.3 & 81.3 & 83.3 & 3040 & 3160 & 2261 & 8461 \\
75 & 80.8 & 81.2 & 83.2 & 2617 & 3260 & 2458 & 8335 \\
\hline
\end{tabular}

\subsection{Discussion}

The optimum cutting schedule of Italian ryegrass was determined for a theoretical ley, the yield of which was calculated with the aid of a growth model constructed on the basis of development and crop growth rate studies. This model is exceedingly specific: almost all of the information about the ley required for optimization is included on the one hand in the vector V (Eq. 4.20) of the proper growth rate and on the other hand in the vector D (Eq. 5.13) of the digestibility of the dry-matter. As a matter of fact, the model itself can only be used to depict the behaviour of a certain ley under certain conditions. For this reason the optimum cutting schedule should be considered primarily as an analysis technique which can be used to approach the problem of the maximization of the total yield under certain conditions. When examining the results of optimization it should be kept in mind that the results are not observations taken directly from the actual situation in the field, but rather observations concerning the behaviour of a greatly simplified model. The degree to which the results given by the model correspond to the field observations, or is the model a sufficiently accurate idealisation for the actual situation, can only be verified by means of field experiments.

Calculation of the optimum cutting schedule using the gradient method was found to be fast and flexible. The same computer program, with slight modifications, could be used to calculate the best number of cuttings, the maximum total yield weighted by the quality of the silage or unweighted, and the optimum cutting schedule. The calculation was based on the substitution of chronological time by the development stage of the sward. The method thus becomes more abstract and maybe somewhat laborious to follow up, but the computation becomes correspondingly more simple. At the same time the optimum cutting schedule becomes fixed to the weather conditions prevailing during the growing season. 
When the optimum cutting schedules were calculated, the total yield, both weighted and unweighted, which was obtained from three cuttings was greater than that obtained from two cuttings. This is quite opposite to the observed situation in perennial swards where the largest total dry-matter yield from swards under Finnish conditions is obtained from two cuttings only (e.g. Raininko 1968). The differences between cutting twice and three times were however quite small, at their greatest about $500 \mathrm{~kg} \cdot \mathrm{ha}^{-1}$ (approx. $6 \%$ of the total dry-matter yield). It would be difficult to verify the significance of such small differences in ordinary field experiments. In addition it should be remembered that optimization does not include any information about possible mechanical and physiological damage to the sward incurred in connection with the cuttings. This effect may possibly decrease the total yield as the number of cuttings increases.

An obvious trend in the results was that the cuttings were concentrated in the latter half of the growing season. This concentration was stronger, the slighter was the weighting of the dry-matter yield. The first cutting date was chosen at the end of July or the beginning of August. As a result, a greater yield was obtained in the first cutting than in the others. Therefore when growing Italian ryegrass it is not worth trying to obtain yields of similar size in each of the cuttings (cf. HuOKuna 1964). As we are concerned here with an annual grass, the primary growth should be given enough time to tiller and consolidate its root system before the first cutting is carried out. The growth potential of the aftermath will thus be exploited to the full (cf. p. 109). The optimum cutting schedule calculated with the model probably allows the primary growth too much time for growth. This question should be considered by setting up field experiments.

When the dry-matter yield was weighted directly with the digestibility of the dry-matter, the dates of the optimum cutting schedule were moved back only one or two days earlier than those obtained in the optimization of the total dry-matter yield. Thus the weighting which was carried out was slight. This is further emphasised by the fact that the digestibility of tetraploid Italian ryegrass remains within quite narrow limits (Fig. 33). When the weighting was made steeper, the cutting dates as would be expected were moved backwards (Fig. 35). The result is identical to the observations made on perennial leys where it was found that the earlier the development stage at which the sward is cut, the higher is the quality of the silage (cf. e.g. Pritchard et al. 1963, Mrnson et. al. 1964, Mowat et al. 1965).

Moving the cuttings in the cutting schedules to earlier dates resulted in a slight decrease in the total dry-matter yield. This decrease was quite small and it was compensated for by an increase in the quality of the silage. The optimum cutting schedule thus fulfills the requirement of modern plant husbandry, according to which the cuttings of Italian ryegrass are to be chosen so that the yield obtained is as large and of as high a quality as possible.

The yield of the optimum cutting schedule was not sensitive to small changes in the cutting schedule. Brockington et al. (1970) came to the same conclusion when studying the maximization of the digestible dry-matter yield of a perennial ley. The unweighted or relatively lightly weighted optimum cutting schedule 
for Italian ryegrass cut three times was also interesting from the point of view of practise. It is the same as the one which has already been used in Northern Finland: the sward is to be cut at the end of July, end of August and end of September (AnTtinen 1960).

\subsection{Towards the optimum cutting schedule of Italian ryegrass}

Calculation of the optimum cutting schedule of Italian ryegrass was based on an abstract model of the crop growth rate. A study based on the use of models can be illustrated by the following diagramme (Fig. 36):

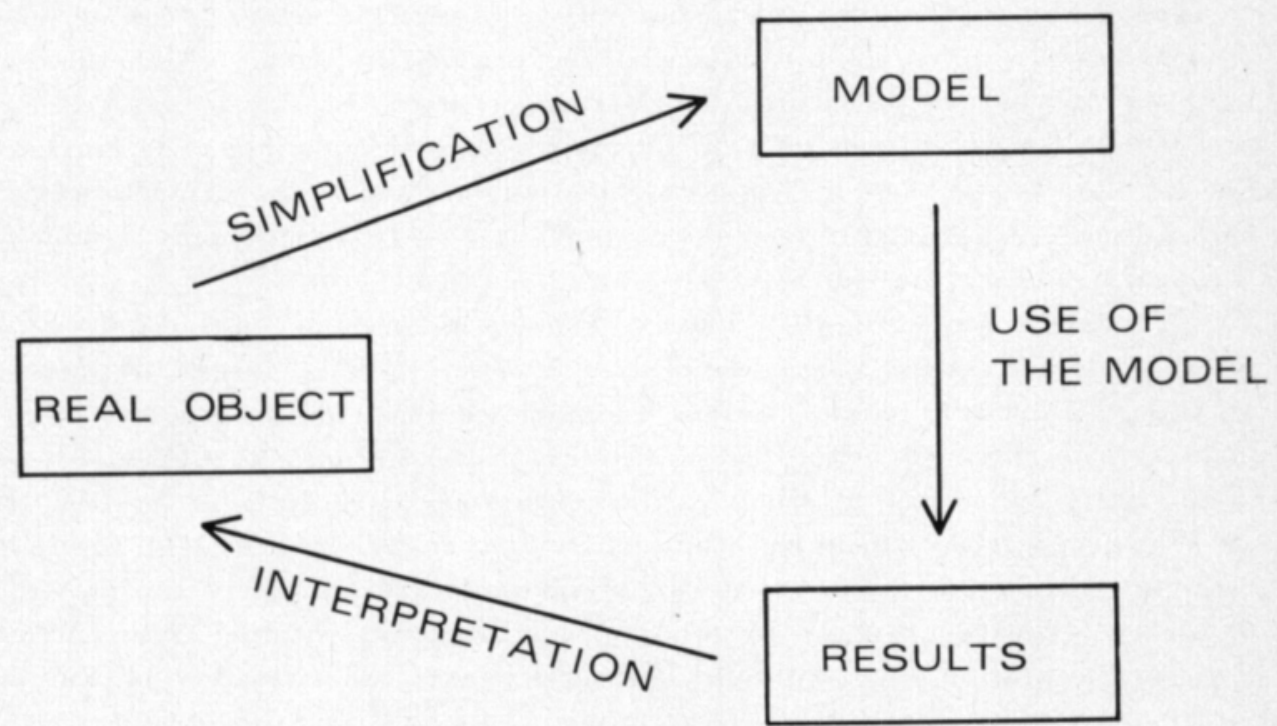

Fig. 36. Cycle of work stages in the model study (cf. Kärenlampi and Tammisola 1970).

The model study consists of three stages: the simplification of a real object to form a model, the use of the model as a certain type of mathematical experiment, and the interpretation and comparison of the results with the actual situation. When the results are interpretated, the features of the object which are the least understood are usually revealed. However, they cannot be studied using the model itself but only by means of new experiments under field conditions or in the laboratory (SPEDDING 1971, p. 195). The cyclical use of the model and the focusing studies circulate until the model is finally good enough, i.e. the object is so well understood that it can be simulated.

The model of the crop growth rate of Italian ryegrass was constructed on the basis of the height measurements taken in 1972 (POHJONEN and HARI 1973). The first experiments with the model showed that the dry-matter yield of Italian ryegrass can be simulated by means of the concepts - development rate and crop growth rate - and that temperature in addition to time is the only 
input data that can be employed when attempting to attain sufficient accuracy under the conditions prevailing in Lapland. The development rate and crop growth rate were studied in 1973 by means of height measurements and yield samples. The model constructed on the basis of these experiments turned out to be rather satisfactory although it gave an underestimate for the dry-matter yield. The field studies set up in 1974 were designed so that more precise data would be obtained about the dry-matter yield of the sward in the final stages of development. After the model has been used it is noticed that a number of details again require checking. For instance, the development rate is insufficiently known. Whether or not the day length introduces essential precision to the calculation of the development stages or whether the temperature dependance of the development rate is the same at different stages of the ontogeny should be studied. Similarly, the calculation of the proper growth rate should be adjusted by studying whether or not curves other than symmetrical logistic growth curve can be used to describe the dry-matter yield. Furthermore, the behaviour of vector $\mathrm{V}$, which describes the properties of the ley in the equation for the proper growth rate, during the growing season, should be known. Specific objects like these will appear after the model study has rotated a number of times. As a matter of fact, the circle itself must be rotated forever, unless the accuracy reached at some stage is considered to be sufficient.

The model based on the 1974 field experiments was used in the determination of the optimum cutting schedule of Italian ryegrass. Some features also arose at this stage which require further examination in field experiments. For instance, concentration of the cutting instants in the optimum cutting schedule in the latter half of the growing season is just such a feature.

When the zircle of the model study has rotated enough it can finally be used to simulate the growth of a cultivated Italian ryegrass, namely the growth of the one growing on peat soil under specific conditions at the Arctic Circle Experiment Station. An optimum cutting schedule can obviously be found for it with a relative good degree of accuracy. Although a number of generalizations can already be made on the basis of this ley about leys growing under corresponding cultivation conditions, some studies on the significance of different soil types, different moisture conditions, different varieties etc. in the computation of an optimum cutting schedule have still to be carried out before optimum cutting schedules intended for practical cultivation can be presented. These stages however are only adjustments because the optimization method presented in this study is also suitable for studying these features.

It should be kept in mind that the calculation of an optimum cutting schedule requires information about the weather conditions prevailing during the growing season. Cutting recommendations can only be given for the forthcoming growing season with any degree of certainty if it is possible to predict in advance the coming weather conditions sufficiently accurately.

In this study, the total dry-matter yield was first maximised using the optimum cutting schedule, followed by the total yield weighted with the digestibility of the dry-matter. Although the optimization weighted by the silage quality reflects more accurately the actual situation, than the maximization of the total dry-matter yield alone, it still does not represent the optimum which 
the farmer requires. He includes the economical features in the computation as well. For instance, he weighs the number of cuttings against the resulting costs. The optimum cutting schedule as far as the farmer is concerned maximises the final result in economic terms. Only when the costs are included in the computation can the real optimum cutting schedule of Italian ryegrass be approached. 


\section{Summary}

The aim of this study was to approach those bases which determine the optimum cutting schedule of Italian ryegrass (Lolium multiflorum Lam.) grown under Lapland conditions $\left(66^{\circ} 35^{\prime} \mathrm{N}\right)$ using agricultural techniques as controlled as possible. The optimum cutting schedule was defined as choosing those dates within the growing season which maximise the total yield calculated as the sum of the separate cuttings. The main principle involved in optimization is to pick the cutting dates such that the crop growth rate (CGR) (dW/dt, where $\mathrm{W}=$ biomass and $\mathrm{t}=$ time) of the sward is maintained at as high a level as possible throughout the growing season. In order to be able to put the crop growth rate into quantitative terms, the development rate of Italian ryegrass was first studied. A method was presented for the determination of its temperature dependance, which utilises only observations taken under field conditions. The measure of another time concept, DVS, which can be used to put a numerical value on the DeVelopment Stages, was calculated by means of HARI's transformation for Italian ryegrass from the development rate. A dynamic model was then formulated for the crop growth rate of Italian ryegrass in which DVS represented the essential role. The growth model was constructed as multiplicative, in which the factors were the internal state resulting from the ontogeny of the plants, and the environmental state. A new concept, the proper growth rate, PGR: increase in the dry-matter yield of the sward per unit of DVS (PGR $=\mathrm{dW} / \mathrm{ds}$ ), was defined in order to quantify the internal state. In the study, the proper growth rate measured the growth potential which is associated with the stages of development in an Italian ryegrass sward. The earlier determined development rate (M) was observed as the value of the environmental state, which was the other factor in the growth model. The cropgrowth rate model is thus $\mathrm{CGR}=\mathrm{PGR} \cdot \mathrm{M}$.

The crop growth rate of Italian ryegrass was studied at the Arctic Circle Experiment Station during 1973 and 1974. The proper growth rate was determined from primary observations as the derivative of an ordinary logistic growth curve which passes through the origin. The behaviour of the proper growth rate was studied using swards which were situated at different times during the growing season. It was found that the aftermath is only able to maintain as intensive a level of growth as possible, after cutting, when the sward which preceded it, is allowed to consolidate itself until the end of July - beginning of August. The maximum theoretical daily growth of Italian. 
ryegrass at the Arctic Circle Experiment Station was calculated, using the proper growth rate, as $300 \mathrm{~kg} \cdot \mathrm{ha}^{-1} \cdot$ day $^{-1}$.

The optimum cutting schedules for a hypothetical Italian ryegrass sward were sought using the crop growth rate model of Italian ryegrass, an experimental sward used being as a prototype. The weather data used was that collected in 1974. The digestibility (in vitro) of the dry-matter yield was used to find the optimum cutting schedule in order to maximise the total yield which has been weighted in different ways. It was noticed that to find the optimum solution it was sufficient to choose the cutting dates so that the proper growth rate was maintained at as high a level as possible throughout the growing season. An optimization method based on the gradient concept was used to determine it. The maximum yield was obtained when the sward is cut three times, and when the cuttings are concentrated into the latter half of the growing season. The primary growth had to be given enough time to tiller and consolidate its rooting system before making the first cutting, which according to the results of this study should not be carried out until the end of July. The yield of the optimum cutting schedule was not sensitive to small changes in the cutting dates. In addition, by increasing the number of cuttings from two to three the total yield was only sightly greater. From the practical point of view, the optimum cutting schedule for Italian ryegrass cut three times was also interesting. It was the same which has already been used in Northern Finland: the sward is to be cut at the end of July, the end of August and the end of September. 


\section{REFERENCES}

Aвrami, G. 1972. Optimum mean temperature for plant growth calculated by a new method of summation. Ecology 53: 893-900.

ANDERSIN, H. E. 1968. Johdatus numeerisen simuloinnin käyttōôn yrityssysteemien suunnittelussa. Konekirjoite. Valtion tietokonekeskus.

Antrinen, O. 1960. Italian raiheinää koskevia koetuloksia ja kokemuksia. Suomen laiduntalous 32: $51-55$.

Blackman, V. H. 1919. The compound interest law and plant growth. Ann. Bot. 33: 353-360.

Brockington, N. R., Radford, P. J. \& Corrall, A. J. 1970. Defoliation regime and grass production. Rep. Grassl. Res. Inst. 1970. p. 113.

Brougham, R. W. \& Glenday, A. C. 1967. Grass growth in midsummer: A re-interpretation of published data. J. Br. Grassl. Soc. 22: 100-107.

Cleary, B. D. \& Waring, R. H. 1969. Temperature: collection of data and its analysis for the interpretation of plant growth and distribution. Can. J. Bot. 47: 167-173.

CoOPER, J. P. 1966. The use of physiological variation in forage-grass breeding. The growth of cereals and grasses. p. 293-307. London.

- - \& Breese, E. L. 1971. Plant breeding: forage grasses and legumes. Potential crop production. p. 295-318. London.

Cramer, H. 1945. Mathematical methods of statistics. 575 p. Uppsala.

Cross, H. Z. \& ZUBER, M. S. 1972. Prediction of flowering dates in maize based on different methods of estimating thermal units. Agron. J. 64: 351-355.

DAнL, E. \& MоRк, E. 1959. Om sambandet mellom temperature, ånding og vekst hos gran (Picea abies (L.) Karst.) Meddel. fr. Norske Skogsforsøksvesen 53: 81-93.

Davidson, J. L. \& MrLthorpe, F. L. 1965. Carbohydrate reserves in the regrowth of cocksfoot (Dactylis Glomerata L.). J. Br. Grassl. Soc. 20: 15-18.

DemrNg, W. E. 1948. Statiscal adjustment of data. 261 p. New York.

Evans, L. T. 1963. Extrapolation from controlled environments to the field. Environmental control of plant growth. p. 421-435. London.

- -1970 . Controlled environments in analysis of photosynthetic characteristics. Proc. IBP/PP Tech. Meeting: Prediction and measurement of photosynthetic productivity. p. 421-426. Wageningen.

- - 1975. The physiological basis of crop yield. Crop physiology. p. 327-355. Cambridge.

Evans, H. J. \& Savage, J. R. K. 1959. The effect of temperature on mitosis and the action of colchicine in root meristem cells of Vicia faba. Exp. Cell Res. 18: 51-61.

Fletcher, R. I. 1974. The quadric law of damped exponential growth. Biometrics 30: 111124.

Hari, P. 1968. A growth model for a biological population, applied to a stand of pine. Comm. Inst. For. Fenn. 66, 7.

- - 1972. Physiological stage of development in biological models of growth and maturation. Ann. Bot. Fennici 9: 107-115.

— - , LeıkolA, M. \& RÄsÃNen, P. 1970. A dynamic model of the daily height increment of plants. Ann. Bot. Fennici 7: 375-378.

- $-\&$ Siren, G. 1972. Influence of some ecological factors and the seasonal stage of development upon the annual ring width and radial growth index. Skogshögskolan, Inst f. Skogsföryngring: Rapp. och Upps. 40. 
Hillier, F. S. \& Lieberman, G. J. 1968. Introduction to operations research. 639 p. San. Francisco.

Huокuna, E. 1964. The effect of frequency and height of cutting on cocksfoot swards. Ann. Agric. Fenn. 3, Suppl. 4: 1-83.

Jones, J. G. W. 1970. Introduction. Proc. of a symposium on the use of models in agricultural and biological research, Hurley 1969.

Kavanagh, A. J. \& Richards, O. W. 1934. The autocatalytic growth curve. Amer. Nat. 68: $54-59$.

Kish, A. J., Ogle, W. L. \& Loadholt, C. B. 1972. A prediction technique for snap bean maturity incorporating soil moisture with the heat unit system. Agr. Meteorol. 10: 203209.

Kornher, A. 1971. Untersuchungen zur Stoffsproduction von Futterpflanzenbeständen. I. Acta Agric. Scand. 21: 215-236.

Kvet, J., Ondok, J. P., Necas, J. \& Jarvis, P. G. 1971. Methods of growth analysis. Plant photosynthetic production. p. $343-391$. The Netherlands.

Kärenlampi, L. \& TAmmisola, J. 1970. Ekosysteemianalyysi ja tuottavuus. Luonnon Tutkija $74: 106-112$.

Manninen, J. \& Salmi, T. 1974. Matemaattinen optimointi - teoriaa ja tekniikkaa. Kauppakorkeakoulun Julk. C: I: 25.

Mederski, H. J., Miller, M. E. \& Weaver, C. R. 1973. Accumulated heat units for classifying corn hybrid maturity. Agron. J. 65: 743-747.

MELA, T. 1974. Growth and herbage quality of meadow fescue (Festuca pratensis Huds.) under different weather conditions. Ann. Agric. Fenn. 13: 119-124.

Milthorpe, F. L. \& Moorby, J. 1974. An introduction to crop physiology. 202 p. Cambridge.

Minson, D. J., Harris, C. E., Raymond, W. F. \& Milford, R. 1964. The digestibility and voluntary intake of S22 and H.1 ryegrass, S170 tall fescue, S48 timothy, S215 meadow fescue and germinal cocksfoot. J. Br. Grassl. Sos. 19: 298-305.

Monteith, J. L. \& Elston, J. F. 1971. Microclimatology and crop production. Potential crop production. p. 23-42. London.

Mowat, D. M., Fulkerson, R. S., Tossell, W. E. \& Winch, J. E. 1965. The in vitro digestibility and protein content of leaf and steam portions of forages. Can. J. Pl. Sci. 45: $321-331$.

ОNDок, J. P. 1971. Indirect estimation of primary values used in growth analysis. Plant photosynthetic production. p. $392-411$. The Netherlands.

Pearl, R. \& ReEd. L. J. 1920. On the growth of the population of the United States since 1790 and its mathematical representation. Proc. Nat. Acad. Sci. U.S. 6: 275-288.

Pohjonen, V. \& Hari, P. 1973. A dynamic model of Crop Growth Rate of Italian ryegrass after cutting. Acta Agric. Scand. 23: 121-126.

Pritchard, G. C., Folkins, L. P. \& Pigden, W. J. 1963. The in vitro digestibility of whole grasses and their parts at progressive stages of maturity. Can. J. Pl. Sci. 43: 79-87.

RADFORD, P. J. 1967. Growth analysis formulae - their use and abuse. Crop Sci. 7: 171-175.

Raininko, K. 1968. The effects of nitrogen fertilization, irrigation and number of harvesting upon leys established with various seed mixture. Acta Agr. Fenn. 112.

- - 1970. Vihantarehukasvit. Siemenjulkaisu 1970: 112-115.

Raulo, J. \& Leiкola, M. 1974. Tutkimuksia puiden vuotuisen pituuskasvun ajoittumisesta. Comm. Inst. For. Fenn. 81, 2.

Robertson, T. B. 1929. The nature of the factors which determinate the sequence of growth cycles and its relationships to the differentiation of tissues. J. Gen. Physiol. 12: 329344.

Sarvas, R. 1970. The annual development cycle of forest trees. Proc. IUFRO Section 22, Working group meeting on the sexual reproduction of forest trees, Finland 1970.

--1972 . Investigations on the annual cycle of development of forest trees. Comm. Inst. For. Fenn. 76, 3.

Sсніевцiсн, J. 1956. Futterpflanzen Neuzuchtung. 2. Einjähriges Weidelgras. Dtsch. Landw. 7: $326-329$. 
SuroneN, M. 1972. Dynaaminen malli metsikön optimihakkuuohjelman määrittämiseksi. Helsingin yliopiston metsånarvioimistieteen laitos. Tiedonantoja 2.

Spedding, C. R. W. 1971. Grassland ecology. 221 p. Oxford.

SPIEGEL, M. R. 1959. Vector analysis. 225. New York.

SteWARD, F. C. 1968. Growth and organization in plants. 564 p. Reading.

StreEt, H. E. \& ÖPIK, H. 1970. The physiology of flowering plants: their growth and development. 263 p. London.

Tilley, J. M. A. \& Terry, R. A. 1963. A two-stage technique for the in vitro digestion of forage crops. J. Br. Grassl. Soc. 18:104-111.

- - , Terry, R. A., Deriaz, R. E. \& Outen, G. E. 1960-1964. Studies of herbage digestibility using the in vitro method. Exp. in progress, GRI, 14: 56-58, 16: 64-67, 17: $63-64$.

UTAAKER, K. 1968. A temperature growth index - the respiration equivalent - used in climatic studies on the mesoscale in Norway. Agr. Meteorol. 5: 351-359.

Watson, D. J. 1952. The physiological basis of variation in yield. Adv. Agron. 4: 101-145.

-1971 . Size, structure, and activity of the productive system of crops. Potential crop. production. p. 76-88. London.

Went, F. W. 1948. Thermoperiodicity. Vernalization and photoperiodism. p. 145-147. Chronica Botanica, Waltham, Mass.

Verhulst, P. F. 1838. Notice sur la loi que la population suit dans accroissement. Corres. Math. et Physique 10:113-121.

Wrllrams, G. D. V. 1974. Deriving a biophotothermal time scale for barley. Int. J. Biometeorol. 18: $57-69$.

Wri, C. T. de 1970. Dynamic concepts in biology. Proc. of a symposium on the use of models in agricultural and biological research, Hurley 1969.

- - \& Brouwer, R. 1968. Uber ein dynamisches Modell des vegetativen Wachstums von Pflanzenbeständen. Angew. Bot. 42:1-12.

- - - Brouwer, R. \& Penning de Vries, F. W. T. 1970. The simulation of photosynthetic systems. Proc. IBP/PP Tech. Meeting: Prediction and measurement of photosynthetic productivity. p. 47-70. Wageningen.

,-- , Brouwer, R. \& Penning de Vries, F. W. T. 1971. A dynamic model of plant and crop growth. Potential crop production. p. 117-142. London.

Wix, F. 1958. Tetraploid Italian ryegrass (Lolium multiflorum Lam.). Stichting voor Planteveredeling Meded. 19: 47-58. 


\section{APPENDICES}

Appendix 1. Fitting the curves to the primary observations (see Brougham and GLENDAY 1967).

An exponential dependance caused by tillering exists between the height of the sward and the dry-matter yield. The curve to be fitted has the form $W=Q \cdot\left(e^{C \cdot h}-1\right)$, where $h$ is the cumulative height increment of the measurement series counting from the start of the measurement series and $\mathrm{W}$ is the dry-matter yield. The values of parameters $\mathrm{Q}$ and $\mathrm{C}$ are to be found which minimise the following sum of squares:

$$
\mathrm{E}=\Sigma\left(\mathrm{W}_{\mathrm{j}}-\mathrm{Q} \cdot\left(\mathrm{e}^{\mathrm{C} \cdot \mathrm{h}_{\mathrm{j}}}-1\right)\right)^{2}
$$

$\mathrm{Q}$ and $\mathrm{C}$ are found using the following iterative procedure:

(1) Find first approximations: $Q_{1}, C_{1}$

(2) Write: $\mathrm{F}=\mathrm{W}+\mathrm{Q}-\mathrm{Q} \cdot \mathrm{e}^{\mathrm{C} \cdot \mathrm{h}}$

(3) Calculate $\mathrm{FQ}(\mathrm{j})=\partial \mathrm{F} / \partial \mathrm{Q}=1-\mathrm{e}^{\mathrm{C} \cdot \mathrm{h}(\mathrm{j})}$

$$
\begin{aligned}
& F C(j)=\partial F / \partial C=-Q \cdot e^{C \cdot h(j)} \cdot h(j) \\
& F(j)=W(j)+Q-Q \cdot e^{C \cdot h(j)}
\end{aligned}
$$

at each observed point $(\mathrm{h}, \mathrm{W})$ for $Q_{1}, C_{1}$

(4) Form the normal equations:

$$
\begin{aligned}
& \Sigma F Q(j)^{2} \cdot y+\Sigma F Q(j) \cdot F C(j) \cdot z=\Sigma F Q(j) \cdot F(j) \\
& \Sigma F C(j) \cdot F Q(j) \cdot y+\Sigma F C(j)^{2} \cdot z=\Sigma F C(j) \cdot F(j)
\end{aligned}
$$

(5) Solve for (y) and (z)

(6) Second approximations to $\mathrm{Q}$ and $\mathrm{C}$ are given by:

$$
\begin{aligned}
& Q_{2}=Q_{1}-y \\
& C_{2}=C_{1}-z
\end{aligned}
$$

(7) Continue from point (3). The process converges to the required parameters of the fitted curve.

FORTRAN program used in the earlier presented curve fitting is available from the Department of Plant Husbandry, University of Helsinki. 
The following notations are used (enclosed figure):

- The old cutting schedule at point $A=\left(s_{1}(A), s_{2}(A)\right)$.

- The new cutting schedule at point $B=\left(s_{1}(B), s_{2}(B)\right)$, such that point $B$ is at the distanceof the norm of the gradient vector in the direction of the gradient from point $A$.

- For point $A$, the radius vector $O A=s_{1}(A) \cdot i+s_{2}(A) \cdot j$

- For point $B$, the radius vector $O B=s_{1}(B) \cdot i+s_{2}(B) \cdot j$

- The total dry-matter yield to be maximised $\mathrm{W}_{\mathrm{t}}=\mathrm{W}_{\mathrm{t}}\left(\mathrm{s}_{1}, \mathrm{~s}_{2}\right)$.

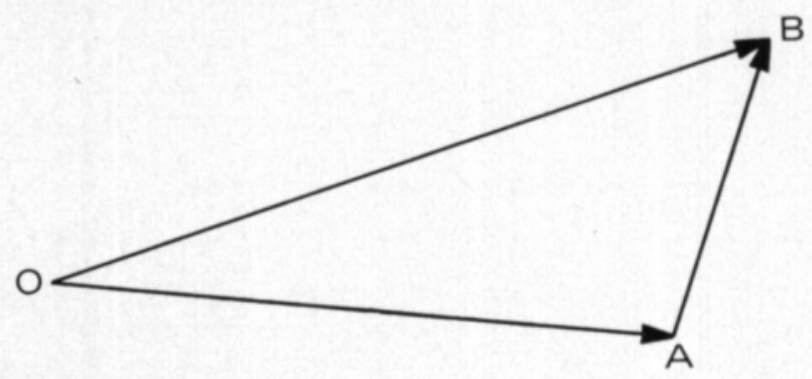

Let us calculate the gradient vector $\mathrm{AB}$ :

(1) direction of the gradient: $\partial \mathrm{W}_{\mathrm{t}} / \partial \mathrm{s}_{1} \cdot \mathrm{i}+\partial \mathrm{W}_{\mathrm{t}} / \partial \mathrm{s}_{2} \cdot \mathrm{j}$

(2) length of the gradient vector sdr (directional derivative in the direction of the gradient)=

$$
\sqrt{\left(\partial \mathrm{Wt} / \partial \mathrm{s}_{1}\right)^{2}+\left(\partial \mathrm{Wt} / \partial \mathrm{s}_{2}\right)^{2}=\mathrm{sdr}}
$$

(3) the gradient vector AB:

$$
A B=\frac{\partial W_{t}^{\prime} / \partial s_{1} \cdot i}{s d r}+\frac{\partial W_{t} t / \partial s_{2}}{s d r} \cdot j
$$

It can be seen from the figure that $\mathrm{OB}=\mathrm{OA}+\mathrm{AB}$.

Let us place the vectors $\mathrm{OA}$ and $\mathrm{AB}$ in this equation:

$$
\begin{aligned}
& O B=s_{1}(A) \cdot i+s_{2}(A) \cdot j+\frac{\partial W_{t} / \partial s_{1}}{s d r} \cdot i+\frac{\partial W_{t} / \partial s_{2}}{s d r} \cdot j \\
& O B=\left[s_{1}(A)+\frac{\partial W_{t} / \partial s_{1}}{s d r}\right] \cdot i+\left[s_{2}(A)+\frac{\partial W_{t} / \partial s_{2}}{s d r}\right] \cdot j
\end{aligned}
$$

The coordinates of point $B$ (the new cutting schedule) are obtained from vector OB:

$$
\begin{aligned}
& s_{1}(B)=s_{1}(A)+\frac{\partial W_{t} / \partial s_{1}}{s d r} \\
& s_{2}(B)=s_{2}(A)+\frac{\partial W_{t} / \partial s_{2}}{s d r}
\end{aligned}
$$

The next cutting schedule at point $\mathrm{C}$ can be calculated using the same method. The procedure is repeated until the maximum dry-matter yield is reached. When necessary, the length of the step can be changed by multiplying sdr by some constant.

The method can be analogically generalized for more than three cuttings. Using the earlier described method the maximum is not found precisely, but only comes close to it. The valueof sdr, which approaches nought, for instance can be used as the stopping criterion of the iteration.

FORTRAN program used in the earlier presented optimization is available from the Department of Plant Husbandry, University of Helsinki 


\section{Dynaaminen malli Italian raiheinänurmen optiminiittoaikataulun määrittä- miseksi}

\section{Helsingin yliopiston kasvinviljelytieteen laitos}

Tämän tutkimuksen tarkoitus oli lähestyä niitä perusteita, jotka mäăräăvät Lapin oloissa kasvavan viljelyteknisesti mahdollisimman vakioidun Italian raiheinän (Lolium multiflorum Lam.) optiminiittoaikataulun. Optiminiittoaikatauluksi nimitettiin sitä niittojen ajoittumista kasvukauteen, joka maksimoi eri niitoista yhteenlasketun kokonaiskuiva-ainesadon. Optimoinnin pääperiaate on valita niittoajankohdat siten, että nurmen kasvunopeus (CGR $=\mathrm{dW} / \mathrm{dt}$, missä $\mathbf{W}=$ biomassa ja $t=$ aika) pysyy kasvukauden ajan mahdollisimman suurena. Kasvunopeuden kvantifioimiseksi tutkittiin ensin Italian raiheinän kehitysnopeutta. Sen lämpōtilariippuvuuden määrittämiseksi esitettiin menetelmä, jolla havainnot voidaan tehdä suoraan kenttäoloissa. Kehitysnopeudesta Italian raiheinälle laskettiin HARIn muunnoksella lämpötilan ja ajan yhdistävä kehitysvaiheen mittaluku (s). Seuraavaksi Italian raiheinän kasvunopeudelle formuloitiin dynaaminen malli, jossa kehitysvaihe oli keskeinen elementti. Kasvunopeuden malli rakennettiin multiplikatiiviseksi, jossa tekijöinä olivat kasvien yksilönkehityksestä johtuva sisäinen tila sekä ympäristön tila. Sisäisen tilan laskemiseksi määriteltiin käsite ominaiskasvunopeus PGR (Proper Growth Rate) kasvuston massan mutoksena pientä kehitysvaiheen lisäystä kohti (PGR $=\mathrm{dW} / \mathrm{ds})$. Ominaiskasvunopeus mittasi tutkimuksessa kasvupotentiaalia, joka liittyi Italian raiheinän kasvuston eri kehitysvaiheisiin. Kasvunopeuden mallin toisen tekijän ympäristön tilan mittaluvuksi havaittiin aikaisemmin määritelty kehitysnopeus (M). Kasvunopeuden malli on siten CGR $=\mathrm{PGR} \cdot \mathrm{M}$.

Italian raiheinän kasvunopeutta tutkittiin vuonna 1973 ja 1974 Lapin koeasemalla. Ominaiskasvunopeus määritettiin primäärihavainnoista origon kautta kulkevan logistisen kasvukäyrän derivaattana. Ominaiskasvunopeuden käyttäytymistä tutkittiin eri aikaan kasvukautta sijoittuneissa kasvustoissa (kuvat 22 ja 25). Havaittiin, että odelma pystyi mahdollisimman intensiiviseen kasvuun vasta, kun sitä edeltänyt kasvusto oli saanut vahvistua heinä-elokuun vaihteeseen. Ominaiskasvunopeuden avulla laskettiin teoreettinen Italian raiheinän päivittäisen kasvun maksimi Lapin koeasemalla: n. 300 kg·ha-1. $\mathbf{v r k}^{-1}$.

Italian raiheinän kasvunopeuden mallin avulla etsittiin optiminiittoaikatauluja hypoteettiselle Italian raiheinänurmelle, jonka esikuvana oli tutkimuksissa Lapin koeasemalla käytetty nurmi. Säätietoina käytettiin vuoden 1974 havaintoja. Optiminiittoaikatauluja etsittiin sekä kokonaiskuiva-ainesadon että kuiva-aineen sulavuudella (in vitro) eri tavoin painotetun kokonaissadon maksimoimiseksi (kuvat 28, 31 ja 35, taulukot 6 ja 7). Optimiratkaisun löytämiseksi havaittiin riittävän, jos niitot ajoitetaan siten, että ominaiskasvunopeus pysyy kasvukauden ajan mahdollisimman suurena. Optiminiittoaikataulun löytämiseksi käytettiin gradientin käsitteeseen perustuvaa optimointimenetelmää. Maksimaalinen sato havaittiin saatavan, kun kasvusto niitetään kolme kertaa. Niittojen havaittiin keskittyvän kasvukauden loppupuolelle. Primäärikasvuston oli annettava riittävästi pensastua ja sen juuriston vahveta ennen ensimmäistä niittoa. Optiminiittoaikataulun tuottama sato ei ollut herkkä pienille niittoaikataulun muutoksille. Myös niittojen lukumäärän nostamisella kahdesta kolmeen oli vain vähäinen vaikutus kokonaissatoon. Käytännön kannalta mielenkiintoinen oli myös kolmesti niitettävän Italian raiheinän optiminiittoaikataulu. Se oli sama, mitä Pohjois-Suomessa on jo käytetty: kasvusto on niitettävä heinåkuun lopussa, elokuun lopussa ja syyskuun lopussa. 